\title{
Water Scarcity: Problems and Possible solutions
}

\author{
Nadhir Al-Ansari', Nahla Abbas ${ }^{2}$, Jan Laue ${ }^{3}$ and Sven Knutsson ${ }^{4}$
}

\begin{abstract}
Iraq relies in its water resources on the Rivers Tigris and Euphrates and their tributaries. It used to be considered rich in its water resources until 1970. Then, the water quantity started to decrease due to the construction of hydrological projects within the riparian countries as well as the effect of climate change. In addition, water management planning in Iraq requires number of strategies that can help to overcome the water shortage problem. In this work, the negative problems are discussed and solutions are given to solve the water shortage problem.
\end{abstract}

Keywords: Water Scarcity, Tigris, Euphrates, Climate Change, Iraq.

${ }^{1}$ Lulea University of Technology, Sweden.

2 CQUniversity Australia.

${ }^{3}$ Lulea University of Technology, Sweden.

${ }^{4}$ Lulea University of Technology, Sweden.

Article Info: Received: October 27, 2020. Revised: November 1, 2020.

Published online: November 15, 2020. 


\section{Introduction}

The Euphrates River catchment area in Turkey is about $125,000 \mathrm{~km}^{2}(28.2 \%)$, while it is only $7,600 \mathrm{~km}^{2}(17.1 \%)$ in Syria and the remainder $177,000 \mathrm{~km}^{2}(39.9 \%)$ is in Iraq. It should be mentioned, however, that part of the catchment of the river lies in Saudi Arabia $\left(66,000 \mathrm{~km}^{2}\right)$, but it does not supply any water to the river except when precipitation takes place in that area which is very rare.

High discharges of the Euphrates River take place usually during March-June period where about $63 \%$ of the annual flow passes through that period. The minimum flow period is July and August. During flood time, the river carries a huge amount of sediments (Al-Ansari et.al., 1988). Elhance (1999) stated that generally the amount of sediments that is carried by the Euphrates in one day can cover an area of 600 acres with a layer $0.25 \mathrm{~cm}$ thick. This in fact, how the Mesopotamian plain was formed.

The Tigris River is $1,718 \mathrm{~km}$ long and its drainage area is $235,000 \mathrm{~km}^{2}$ distributed between 4 countries as follows: Turkey 17\%, Syria 2\%, Iran 29\% and Iraq 52\% (Figure 1). The river rises near lake Hazar in southeast Turkey. It runs toward the Turkish-Syrian border and forms the border between these countries for about $45 \mathrm{~km}$, then it enters Iraq $4 \mathrm{~km}$ north Fieshkhabur near Zakha city. During its course in Iraq 5 main tributaries join the main river. These are Khabur, Greater Zab, Lesser Zab, Adhaim and Diyala (Figure 1). Most of these tributaries rise from Zagros mountain range. They carry snow melt and rainfall and for this reason, depending on the phasing of these two types of flows, the flow varies greatly within the Tigris. The sediments transported by the river at Baghdad vary with the discharge from 35 to 52 million tons per year (Al-Ansari and Toma, 1986; Al-Ansari and Ali, 1986). 


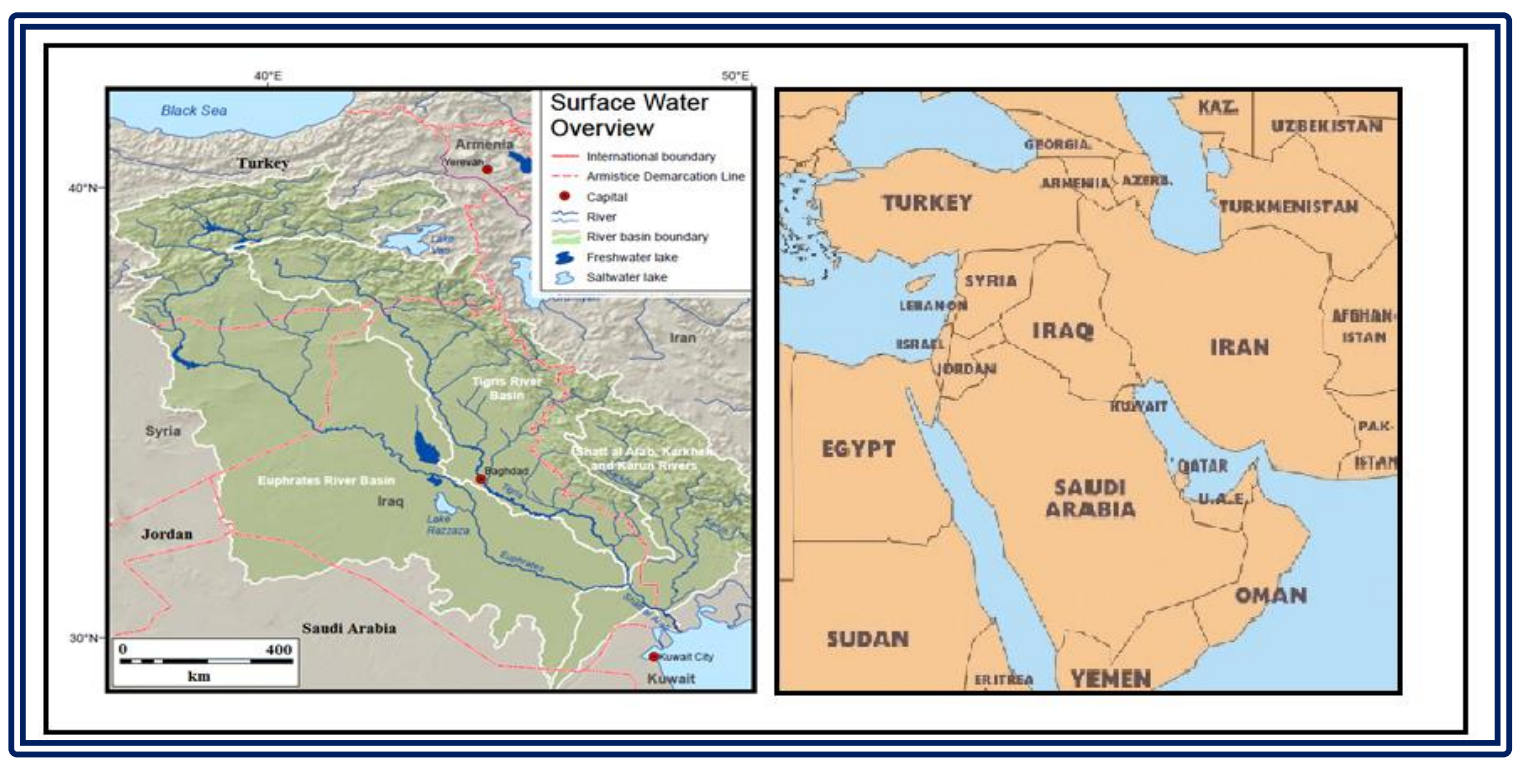

Figure 1: Tigris and Euphrates Rivers Basins (modified from ESCWA, 2013).

Flow records show great variation of the flow of the Tigris and Euphrates rivers. The flow of the former can fluctuate where the high flow can be eighty times its low flow while the latter can be twenty times its low flow (Elhance, 1999). This is attributed to climate change and construction of hydrological projects. The implications of these variations led all riparian countries to build as many dams as they could to overcome these variations and to ensure availability of water (Table 1). One of such the projects, which raised tension, is the Greater Anatolia Project (GAP). This includes 22 dams and 19 hydropower stations (Ali, 2018). The other reason for building the dams is to mitigate the effect of floods (Ravindranath et al. 2016; Najibi et al. 2017). 
Table 1: Constructed dams within Tigris, Euphrates Basins.

(source Wikipedia, 2017 a, b, c).

\begin{tabular}{|c|c|c|c|c|}
\hline Dam & River & Height (m) & Purpose & $\begin{array}{c}\text { Completion } \\
\text { Date }\end{array}$ \\
\hline \multicolumn{5}{|c|}{ IRAN } \\
\hline Dez & Shatt Al-Arab/Karun & 203 & $\mathrm{I} / \mathrm{P}$ & 1963 \\
\hline $\begin{array}{c}\text { Shahid Abbaspour } \\
\text { (Karun1) }\end{array}$ & Shatt Al-Arab/Karun & 200 & $\mathrm{P}$ & 1976 \\
\hline $\begin{array}{c}\text { Masjed Sulaayman } \\
\text { (Karun 2) }\end{array}$ & Shatt Al-Arab/Karun & 164 & $\mathrm{P}$ & 1976 \\
\hline Karun 3 & Shatt Al-Arab/Karun & 205 & $\mathrm{I} / \mathrm{P} / \mathrm{F}$ & 2002 \\
\hline Karun 4 & Shatt Al-Arab/Karun & 230 & $\mathrm{I} / \mathrm{P} / \mathrm{F}$ & 2010 \\
\hline Garan & Tigris/Diyala/Sirwan & 62 & I & 2005 \\
\hline Darayan & Tigris/Diyala/Sirwan & 169 & $\mathrm{I} / \mathrm{P}$ & 2010 \\
\hline Upper Gotvand & Shatt Al-Arab/Karun & 180 & $\mathrm{P}$ & 2012 \\
\hline Lowe Gotvand & Shatt Al-Arab/Karun & 22 & $\mathrm{P}$ & 1977 \\
\hline Karkha & Shatt Al-Arab/Karkha & 127 & $\mathrm{I} / \mathrm{P}$ & 2001 \\
\hline Seimare & Shatt Al-Arab/Karkha & 180 & $\mathrm{P}$ & 2013 \\
\hline Khersan 3 & Shatt Al-Arab/Karun/Karkha & 195 & $\mathrm{P} / \mathrm{F}$ & 2015 \\
\hline \multicolumn{5}{|c|}{$\begin{array}{r}\text { Turkey } \\
\end{array}$} \\
\hline $\begin{array}{l}\text { Çetin Dam } \\
\text { (Alkumru) }\end{array}$ & Tigris/Botan & 145 & $\mathrm{P}$ & 2016 \\
\hline Aslandā̄ & Tigris/Greater Zab/Bembo & 60 & $\begin{array}{l}\mathrm{I} / \mathrm{M} / \mathrm{P} \\
\text { (future) }\end{array}$ & 2012 \\
\hline Beyyurdu & Tigris/Greater Zab/Bembo & 48 & $\begin{array}{c}\mathrm{I} / \mathrm{M} / \mathrm{P} \\
\text { (future) }\end{array}$ & $\begin{array}{c}\text { Under } \\
\text { Construction } \\
\end{array}$ \\
\hline Atatürk (Karababa) & Euphrates & 169 & $\mathrm{P}$ & 1992 \\
\hline Balli & Tigris/Khabour /Hezil/Ortasu & 49 & $\mathrm{I} / \mathrm{M} / \mathrm{P}$ & $\begin{array}{c}\text { Under } \\
\text { Construction }\end{array}$ \\
\hline Batman & Tigris/Batman & 74 & $\mathrm{I} / \mathrm{P}$ & 1999 \\
\hline Beyhan I & Euphrates/Murat & 97 & $\mathrm{P}$ & 2015 \\
\hline Beyhan II & Euphrates/Murat & 62 & $\mathrm{P}$ & Planned \\
\hline Birecik & Euphrates & 62.5 & $\mathrm{I} / \mathrm{P}$ & 2001 \\
\hline Burḉ Bendi & Euphrates/Gö̈ksu & 47 & $\mathrm{P}$ & 2010 \\
\hline Cizre & Tigris/Botan & 46 & $\mathrm{I} / \mathrm{P}$ & Planned \\
\hline Ḉoukurca & Tigris/Greater Zab/Güzedlere & 45.5 & $\mathrm{~W} / \mathrm{M}$ & $\begin{array}{c}\text { Under } \\
\text { Construction } \\
\end{array}$ \\
\hline Dumluka & Euphrates/Bugur & 30 & $\mathrm{I}$ & 1991 \\
\hline Erkenek & Euphrates/Adiyaman & - & $\mathrm{p}$ & Operational \\
\hline Gï̈ksu & Euphrates/Gö̈ksu & 52 & $\mathrm{I}$ & 1991 \\
\hline Hecihider & Euphrates/Sehir & 42 & $\mathrm{I}$ & 1989 \\
\hline Hancaḡiz & Euphrates/- & - & I & 1988 \\
\hline Ilisu & Tigris & 135 & $\mathrm{I} / \mathrm{P} / \mathrm{F}$ & 2017 \\
\hline Upperkalekö̈y & Euphrates/Murat & 137.5 & $\mathrm{P}$ & 2017 \\
\hline Lower kalekỗy & Euphrates/Murat & 115 & $\mathrm{P}$ & Planned \\
\hline Karakaya & Euphrates & 158 & $\mathrm{P}$ & 1987 \\
\hline Karkamiș & Euphrates & 21.1 & $\mathrm{P}$ & 2000 \\
\hline Kavsaktepe & Tigris/Khabour /Hezil/Ortasu & 66 & $\mathrm{~W} / \mathrm{M}$ & $\begin{array}{c}\text { Under } \\
\text { Construction }\end{array}$ \\
\hline
\end{tabular}




\begin{tabular}{|c|c|c|c|c|}
\hline Kayacik & Euphrates/Sajur & 45 & $\mathrm{I} / \mathrm{P}$ & 2005 \\
\hline Keban & Euphrates & 207 & $\mathrm{P}$ & 1974 \\
\hline Kirazlik & Euphrates/Botan & 60 & $\mathrm{I} / \mathrm{P}$ & 2011 \\
\hline Kralkizi & Tigris/Maden & 113 & $\mathrm{I} / \mathrm{P}$ & 1997 \\
\hline Musatatepe & Tigris/Khabour/Hezil/Ortasu & 34.5 & $\mathrm{~W} / \mathrm{M}$ & $\begin{array}{c}\text { Under } \\
\text { Construction }\end{array}$ \\
\hline Silope & Tigris/Khabour /Hezil & 79.5 & W/M/P & 2012 \\
\hline Silvan & Tigris/Batman & 174.5 & $\mathrm{I} / \mathrm{P}$ & 2017 \\
\hline Sirrntiș & Tigris /Birimşe & 92 & I & 2013 \\
\hline Șirnak & Tigris/Khabour/Hezil/Ortasu & 56.8 & $\mathrm{~W} / \mathrm{M}$ & 2012 \\
\hline Uludere & Tigris/Khabour/Hezil/Ortasu & 55.5 & $\mathrm{~W} / \mathrm{M}$ & $\begin{array}{c}\text { Under } \\
\text { Construction }\end{array}$ \\
\hline \multicolumn{5}{|c|}{ Syria } \\
\hline Baath & Euphrates & 14 & $\mathrm{P}, \mathrm{I}, \mathrm{F}$ & 1988 \\
\hline Tabaqa & Euphrates & 60 & $\mathrm{P}, \mathrm{I}$ & 1975 \\
\hline Tishrine & Euphrates & 40 & $\mathrm{P}$ & 1999 \\
\hline Upper Khabour & Khabour & & I & 1992 \\
\hline \multicolumn{5}{|c|}{ F: Flood Control I: Irrigation M: Military P: Powe } \\
\hline
\end{tabular}

The confluence of the Tigris and Euphrates Rivers at Qurna city forms Shat AlArab River. The catchment of this river shared between Iraq and Iran. The main tributary to this river is Karun, which rises in Iran. Iran tries to secure its interest in Karun and Shatt Al- Arab. Recently, Iran diverted all the waters of the tributaries, including Karun inside its borders (Abdullah, 2012).

In addition to the above, water scarcity in Iraq can be attributed to:

a. International and Regional problems.

b. Internal problems.

\section{International and Regional Problems.}

\subsection{Climate Change}

\section{Background}

Iraq is one of the countries, which are highly vulnerable to climate change and to its variability (IPCC 2014). Iraq is one part of a very large zone of generally varied climatic conditions categorized by a high degree of aridity, highly variability and very low annual rainfall (Medany, 2008) and that, which can experience major environmental changes due to any climatic shift. Most of parts of Iraq are classified as having arid to semiarid climate, ranging from semi-humid in the north to semiarid in the south due to the typical annual precipitation being below $150 \mathrm{~mm}$ (AlAnsari et al., 2017). This makes Iraq significantly vulnerable to any slight change in climate. Water scarcity has recently emerged as an issue in large parts in Iraq, particularly in the south, and could get worse due to changing climate (IPCC, 2014). Arguably, climate change is one of the greatest challenges confronting this region: it can have significantly adverse effects on water resources and hence the environment and economy, particularly in the agricultural sector. Thus, there is an imperative need for predicting the potential impacts of climate change, specifically 
on the duration and magnitude of precipitation, that have ramifications for sustaining and managing water resources appropriately. It has been reported already for some regions that water scarcity has become significantly worse (Chowdhury et al., 2014; Al-Ansari et al., 2014). Unfortunately, up to-date, water issues related to climate change have not been well addressed within climate change analyses and climate policy construction (IPCC, 2014) and, particularly, in Iraq, where very little attention has been paid to climate change-related water resources issues (Issa et al., 2014). Given this perspective, the main objective of this section is to highlight the observed changes in climate trend and streamflow as well as the adverse impacts of these changes that have already impinged on the water sector and keeps to do so and hence hitting the agriculture sector in Iraq.

\section{Observed climate and trends in Iraq}

The primary controlling factors of a climatic regime are atmospheric temperature and precipitation. If these two factors change, other factors such as humidity will be affected. It is therefore imperative to study thoroughly changes in atmospheric temperature and precipitation to investigate possible climate change. This section describes the observed and projected changes in climate as they relate to water in this region.

\subsection{Air temperature}

Climate shift in all regions of the world has been significant since the last century, mainly through observed increases in surface air temperature (IPCC, 2014). Since the $1950 \mathrm{~s}$ the average temperature has increased by $0.2^{\circ} \mathrm{C}$ to $0.3^{\circ} \mathrm{C}$ per decade (Zakaria et al., 2013). Recent studies have shown that the air temperatures in the last three decades (1980-2017) in Iraq has risen by $0.7^{\circ} \mathrm{C}$ per decade (Abbas et al., 2017). The IPCC (2014) points out that Iraqi surface air temperature had increased unevenly from 1970 to 2003 , ranging from $0.2^{\circ} \mathrm{C}$ to $2^{\circ} \mathrm{C}$, and it is expected to increase by about $5^{\circ} \mathrm{C}$ by the end of the 21 st century (Abbas et al., 2019). These changes will give rise to a higher level of climate variability; potentially resulting in a higher frequency of extreme weather events.

\subsection{Rainfall}

Zakaria et al. (2013) show that an increase and decrease of average annual rainfall occurred over the historical periods 1900-1930, 1930-1960, 1960-1990 and 19902009. The average annual rainfall for the four historical sub-periods was 182.5 , $194.7,168.9$ and $162.6 \mathrm{~mm}$, respectively. Comparing the first and the second subperiods, the total rainfall value showed a percentage increase of $6.68 \%$. However, from the second to the third sub-periods the total rainfall showed a percentage decrease of $13.25 \%$. From the third to the fourth sub-periods the total rainfall decreased again by $6.3 \mathrm{~mm}$ with $3.73 \%$ reduction. The average annual rainfall was decreasing from $194.7 \mathrm{~mm}$ during the period of 1930 -1960 to reach its lowest value of 162.6 mm during 1990-2009 (Figure 2). These results are in line with the findings 
of Abbas et al. (2017) who state that rainfall has declined from about $177 \mathrm{~mm}$ in 1980 to 156 in 2017. Abbas et al. (2017) also point out that the decline trend is expected to continue over the next decades.

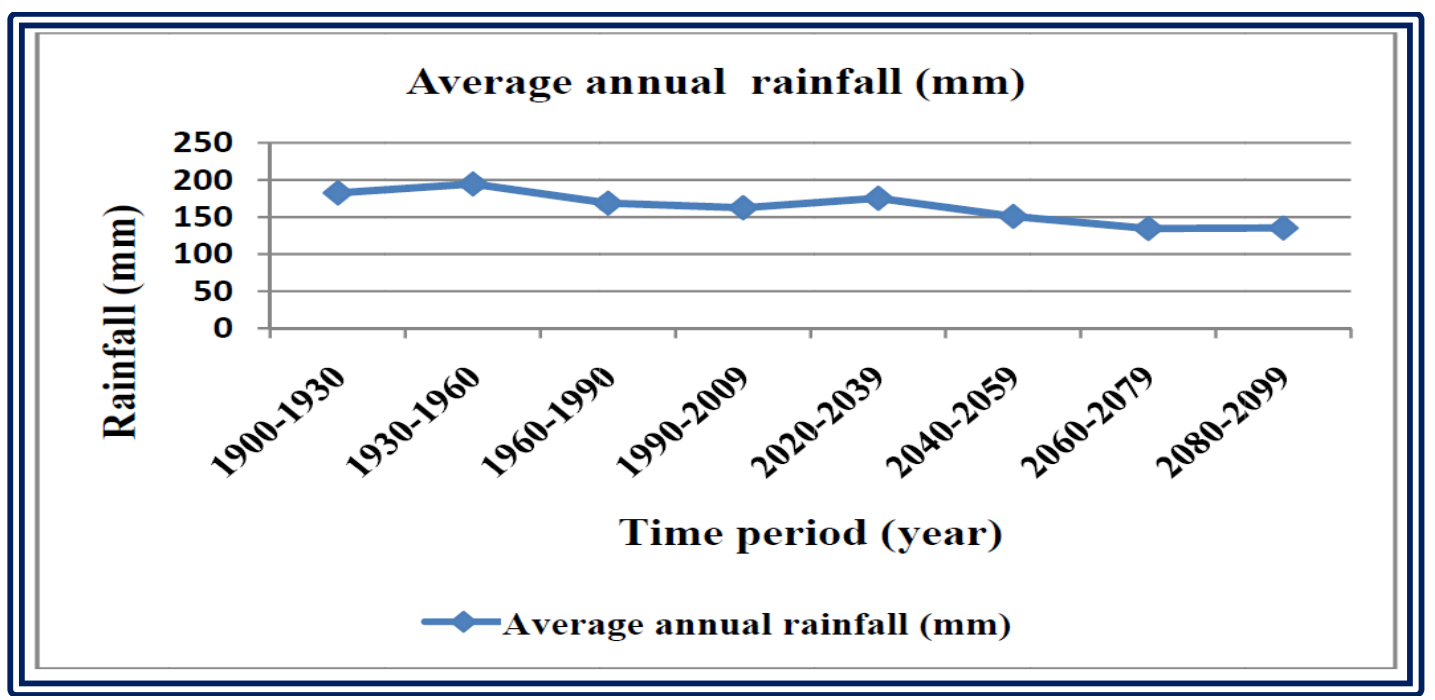

Figure 2: Average annual rainfall ( $\mathrm{mm}$ ) over the historical and future periods (Zakaria et al., 2013).

\subsection{Weather pattern changes}

Several profound issues that can be attributed to climate change have been apparent in the Iraqi climate. The desertification processes, frequent and intense dust storms, rising air temperatures above $50^{\circ} \mathrm{C}$, prolonged drought conditions and sudden, heavy rainfall and storms have become increasingly frequent in the Iraqi climate (Janabi, 2013). For example, the extreme drought that occurred between 2005 and 2007 was followed by several months of sudden heavy rainfall and storms during which vast parts of central and southern Iraq received $200 \%$ of normal rainfall (UN, 2013). The effects of significant changes in weather patterns are exacerbated by inability to store water during rainfall events, abandonment of agricultural land during drought, reduction in flow rates in the Tigris and Euphrates Rivers, shrinking of the marshlands, soil erosion and an increased salinity in the Shatt al-Arab estuary as well as in groundwater in the south.

\section{Climate change and its impacts on water resources}

Besides the challenges mentioned above that are facing Iraqi's rivers waterflow, climate change and significant increases in population growth are exacerbating water scarcity. Climate change warns to decrease water availability and deteriorate water quality (Al-Ansari et al., 2014; Abbas et al., 2020). Iraq is one of the region's countries that is considered most vulnerable to climate change (IPCC, 2014). The impacts of climate change have been obvious, as air temperatures increase is 
resulting in increasing evaporation, declining precipitation, and changing weather patterns that are contributing to water scarcity. According to observed studies, scarcity of fresh water and the rise in sea level in Iraq has been felt and noticed in last few decades. Iraq's rivers discharges have decreased to less than a third of their normal flow and are expected to decrease further by an alarming $50 \%$ by 2030 , compared to 1980s due to water-related activities of upper riparian countries and climate change (Al-Ansari et al., 2014; Chenoweth et al., 2011). Abbas et al. (2020) evaluated water resources per capita per year during the period of 1980-2014 in the northeast Iraq. They found that the water use per capita has decreased in the southern part and has experienced less than $500 \mathrm{~m}^{3}$ per capita per year (Figure 3) with high spatial distribution due to the geographic factor, water availability decreases from upstream mountainous areas to downstream flat areas since annual precipitation decreases from north to south. The social factor is that northern areas are sparsely populated, whereas southern areas are densely populated with some large metropolitan areas, resulting in decreased water quality. In general, a major part of the region is experiencing severe water scarcity which corresponds to areas with high population density adding more complexity to the problem.

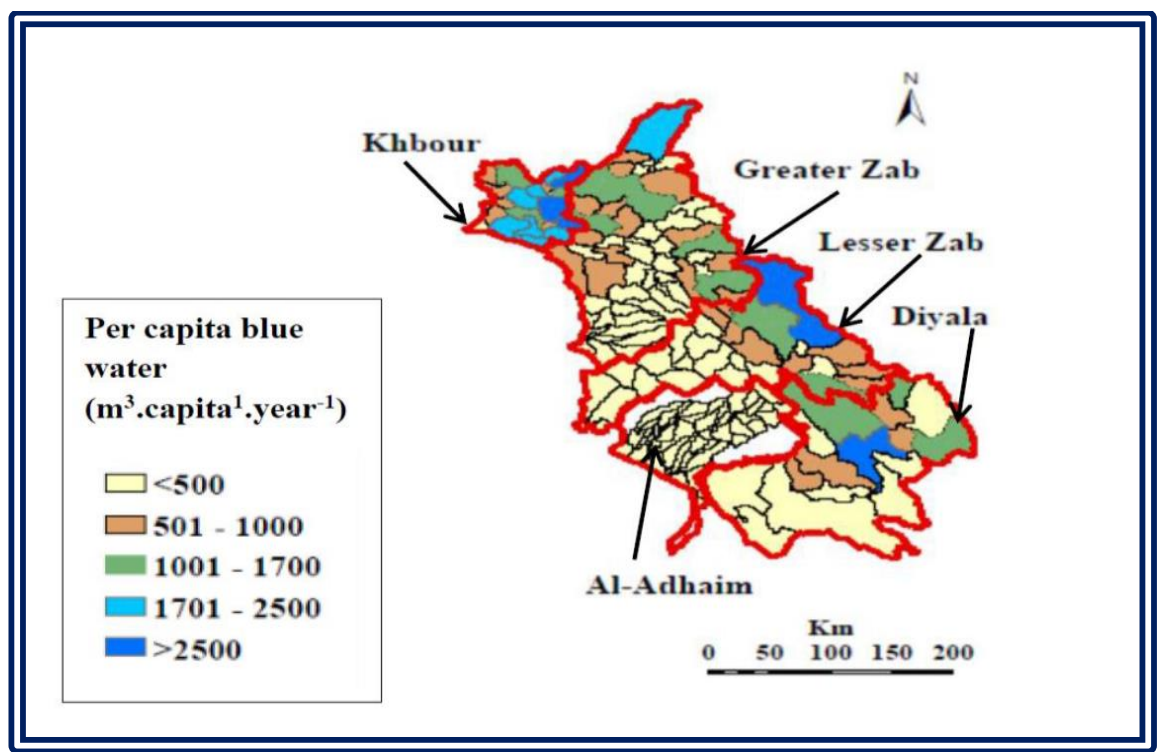

Figure 3: Water availability in northeast Iraq in 2005; average annual blue water flow availability per capita per year using population of 2005 (According to Abbas et al., 2020).

Abbas et al. (2020), investigated further soil water content in northeast Iraq, which although is often ignored in water resources management, it plays a fundamental role in rain-fed crop production and for other environmental purposes (Zang et al., 2012). Abbas et al. (2020) assessed the soil water availability by the average number 
of months per year for the period 1980-2014 when soil water content is available (defined as $>1$ mm.m-1) as shown in Figure 4. Soil water content availability analysis showed that, apart from the Khbour Basin, which has experienced nine to ten months when soil water content was accessible, the four tributaries catchments have experienced five to six months per year of groundwater availability. Therefore, large areas of the region can often experience reduced crop yield due to lack of soil water availability, particularly downstream catchments such as the Al-Adhiam Basin. These areas require irrigation systems, which can adjust to high demands or adoption of alternative cropping practices that require less water.

To gain an appreciation of what is going on at local levels, where transportation of water mostly seems infeasible due to lack of infrastructure, Abbas et al. (2020) looked at four townships: Duhok, Al-Sulaymaniyah, Erbil and Al-Ta'mim (Kirkuk governorate). These range from high- to low-precipitation townships. The results of the analysis are presented in Figure 5. The locations of the townships are shown in Figure 6. The soil water content at Al-Ta'mim is not as poor as it may appear from the precipitation values only.

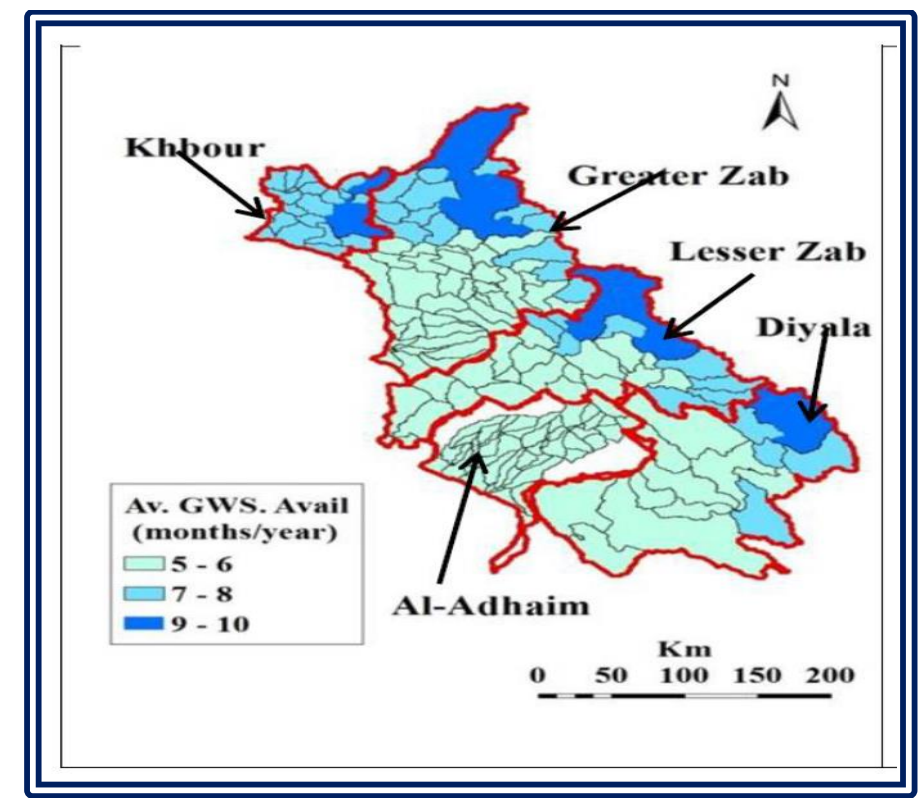

Figure 4: The 1980-2010 average soil water content (Ground Soil Water, GWS). 


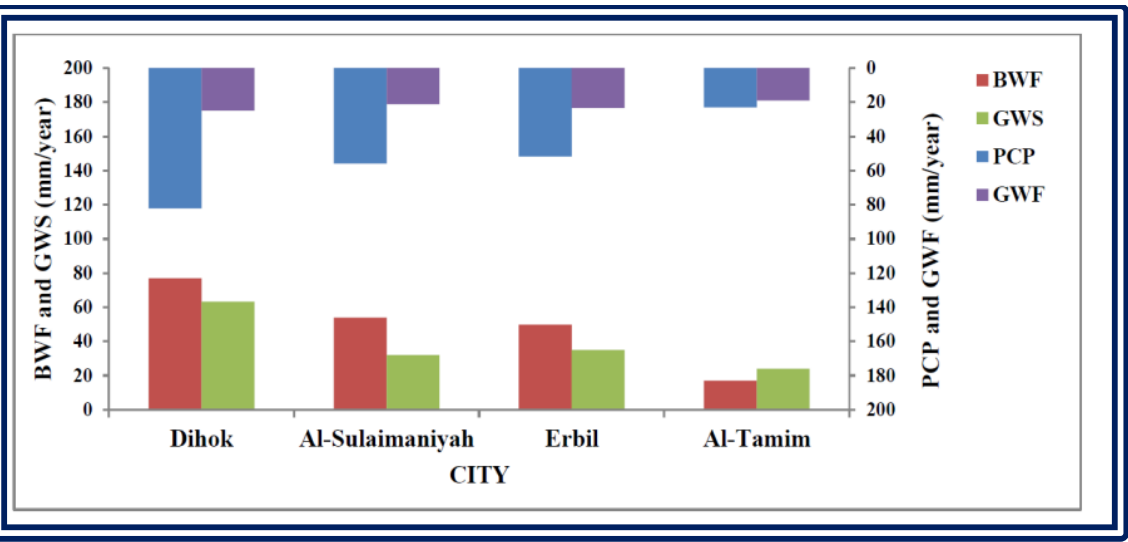

Figure 5: Simulated average (1980-2010) annual city precipitation (PCP), surface water flow (BWF), ground water flow (GWF) and soil water content (GWS) for four major cities in northeast Iraq.

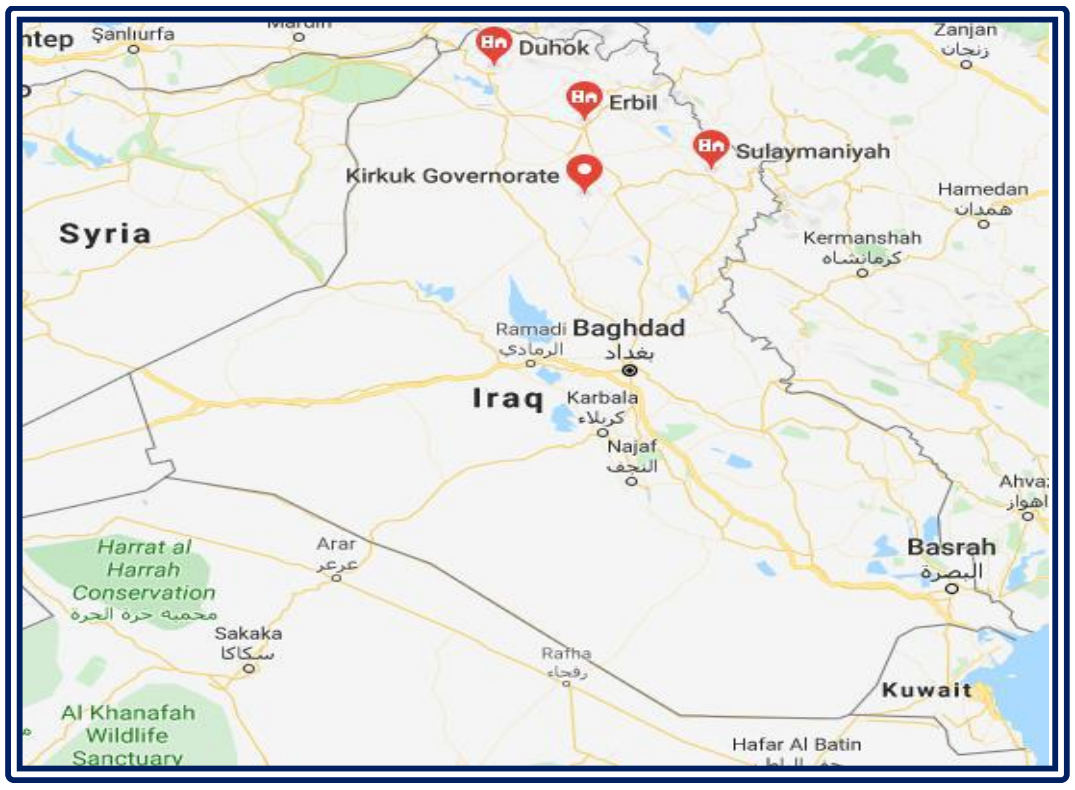

Figure 6: The map showing the location of townships where water resources availability was looked at township level (Iraqi Ministry of Water Resources, 2015). 
Abbas et al, (2020) modelled the impacts of climate change on northeast Iraq for distant future (2080-2100). They found that the basin will experience increasing temperatures and decreasing annual precipitation that will have far-reaching consequences, with the highest impact in the southern part and likelihood of rising temperatures up to $50^{\circ} \mathrm{C}$. The results from the hydrological modelling for annual stream flow show that in five tributaries streamflow will significantly decrease for all scenarios. These findings may have significant effects, because a large area already suffers from per capita water scarcity.

Besides the negative climate change impacts, water resources have been pressured by continued contamination, salinization of the two rivers, due to the excessive use of fertilizers, and discharge of industry effluence and domestic waste and sewerage without sufficient treatment (Al-Ansari et al., 2014).

\section{Impacts of climate change on Sea Level Rise (SLR)}

Globally, mean sea level has increased by $200 \mathrm{~mm}$ since the late 19th century at a rate of $2.8 \mathrm{~mm} /$ year (Figure 7). Rising sea levels have accelerated to $3.2 \mathrm{~mm} /$ year over the last three decades (Lough and Hobday, 2011) at a rate near to the upper end of the Intergovernmental Panel on Climate Change projections (Keenan and Cleugh, 2011). This is mostly due to thermal expansion of the oceans, with a small contribution from the loss of mass from land ice (Church et al., 2006; Gregory and Huybrechts, 2006).

Al-Ansari (2016) reported that the Arabian Gulf is projected to be highly vulnerable at its northern part, north of Kuwait and south of Iraq (Shat Al-Arab), to SLR. Despite the limited shoreline of Iraq on the Arabian Gulf, SLR would impact the major cities in Iraq such as Basra and Baghdad due to low elevation of the lands (Al-Ansari, 2016; Figure 8). SLR would potentially have impacts on increasing soil salinity due to saltwater intrusion and may cause serious inundation of many parts of the region. The other possible impact is land inundation, due to the very low elevation of the land, make it highly susceptible to any amount of sea level rise (El Raey, 2011). 


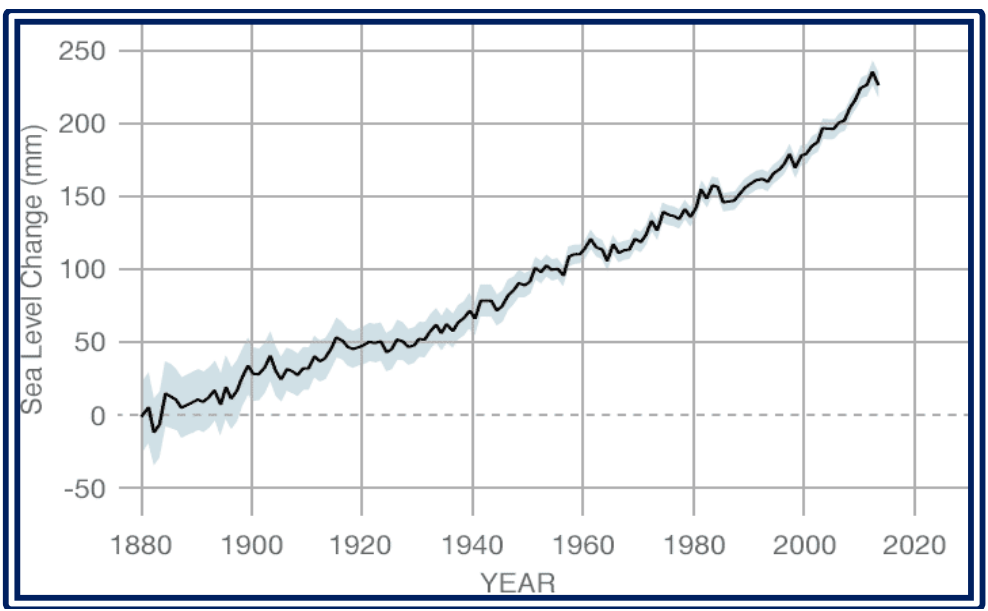

Figure 7: Global Mean Sea Level (GMSL), 1880-2020 (Church and White, 2006).

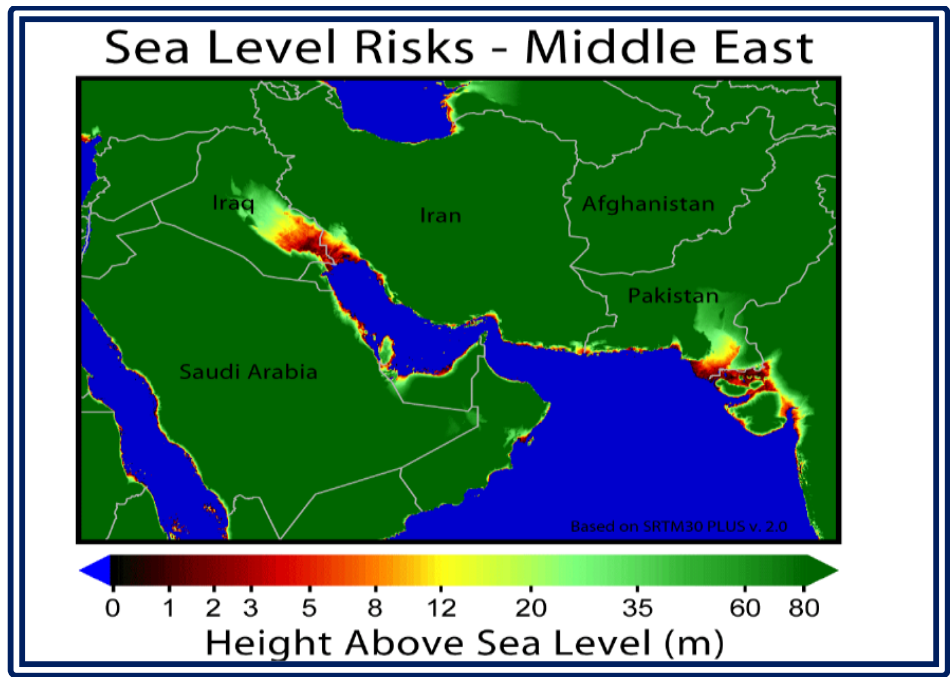

Figure 8: Effect of sea level rise in Iraq and Kuwait (Al-Ansari, 2016).

\section{Impacts of climate change on Agriculture}

Agriculture is the second largest contributor to the country's gross domestic product, and it is the main source of livelihood for $25 \%$ of the population (USAID, 2017). Agriculture is mainly categorized by small-scale farms that are almost rain-fed in the north and irrigated in other regions. Climate change impacts on agriculture have been evidenced in recent decades (Al-Ansari, 2013). The ongoing decline of the agricultural sector, driven partially by climate change, has been increasingly noted in the sustained loss of arable land, productivity losses, and decline in agriculture's overall contribution to GDP (Ministry of Foreign Affairs, 2017). USAID (2017) has identified three stressors related to climate change which are: increased 
temperatures, Greater Frequency and Intensity of Drought and Increased Intensity of rainfall events.

\section{Increased temperatures stress}

Increased temperatures have led to reductions in the agricultural productivity in the large part of Iraq (USIAD, 2017). Temperature is a key factor contributing to the rate of plant development. Warmer temperatures associated with climate change have declined plant productivity worldwide (Al-Ansari, 2013). Plants exposure to temperature extremes at the commencement of the reproductive stage have a major impact on fruit or grain production across all species (Hatfield and Prueger, 2015).

\section{Greater Frequency and Intensity of drought}

Climate change has impacted a large agricultural part in Iraq by increasing desertification, deteriorating agricultural development, and diminishing livestock, which resulted from degradation and lack of natural vegetation. This in turn has negatively affected the human and food security of the country. Continued decreased rainfall and runoff have been a significant contributor to widespread desertification and sand and dust storms resulting in arable land loss (USAID, 2017). It is estimated that desertification threatens $92 \%$ of the country. During the drought between 2007-2009, mostly $40 \%$ of cropland throughout Iraq experienced reduced crop coverage and livestock were perished. The situation caused 20,000 rural inhabitants to move in search of more sustainable access to drinking water and livelihoods (USAID, 2017). The events of dust storms (sandstorms) have enormously increased, as compared with those occurring during the last century due to climate change (Sissakian et al., 2013). Dust storms have undermined Iraq's agricultural sector. Sand and dust storms endanger cropland and productivity due to soil loss, reducing soil fertility, and removing organic matter (Al-Ansari, 2013). Currently, dust storms sometimes occur at a rate of over 100 times/year but could occur up to 300 times annually in ten years. Further reductions in arable land and productivity could also result in loss of livelihoods and increased food insecurity (Janabi, 2013). Figure 9 shows the widespread of sand and dust storm in Iraq.

\section{Increased intensity of rainfall events}

In Iraq, climate change has been responsible for unpredictable precipitation, higher than average and increased disaster risk intensity. In 2013 (USAID, 2017; Janabi, 2013) severe flooding damaged approximately 75,000 acres of cropland in southeastern and eastern Iraq. In 2019, Iraq experienced an oddly wet winter leading to restoring freshwater marshes of southern Iraq, however caused widespread flooding on the Tigris and Euphrates rivers.

Without immediate adaptation measures taken, the agricultural production will suffer more significantly. Rain-fed agricultural lands and production will likely decrease significantly because of shorter growing seasons and less precipitation (AlAnsari et al., 2014). 
To avoid future generations having to pay a premium price to deal with the adverse effects of climate change, it is imperative that these aspects are taken into consideration in formulating climate change policies for the region. Relevant policies to deal with climate change in the field of water resources may include, for instance, recycling of waste water, steps and measures to mitigate and adapt to these impacts through (for example) water-reuse measures, water-sensitive urban infrastructure design such as rainwater tanks, rain gardens and constructed wetland, and growing plants tolerant to drought.

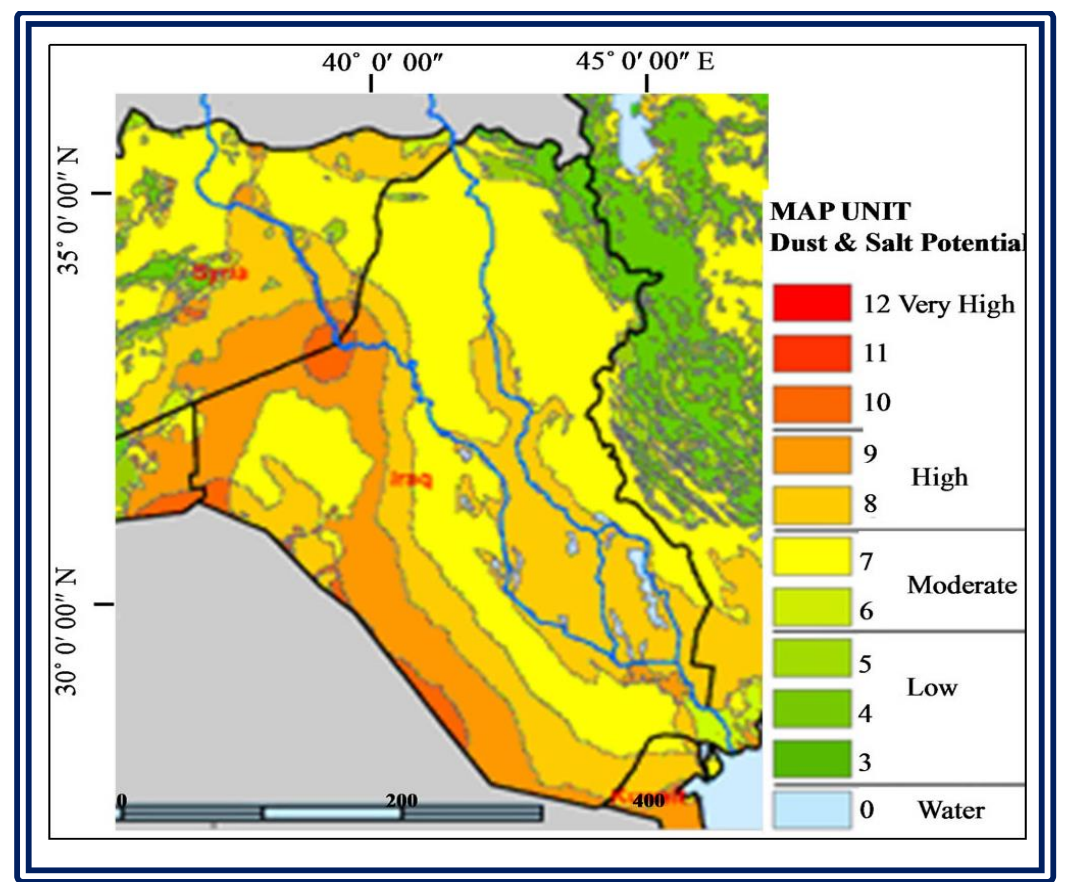

Figure 9: Spatially distribution of dust and sandstorm event throughout Iraq (Al-Ansari, 2013).

\section{Conclusion}

Although it is not easy to draw concrete conclusions on climate change impacts on water resources in Iraq, due to extreme shortage of modelled studies in this area, it can be seen clearly from few observed and modelled studies that the region is subjected to extreme negative climate change impacts on water and land resources. These will inevitably have absolute severe circumstances for Iraqi community such as poverty, unemployment, lack of agricultural products. Enormous volume of studies and research should be done for the whole region to fill the gap of lack of knowledge of climate change impacts- related water issues. This would support decision makers in planning relevant adaptation and mitigation policies, and thus decreasing the expected adverse impacts on water resources in the basin. 


\subsection{Hydrological Projects within Riparian Countries}

All landowners whose property adjoins a body of water or river have the right to make reasonable use of it and the right to access for swimming, boating and fishing as it flows through or over their property. If water is lacking to satisfy all landowners, rations are generally fixed in proportion to frontage on the water source (Guerin, 2003).

Many studies tried to draw figures for the water requirement for Turkey, Syria and Iraq (the riparian countries) from Euphrates and Tigris Rivers. Estimates for required water from Euphrates River to irrigate all the cultivated lands along it are $15.7,11$ and $13 \mathrm{~km}^{3}$ for Turkey, Syria and Iraq, respectively. It should be mentioned however that, other authors had cited different figures for the water requirement for Turkey, Syria $\left(7.95 \mathrm{~km}^{3}\right)$ and Iraq $\left(19 \mathrm{~km}^{3}\right)$ (Kamona, 2003).

During the 1970s Syria and Turkey started to construct dams on the Euphrates and Tigris Rivers which caused a major decrease in the flow of the rivers (Al-Ansari, 1998; Al-Ansari and Knutsson, 2011) as well as deterioration of the quality of their water (Kamel et.al., 2013).

In 1977, the Turkish government set a huge project referred to as Southeastern Anatolia Project (GAP, 2006). The component of the project includes 22 dams and 19 hydraulic power plants which are supposed to irrigate $17,000 \mathrm{~km}^{2}$ of land (Unver, 1997). The project is supposed to develop the southeastern provinces which cover $9.7 \%$ of the total area of Turkey which forms $20 \%$ of the agricultural land of the country. The overall volume of water to be captured is about $100 \mathrm{~km}^{3}$ (while the required water to irrigate the supposed area is about $29 \mathrm{~km}^{3}$ ) which is three times more than the overall capacity of Iraq and Syrian reservoirs. Despite the continuous claims of the Turkish Government that GAP is purely development project, it seems that there are number of internal and external goals involved (Shams, 2006; Alnajaf News Net, 2009; Waterbury, 1993; Alsowdani, 2005; National Defense Magazine, 2009). When GAP project is completed, then $80 \%$ of the Euphrates water will be controlled by Turkey (Beaumont, 1995; Alyaseri, 2009; Robertson, 2009).

When Ilisu dam on Tigris River is operating then, Iraq will receive only $9.7 \mathrm{~km}^{3}$ (Ritzema and Braun, 1994). This implies that $47 \%$ of the river flow will be depleted. This in turn means that 696,000 ha of agricultural land will be abandoned due to water scarcity (Al-Ansari and Knutsson, 2011). Recent reports state that Tigris and Euphrates rivers will be completely dry by 2040 (UN, 2010).

Syria built three main dams along Euphrates River with a total storage capacity of $16.1 \mathrm{~km}^{3}$ for irrigation and electricity generation.

Syria used to receive $21 \mathrm{~km}^{3} /$ year of the Euphrates water prior 1990 which dropped to $12 \mathrm{~km}^{3}$ in 2000 onward (40\% reduction). As far as Iraq is concerned, the volume of water received dropped from $29 \mathrm{~km}^{3}$ before 1990 (Majeed, 1993) to $4.4 \mathrm{~km}^{3}$ ( $85 \%$ reduction) now. Due to this reduction in water shares, the agricultural used land in both countries had been reduced from 650,000 ha to 240,000 ha. In addition, the quality of water deteriorated due to back water irrigation directed toward the main channel in its upstream reaches (Al-Ansari and Knutsson, 2011). 
Syria is planning to double its irrigated area $(740,000 \mathrm{ha})$. This will increase its water withdrawal from $5 \mathrm{~km}^{3}$ to $9 \mathrm{~km}^{3}$ (World Bank, 2006).

In addition to the above, Iran had recently diverted all perennial valleys running toward Iraq inside Iran. Furthermore, water of Karkha and Karun Rivers had been almost completely diverted inside the Iranian borders and no water is contributing to Shatt Al-Arab River from these tributaries (Figure 10).

Shatt Al-Arab River is formed after the confluence of Tigris and Euphrates Rivers at Qumah in Iraq. Karun and Karkha Rivers usually contributes 24.5 and 5.8 billion cubic meters (BCM) annually respectively. This forms about $41 \%$ of the water of Shatt Al-Arab. The decrease of the water discharge of the Tigris and Euphrates Rivers and the diversion of the water of Karun and Karkha tributaries caused the salinity to increase to $2408 \mathrm{mg} / \mathrm{I}$ in 2011 (UN-ESCWA and BGR, 2013).

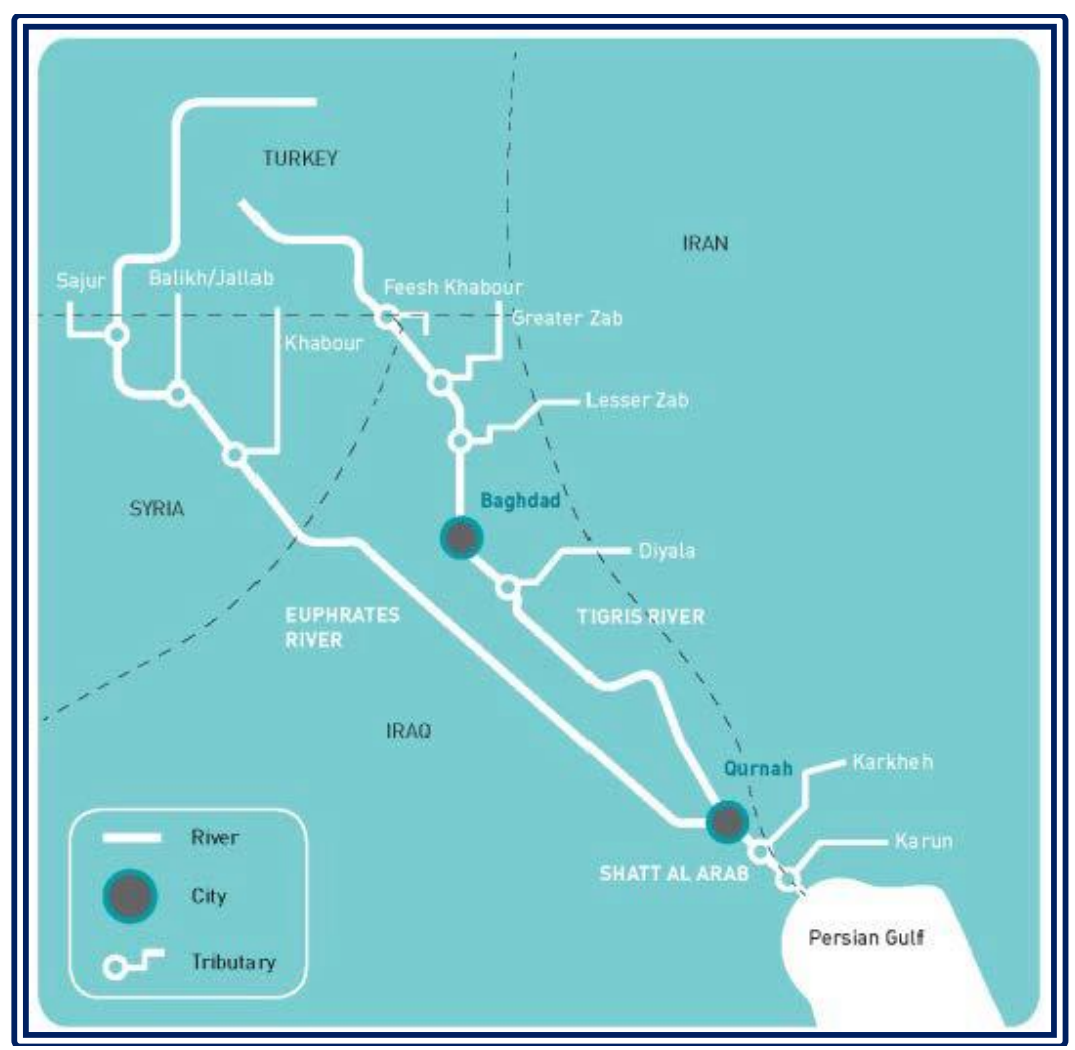

Figure 10: Schematic diagram of Tigris, Euphrates and Shatt Al-Arab Rivers system (UN-ESCWA and BGR, 2013). 


\section{Causes of the Friction, Tension and Conflict}

\section{a. Water Availability}

Different figures are published for the water allocation per capita per year (Tables 2 and 3). The figures given do not include restoring of the marshes in Iraq, and it ignore the situation when GAP project is fully operating. Irrespective of the numbers given, Turkey claims that the allocations of water per capita in Iraq and Syria are sufficient to fulfill the requested quantities that achieve the people needs in these countries (Altinbilek, 2004).

Table 2: Water allocation per capita per year in Turkey, Syria and Iraq (source of data a- Bilen, 2000; b- Turkish Ministry of Foreign Affairs, 2012).

\begin{tabular}{|c|c|c|c|c|}
\hline \multirow{2}{*}{ Country } & \multicolumn{4}{|c|}{ Water Allocation (m $/$ Capita/year) } \\
\cline { 2 - 5 } & $\mathbf{1 9 9 0}$ & $\mathbf{2 0 0 0}$ & $\mathbf{2 0 1 0}$ & $\mathbf{2 0 2 0}$ \\
\hline Turkey & 3223 & 2703 & 2326 & $2002^{\mathbf{a}}, 980^{\mathbf{b}}$ \\
\hline Syria & 1636 & 117 & 880 & $760^{\mathbf{a}}, 780^{\mathbf{b}}$ \\
\hline Iraq & 2352 & 1848 & 1435 & $1062^{\mathbf{a}}, 950^{\mathbf{b}}$ \\
\hline
\end{tabular}

The flow of the two main rivers is decreasing with time (Figures 2, 3 and 4). This is mainly due to the Turkish policy of build the dams in the upper parts for the catchment areas of the Tigris and Euphrates and climate change (Al-Ansari et.al., 2014a, b; Osman et.al., 2017a, b, c; Al-Ansari, 2013, 2016; IPCC, 2007). Surface and groundwater resources will be decreased with time (Voss et.al, 2013; Chenoweth et.al, 2011; Bazzaz, 1993). Future predictions suggest lower precipitation accompanied with higher temperatures (Al-Ansari et.al., 2014d). Serious consequences are expected where (as an example, $71 \%$ of the Euphrates River is come from precipitation in Turkey), (UNDP, 2011). This condition will lead to more evaporation and drought periods (UNEP, 2011; Hameed et al., 2018). UN (2010) report indicated that these conditions will eventually lead to the dryness of the Tigris and Euphrates Rivers by 2040. In addition, all riparian countries within the catchments of the two rivers will be most water stressed by 2040 (Maddocks et al., 2015).

\section{b. Population growth rate and food security}

Population growth rates are relatively high in the ME particularly Syria and Iraq (Drake, 2007). Historically, the area (Arab countries only) was populated with about 20 million inhabitants in 1750, and the number in 1996 is 286 million (Drake, 2007). As far as the four main countries that lie within the Tigris and Euphrates basins (Turkey, Iran, Syria and Iraq) their total population is 221.53 million inhabitants (Worldmeter, 2018a, b, c, d). This number will increase by about $10 \%$ in 2025 and about $37 \%$ in 2050 (Table 2). Accordingly, the allocation of water per capita will decrease too (Abumoghli, 2015). The allocation within the Tigris and Euphrates basins is about $975.3 \mathrm{~m}^{3} / \mathrm{yr} / \mathrm{capita}$ now (Table 3) and this will drop to 887.6 and $709.2 \mathrm{~m}^{3} / \mathrm{yr} / \mathrm{capita}$ in 2025 and 2050 respectively. It is noteworthy to mention that there are other references that give different figures, but the outcome is the same 
where there will be decrease in water allocations with time.

Table 3: Population Characteristics within Tigris-Euphrates Basins (modified from Worldmeter, 2018a, b, c, d and Drake, 2007).

\begin{tabular}{|c|c|c|c|c|c|}
\hline \multirow[t]{2}{*}{ Country } & \multirow[t]{2}{*}{$\begin{array}{l}\text { Population } \\
\text { (million) }\end{array}$} & \multirow{2}{*}{$\begin{array}{c}\text { Rate of } \\
\text { Growth } \\
(\%)\end{array}$} & \multicolumn{2}{|c|}{$\begin{array}{c}\text { Projected population } \\
\text { (million) }\end{array}$} & \multirow[t]{2}{*}{$\begin{array}{c}\text { Percent } \\
\text { Urban }\end{array}$} \\
\hline & & & 2025 & 2050 & \\
\hline Turkey & 81.91 & 1.45 & 86,12 & $\begin{array}{c}95.62 \\
95.819 * *\end{array}$ & 71 \\
\hline Syria & 18.28 & 3.7 & 23.41 & $\begin{array}{c}34.02 \\
34.90^{* *}\end{array}$ & 75 \\
\hline Iraq & 39.33 & 2.78 & 47.19 & $\begin{array}{c}81.49 \\
83.65^{* *}\end{array}$ & 66.9 \\
\hline Iran & 82.01 & 1.05 & 86.72 & $\begin{array}{c}93.55 \\
92.21 * *\end{array}$ & 73.8 \\
\hline Total & 221.53 & & 243.44 & 304.68 & \\
\hline \multicolumn{6}{|c|}{$\begin{array}{l}\text { **Wikipedia, The anticipated population growth for several middle eastern } \\
\text { countries (United Nations, medium fertility variant) } \\
\text { https://en.wikipedia.org/wiki/List_of_countries_by_future_population_(United_ } \\
\text { Nations,_medium_fertility_variant) }\end{array}$} \\
\hline
\end{tabular}

Governments in the ME try to attain food self-sufficiency and for this reason, the agriculture is considered as the largest consumer for water, it is consume $66 \%$ of the total demand (Hiniker, 1999; Allan, 2001). Countries within the Tigris and Euphrates basin allocate as an average $84.3 \%$ of the water consumption for agricultural purposes (Table 4). Iran has the maximum water allocation (92\%) While Turkey (73\%) has relatively the minimum water allocation for agriculture (FAO, 2008a, b, c, d). Thorough consideration of agriculture is required to objectively analyze and adequately address the water shortage problem (Sadik and Barghouti,1995). However, this is not the case where countries have extremely ambitious goals to secure the self-sufficiency of food, and they require a core changes in water management policies and widens their national outlook (Charrier and Curtin, 2007). Recently, achieving the increasing demands for water represent a severe challenge because it is over the abilities of each individual country (Sadik and Barghouti, 1995). Turkey is trying to convert the area of the GAP into a breadbasket, and this threatens the irrigation based agricultural potential of the lower riparian Syria and Iraq (Hillel, 1994). Iraq and Syria were exporting the grains for different countries, but now they are importing their needs for grains, and their agricultural production decreased to become less than Turkey (Hillel, 1994). Syria tried long time ago to achieve food self-sufficiency and to increase its irrigational areas; drip irrigation was used. As a result, severe reduction in wheat yield has been occurred; it was a decrease up to $50 \%$. In addition, huge portion of livestock died due to water scarcity. Consequently, many individuals joined to the insurgents to 
save themselves and their families (New York Times, 2013). Iraq tried to increase its agricultural lands and become a grain exporter again by 2017 (United Nations and World Bank, 2003; Al Ansary, 2015). Numerous projects were executed but salinity and water logging created serious problems for agricultural activities. After the second Gulf war, Iraq is importing its food reflecting disastrous agricultural conditions (Robertson, 2009; Cockburn, 2009). Recently, food security and selfsufficiency are not a major concern in both Iraq and Syria where national security problems, especially the threat of ISIS is the priority now.

Table 4: Water use in countries within Tigris and Euphrates basins (according FAO 2008a, b, c, d and 2009 a, b, c).

\begin{tabular}{|c|c|c|c|c|c|c|}
\hline \multirow[t]{2}{*}{ Country } & \multirow{2}{*}{$\begin{array}{c}\text { Water } \\
\text { Allocation } \\
\text { Per inhabitant } \\
\left(\mathrm{m}^{3} / \mathrm{y}\right)\end{array}$} & \multirow{2}{*}{$\begin{array}{c}\text { Cultivated } \\
\text { area } \\
\text { (ha) }\end{array}$} & \multicolumn{4}{|c|}{$\begin{array}{c}\text { Water withdrawal } \\
\left(10^{6} \mathrm{~m}^{3} / \mathrm{y}\right)\end{array}$} \\
\hline & & & Total & $\begin{array}{l}\text { Irrigation } \\
\text { +livestock }\end{array}$ & Municipalities & Industry \\
\hline Turkey & 563 & $26,606,000$ & 40,100 & $\begin{array}{c}29,600 \\
73 \%\end{array}$ & 6,200 & 4,300 \\
\hline Syria & 921 & $5,742,000$ & 16,690 & $\begin{array}{c}14,669 \\
87 \%\end{array}$ & 1,426 & 595 \\
\hline Iran & 1356 & $18,107,000$ & 93,300 & $\begin{array}{c}86,000 \\
92 \%\end{array}$ & 6,200 & 1,100 \\
\hline Iraq & 2632 & $6,010,000$ & 66,000 & $\begin{array}{l}52,000 \\
79 \%\end{array}$ & 4,300 & 9,700 \\
\hline Total & & & 216,090 & $\begin{array}{l}182,269 \\
84.3 \%\end{array}$ & $\begin{array}{c}18,126 \\
8.4 \%\end{array}$ & $\begin{array}{c}15,695 \\
7.3 \% \\
\end{array}$ \\
\hline
\end{tabular}

\section{c. Energy Requirements}

Iraq is an oil exporting country since the beginning of the twentieth century, while Syria started to export oil in 2001 and, Turkey has no oil reserves (Akanda et.al., 2007). For this reason, Turkey is trying to reduce its dependence on oil imports as an energy source. To achieve this goal, Turkey is trying to use hydroelectric power to cover as much as $40 \%$ of the required energy (Turan, 2004). The GAP project is one of the strategies used so that Turkey can reduce 28 million tons of its oil imports when this project is fully operational (Bagis, 1989).

Syria and partially Iraq relies on hydropower to generate electricity. Despite the fact that Syria is oil producer, but it relies on hydropower to generate electricity. This fact gives the opportunity for Turkey to decrease the water quantities which release from the Euphrates through the GAP project and put Syria under threat. Although, the Turkish Government declared several times that the GAP is purely a development project. Some people believe there are several external and internal strategies involved within the implementation of the GAP project (Waterbury, 1993; Alsowdani, 2005; Shams, 2006; Alnajaf News Net, 2009; National Defense Magazine, 2009). 


\section{d. Water Management}

Poor water management strategies have exacerbated the water scarcity problems within riparian countries (Abumoghli, 2015). Water is wasted through old irrigation techniques where flood irrigation is still the dominant method used. In addition, the irrigation canals are unlined and/or uncovered, which enhance water losses. Water qualities of the rivers are deteriorating due to the extensive use of chemical fertilizers and pesticide. Back flow from irrigated areas and dispose of the industrial and municipal wastes into the rivers is accelerating the contamination of these rivers. Recent data for the period 2000 to 2010 collected by the Consulting Engineering Bureau at Baghdad University (CEB, 2011a) show the steady increase of the salinity in both rivers (Figure 11). Similar trend was noticed by ESCWA (2013) for long term salinity trend in both rivers. TDS is about $300 \mathrm{ppm}$ at Ataturk Dam on the Euphrates, and it increases to $600 \mathrm{ppm}$ at the Syrian-Iraqi borders which are much more than the recommended TSD concentration for irrigation, and it is continued to increase for more than $1200 \mathrm{ppm}$ (minimum) downstream in the Iraqi southern. Specifically, at Samawah (World Bank, 2006; Iraqi Ministry of Municipalities and Public Work-IMMPW, 2011). As far as the salinity within the Tigris River, it increases dramatically downstream Baghdad due to intensive irrigation. To overcome the salinity problem in Iraq, a main outfall drain (MOD) was constructed south of Baghdad to the Gulf for a distance of $565 \mathrm{~km}$ to carry drainage water from irrigation projects from $150,000 \mathrm{~km}^{2}$ with a discharge capacity of $210 \mathrm{~m}^{3} / \mathrm{s}$ (UNEP, 2003; Shahin, 2007). To overcome salinization and water logging, huge networks and sub-surface tile drains, and surface drainage canals were constructed to collect drainage water from agricultural fields to be dumped in MOD (FAO, 2003; Taylor and Francis Group, 2003). Taking all these measures, recent estimates indicate that $4 \%$ of irrigated areas are severely saline, 50\% are of medium salinity, and 20\% are slightly saline (CEB, 2011b). Salinity increase in conjunction with decrease of flow downstream along the two rivers stream has been adverse effects on the agricultural areas which they located in the south of Iraq. This situation generates a resentment and frustration and lead to raise the irritation that might cause a conflict.

\section{e. Economic Development}

The ME is going through a development stage which caused the movement of about $50 \%$ of the population from rural to urban areas. Such movement aggravates the issue of water shortage where water consumption increased about 10 to 12 times its normal per capita as village dwellers (Drake, 2007). 


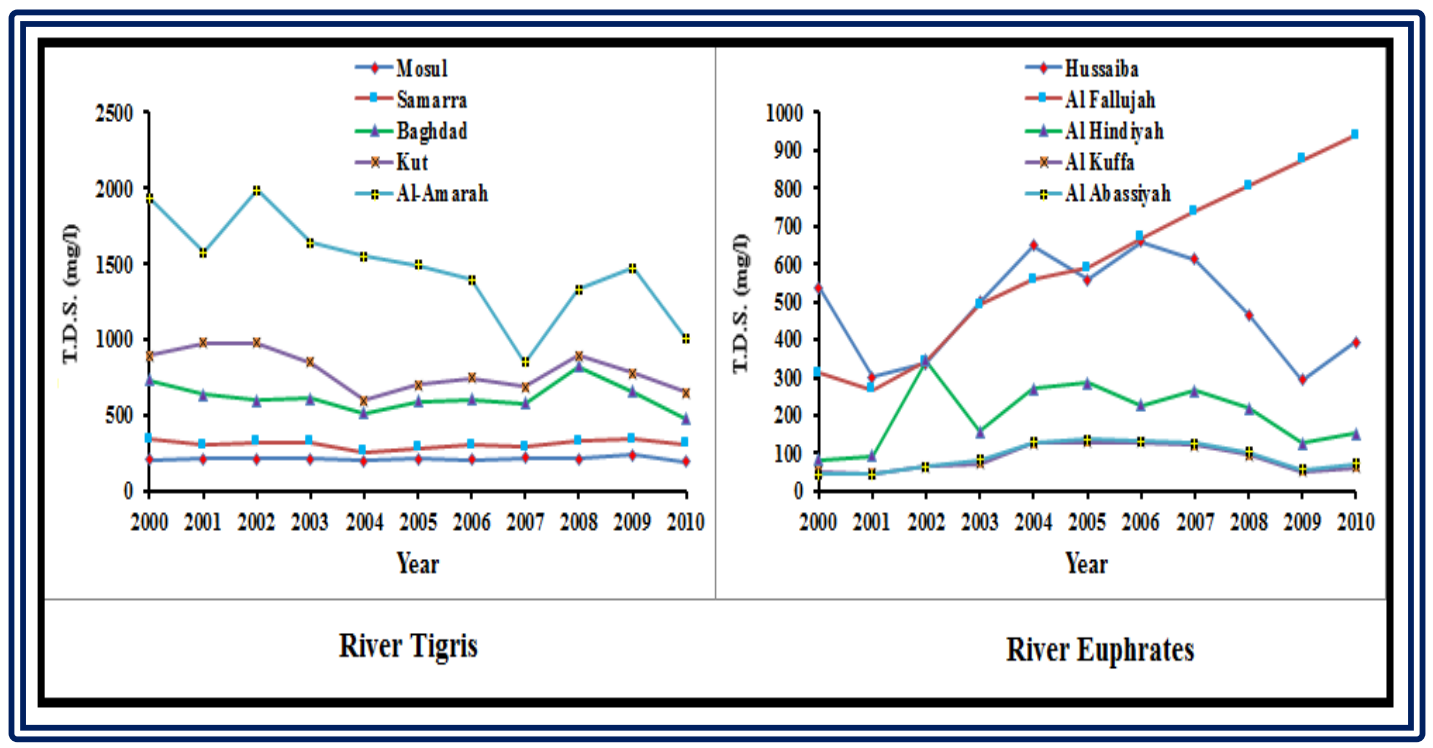

Figure 11: Salinity variation along the Tigris and Euphrates Rivers for the period 2000-2010 (sources of data CEB, 2011a).

Furthermore, the relative fast increase in oil prices caused rapid economic developments and raised the standard of living in Iraq and Syria (Abumoghli, 2015), although the economies of both countries are hardly affected by corruption and the struggle with ISIS in the past few years. The two countries raised their need for water in view of these developments. When the claimed needs for Turkey, Syria and Iraq are added it sum up to $149 \%$ of the total water available (Akanda et.al., 2007). Since Turkey is not considered as one of the countries that produce oil, it is trying to use its water as a commodity for bargaining where in 1992 the Turkish president was announced the ceremony of opening the Ataturk dam that "Neither Syria nor Iraq can lay claim to Turkey's rivers any more than Ankara could claim their oil... The water resources are Turkey's; the oil resources are theirs. We don't say we share their oil resources, and they can't say they share our water resources" (Reed, 2005). Furthermore, Turkey proposed Peace Pipeline and Manavgat River project focus to trade water with Mediterranean and ME neighbors (Kolars, 1994; Martin and Kerids, 2003).

\section{f. Technological Development}

The riparian countries built several dams on the Tigris and Euphrates Rivers and are planning to build more dams. The ME well known with its high temperatures and the construction of these dams have increased the quantity of evaporation from the surface water of the reservoirs. Furthermore, agricultural practices still not modernized where old irrigation methods are still used. Such practices are also leading to high quantities of water losses. Syria exerted efforts to use modern techniques in irrigation systems and it faced plenty of problems (Varela-Ortega and 
Sagardoy, 2003; Friedman, 2013). One of the main problems that farmers were not educated and could not understand and apply the new technologies.

\section{g. Political Fragmentation}

ME was dominated by the rule of Ottoman Empire since the thirteenth century till its defeat and dissolution during World War I. Then the area was divided into different countries, but Britain and France ruled them. During these periods, less conflict took place among the people of this area. Afterwards, the ethnic tendency for the region increased, which contributed to raising the disparities between these country`s people. Consequently, the political and economic competition became more sever and the people more nationalistic. The tension and friction between the United States of America and the Soviet Union and their allies during what is known as the "Cold War" had a restraining impact on the chance of major conflicts, and this does not exist now.

Excessive use of water resources and water pollution became main factors for tension and clash. The 1967 war between Arab states and Israel is an example that reflects this fact where water was one of the hidden reasons. As well as the Israeli occupation of Lebanon in 1982 where they controlled Litany River and diverted its stream. To meet the high-water demand, Israel is extracting $40 \%$ of its water from aquifers beneath the West Bank and Gaza (Drake, 2007). Plenty of dams were built on the Tigris and Euphrates Rivers and their tributaries (Table 1). Unilateral decisions without any consultation with riparian countries also raised friction (Abdullah, 2012). As an example, the tension between Syria and Iraq in 1974 over the Euphrates water sharing. Future prediction models for surface water and groundwater resources show their depleting in the ME (Bazzaz, 1995; Al-Ansari et.al., 1999, 2011, 2012; Chenoweth et.al., 2011; Voss et.al. 2013; ESCWA, 2013; Hamdy, 2013). For these reasons, UN Secretary General Boutros Boutros-Ghali said in 1985 that the next war in the Near East would not be about politics, but over water (Venter, 2008).

\section{h. International Water Laws}

The International Law Commission of the UN worked on the Convention on the Law of the Non-Navigational Uses of International Watercourses for three decades, and it was approved by the United Nations General Assembly on the 8th July, 1997. Three countries voted against this law. These countries were: Turkey, China and Burundi (Elhance, 1999). This convention needs however to be ratified by thirtyfive countries in order to enter into force, which it had not attain hitherto. In this law, the UN stated rights and obligations that states could follow. It also gave the principals and mechanisms that states should follow to avoid dispute escalating to the level of acute conflicts. This law could be adequate for non-arid zones and not for an arid region such as ME (Al-Ansari, 2016). In addition, despite the principals stated, there are no international legal commitments to force the countries to share their water (Morris, 1992). Having this situation, then agreements will depend upon several factors like: the goodwill of the countries which they shared the drainage 
basin, the available internal and external power and the national benefits for the country to keep going to its politics (Jones, 1995).

\section{i. Public Awareness:}

Despite the fact that Syria and Iraq are facing water shortage problems now, it is expected that all countries within Tigris and Euphrates basin will experience the same situation in the future. This is due to increase of population and development in these countries. This implies required improving the present water supply efficiency and demands to fulfill the sustainability through secure the required water for future generations. To achieve such goal, all parties concerned are to be involved (Schaap and Steenbergen, 2002).

A strategy to be adopted to construct a comprehensive public awareness program about water, which comprises promotional and practical activities, and observing and assessing their effectiveness. Al-Ansari (2016) suggested educating the decision makers in the water sector such as water planners, managers and marketers; and the politicians who involve in set the external and internal water policies; and the educators about the significance of water conservation in the sector of potable water supply and how it may be approached. Subsequently, they will be contributed to transfer the benefits of the awareness program into society individuals as a whole. Special syllabus in schools is to be designed to increase awareness for water significance by developing and finding methods to present this subject, and the media should have a vital role in identifying the importance of water issues. Farmers are to be trained on utilize of modern irrigation systems which they are convenient for arid regions since the agricultural sector is the highest consumer of water resources. Using non-conventional water resources should be taken seriously. The public should understand the importance of proper water management. The ignorance of the impact of political and economic decisions of the long-term guarantee of water resources is one of the biggest problems in the ME (Al-Ansari, 2016).

Texas Water Development Board (2010) set a program for water conservation and use that can be adopted by the countries concerned. The main points in this program can be summarized as follows:

- What is the legislation that applied in granting the permits for water and wastewater?

- How is the water produced and distributed?

- What are the methods of collecting and treating the wastewater?

- What are the services, quality and methods of maintenance, which are provided by your utility?

- What kind of customer service does your utility provide?

- What conservation measures are in place?

As an example, it is noteworthy to mention that Iraq is expected to have -20.6 billion cubic meters in 2040 (Figure 12, MacQuarrie, 2004). Such a figure raises the alarm, and action should be taken starting now. 


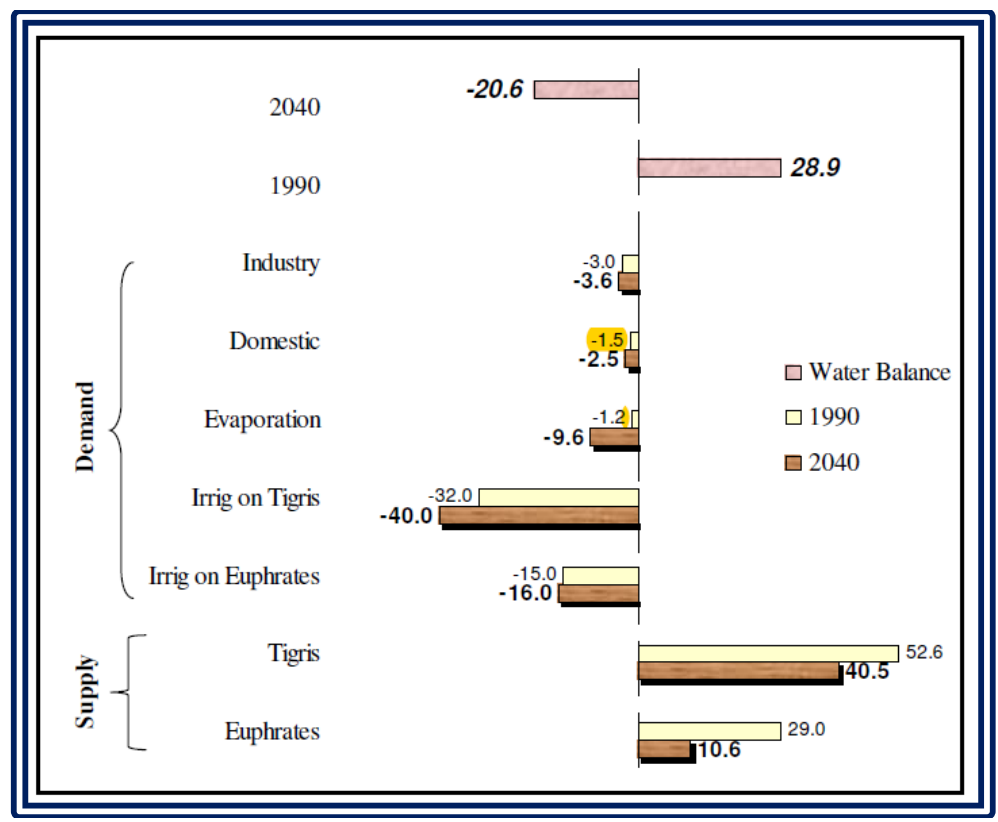

Figure 12: Iraqi Water Balance 1990-2040 (bcm) (MacQuarrie, 2004).

\section{International Agreements}

\section{a. Historical Background}

Turkey, Iran, Syria and Iraq are the main riparian countries within the Tigris and Euphrates basins. Since Syria and Iraq are the downstream countries within the basin, so they are always trying to ensure the required amount of water that can meet their domestic, agricultural and industrial demands. In addition, they consider that these basins as international "watercourses" which should be treated as an integrated entity by all the riparian users. On the other hand, Turkey considers the Euphrates and Tigris Rivers as "trans-boundary Rivers" where both are under Turkish authority until they across the border, and when they united together to form Shatt Al-Arab River then it becomes an international river. In addition, in 1997, three countries voted against the International Law Commission of the United Nation on the law of Non-Navigational Uses of International Watercourses one of them is Turkey. Turkey also considers this is not legally binding because the convention does not apply to them (Gruen, 2000). Furthermore, Tigris and Euphrates Rivers basins are considered as one basin by Turkey according to the fact of formation Shatt Al-Arab River from their gathering, in addition to mass water transfer between the Tigris and Euphrates Rivers via the Tharthar system, while Syria and Iraq suppose that each river had independent basins.

Historically, the Tigris and Euphrates basins were under unitary authority of different empires and colonies (Elhance, 1999). Water issues disputes that took nationalistic character started after the British and French mandates were dissolved. Before World War II, the first signed treaty was in 1913 between Britain, Russia, Iran and Turkey for the regulation of Shat Al-Arab River. France and Great Britain 
as a representıng power for both of Syria and Iraq, respectively, they signed an agreement in 1920 to establish a committee that coordinates the efforts toward the utilizations of the Euphrates and Tigris Rivers (Berardinucci, 2010; ESCWA, 2013). This was followed by two treaties in 1921 where it states in article 12 that Aleppo city can use the water of the Euphrates River. Then in 1923, another treaty was signed between Allied powers and Turkey known as Lausanne agreement concerning the Euphrates and Kuviek Rivers. The treaty also included a provision that Turkey must consult Iraq before undertaking any hydraulic works (article 109) (Berardinucci, 2010; ESCWA, 2013). In 1926, Turkey and Allied powers signed a Neighborly Relations treaty where they agreed to cooperate together to use the Euphrates basin. The commission on the demarcation of the Turko-Syrian Frontier on the Tigris was established in 1930. As a result, a treaty took place between France as a dominant power on Syria from a side and Turkey from another side, which stated that the border between the two countries follow the thalweg principle, establishing the border in the middle of the Tigris, regardless of the changes in the river's stream (ESCWA, 2013).

Iraq declared its independence from Great Britain in 1932. Then, Iraq and Iran placed an agreement in 1937. This was for demarcating their border and regulating navigation in Shat Al-Arab River. Now all the aforementioned treaties have much importance for contemporary interstate relations and geopolitics in the basins (Elhance, 1999, ESCWA, 2013). In the 1946, Ankara Treaty of Friendship and Good Neighborliness was signed by Turkey and Iraq (Beschorner, 1993) and considered as the first bilateral cooperation between both countries regards management the common water resources. The treaty is stipulated that Turkey has the right to install and operate permanent flow measurement facilities and any obtained data should provide to Iraqi side (article 3), as well as inform Iraq with any intention of construct any water projects (Berardinucci, 2010; ESCWA, 2013). Turkey promised that it would not alter the Euphrates flow without informing Iraq, and, to adapt any future works to the needs of both states. In that treaty, Iraq was allowed to construct protection and observation posts in Turkey's territory to prevent downriver flooding (Fadel et al., 2002).

First few hydrological projects began in Iraq in the 1950s where Samarra barrage and Dukan Derbendikhan dams were constructed in Iraq (Kibaroglu, 2008; Berardinucci, 2010). The first meeting between Turkey, Syria and Iraq took place in 1965 where it was decided to demise and end of the treaty system (Bari, 1977). New phase of their relationship took place between the three riparian countries in 1960s when Turkey decided to construct Keban Dam. Turkish and Iraqi experts held a meeting in June, 1964 and in that meeting, Turkey agreed to retain the discharge at the downstream of the dam at a flow average $350 \mathrm{~m}^{3} / \mathrm{sec}$, the natural flow of the river can provide the adequate quantities to maintain the discharge at this average. Turkey proposed establishment of a Joint Technical Committee (JTC). This committee duty is to investigate the rivers to estimate the average of annual discharge for each river and to determine the required water quantities for irrigation for beneficiary countries through joint field studies. The main procedures and 
outlines of the committee works should be documented in order to facilitate an agreement on water rights (Kibaroglu and Scheumman, 2011).

In 1965, a tripartite meeting was held in Baghdad. During that meeting, Iraq, Syria and Turkey demanded 18,13,14 BCM of the Euphrates water annually. This amount exceeds the low annual flow of the Euphrates River. In these meetings, proposed dams were discussed, in particular, Keban (Turkey) and Tabaqa (Syria) Dams. After 22 rounds of talks, it came to a standstill (Daoudy, 2009). One of the main issues that were proposed by Turkey is that it agrees to sign a tripartite treaty only if there was an "inclusive agreement on the distribution of the waters of all the rivers common to it and Syria" (Lowi, 1995). Later, Keban Dam was operating in 1973 and Tabaqa Dam in 1974. This raised very high tension between Iraq and Syria. The latter promised Iraq for a supply of 200MCM from Tabaqa Dam. The tension between Iraq and Syria became very high again in 1975 when Syria started to impound Assad Lake, and Syria denied the Iraqi right in sharing a part of the water of this lake where Syrian side declared that the coming flow from Turkey was less than the normal flow, and they received half the expected quantities of water (Berardinucci, 2010). The Arab League, Saudi Arabia and Egypt tried to mediate and solve the problem, but all their efforts failed and both countries amassed troops along their border in June, 1975. Later, Saudi Arabia suggested sharing the water of the Euphrates between both countries based on the water quantities that received by Syrian from Turkey; this proposal reduced the dispute, but they did not sign any agreement. Turkey expanded the Lower Euphrates Project and its name became Güneydogu Anadolu Projesi GAP), the Southeastern Anatolia Development Project (GAP) in 1977 (Kibaroglu, 2008).

In 1980, both Iraq and Turkey signed a cooperation protocol in technical and economic levels, later on, Syria joined to this protocol. Specifically, in 1983. Issues of regional waters - particularly the Euphrates and Tigris Rivers- were to be discussed by a joint technical committee (JTC). Later, Syria supported the insurgent from the Kurdish and Armenian nationality against the Turkish regime and allowed them to attack GAP projects to have their headquarter in Syria. These rebels were conducting subversive actions on the GAP projects` works (Zawahri, 2006) while, Iraq gave permission to the Turkish troops to carry out their attacks against the Kurdistan Worker's Party (PKK) on Iraqi lands. In 1987, Syria and Turkey signed a protocol for Economic Cooperation. In that protocol, Article 6 reads as follows: "During the filling up period of the Atatürk Dam reservoir and until the final allocation of the waters of Euphrates among the three riparian countries, the Turkish side undertakes to release a yearly average of more than $500 \mathrm{~m}^{3} / \mathrm{sec}$ at the TurkishSyrian borders and in cases when monthly flow falls below the level of $500 \mathrm{~m}^{3} / \mathrm{sec}$, the Turkish side agrees to make up the difference during the following month". In addition, Article 7 of the protocol states that Turkish and Syrian sides shall coordinate their cooperation with Iraq to achieve fair allocation for Euphrates and Tigris water within the less potential time. Article 9 confirms the determination of the two countries to construct a hydropower project and operate the irrigation systems together on both rivers (Zawahri, 2006; ESCWA, 2013). Then Syria and 
Iraq agreed that $58 \%$ of the total water quantities that received by Syrian from Euphrates River would be released to Iraq (Schmandt et al., 2016). Due to the fact that Iraq was ignored and was not asked to sign that protocol, it did not allow Turkey to attack the PKK in Iraq and in 1988, Iraq suppressed its Kurdish uprising in February 1988, 60,000 Kurds fled to Turkey, further deteriorating their relationship (Beschorner, 2008).

Turkey notified its downstream neighbors before November 1989 that it is going to impound Ataturk Dam`s reservoir. It explained the technical reasons behind the action and also provided a detailed program for the replenishment of the losses. In addition, delegations were sent to the region to explain the need for the action, and the measures taken. Impounding started on the 13th January, 1990 and ended to February 13, 1990. January was chosen because the demand for water is low in that month. Official complaints against this action were registered by Iraq and Syria and called for a new agreement to share the waters of the Euphrates River. They also agreed that $58 \%$ of the Euphrates water that Syria receives would be provided to Iraq (Kibaroglu and Scheumman, 2008). Iraq and Syria protested against the construction of Birecik Dam in Turkey, which raised friction and tension again in 1996 (Kibaroglu and Scheumman, 2008). In view of this situation, Iraq and Syria organized a joint water coordination committee to face water shortage problems. They agreed that Tigris and Euphrates water can be used in an equitable, reasonable sharing and utilization. To resolve the conflict, Turkey asked Syria in May, 1996 to engage in talks, and it suggested that water can be divided according to the area of cultivated lands while Syria asked for equal share (Wolf, and Newton, 2008), consequently, no agreement was reached. Syria continued to support the Kurdish rebel group (the PKK) to attack southeastern Turkey from Syrian soil. Turkey retaliated to this 1987act in October, 1998 and asked Syria to stop supporting terrorists immediately, which was understood as a threat of military intervention. Syria responded to Turkey, and they signed what is known as the Adana Accord. Accordingly, the relationship between the two countries improved, and they signed another agreement in 2001 between GAP's Regional Development Administration (GAP RDA) and General organization for Land Development (GOLD) (Berardinucci, 2010).

In 2002, Syria and Iraq signed an agreement which allows the former to establish a pumping station on the Tigris River. Project area and volume of water extracted was specified in that agreement (ESCWA, 2013). Later in 2007, Turkey and Syria reactivated the JTC and held a series of meetings during which they agreed to share information on meteorological patterns and water quality. The amount of water that Turkey released to Syria and Iraq was affected by the drought that was experienced in the region through the period 2007-2009. In 2009, Turkey and Syria signed a new agreement known as "Strategic Cooperation Council Agreement" and number of MoUs were signed. All the signed agreements focused on emphasis on improvements to water quality, the construction of water pumping stations (on the Syrian stretch of the Tigris) and joint dams, as well as the development of joint water policies (ESCWA, 2013). Turkey assisted Iraq through that period with 
additional water, but they did not sign any agreement (Jones, 2009).

Some of the tributaries of the Tigris rises in Iran and as far as Shat Al-Arab, is concerned, the two main riparian countries are Iraq and Iran. In this context, the first agreement was signed in 1913, which is known as the Constantinople accord concerning borders delineation between the two countries which dealt with continuous shifting of the river watercourse. This was followed by another agreement in 1937 signed with support from the League of Nations. According to these agreements, Iraq has the full sovereignty over the two banks of Shat Al-Arab River, although Iran kept claiming half of the river to its sovereignty. Iran supported the Kurdish rebels in north of Iraq during the 1970s so that it can exert pressure on Iraq to negotiate the Shatt Al-Arab status. In 1975, an agreement was signed in Algeria between the two countries. As a consequence, Iraq to concede its right in half the Shatt Al-Arab and the Kurdish rebellion was ended (US Department of State, 1978). Iraq felt that it was humiliated, and continuous strain started to increase till first Gulf war started between Iraq and Iran in 1980. The war ended without resolving the problem of Shat Al-Arab (Wallas, 1998). Till now, all Iraqi governments kept the strong position that Iraq would never reinstate the 1975 agreement.

The improved relationship between the two countries after 2003, had led the Foreign Ministers of the two countries to meet and discussed among other things the Shatt Al-Arab issue in 2014. Both parties agreed to move forward and work on the marking of land borders and to implement agreements in accordance with the borders` treaty, protocols and agreements that were signed between the two countries in 1975 (Dinar Advice Guru, 2014). This is very important because Iran has done several things that affected the water resources`situation in Iraq (Abdullah, 2012) which can be summarized as follows:

- Dam was built on Wand River in 1960, and as a result Khanaqeen city was cut from its water resource. Three more diverting dams were built on the same river later.

- Diverting Serwan River waters which is one of the tributaries of Diyala River.

- Dams were built on valleys near the border with Iraq to divert the water inside Iran.

- Building dams on Karkha River.

- Water projects on Karun River and diverting its water inside Iran.

- These acts caused considerable hardship to the Iraqi population in general and to the inhabitants of border areas, in particular; such as Khanqeen, Mandli, Badra and Jassan and lately to Qalaa-Diza, Halabja, and Shir-Zur in Iraqi Kurdistan Region. 


\section{b. International Law and Water Sharing Issues}

Disputes concerning water resources of the Tigris and Euphrates Rivers between riparian countries seriously started in the 1970s when some of the riparian countries started to build dams on these rivers and the effect of droughts that dominated the region. Each country has its own justifications and explanations to the laws concerned, which are the International Water Law, the Helsinki Rules (ILA Helsinki Rules, 1967), Berlin Rules (ILA Berlin, 2004) and the UN convention on the law of the None Navigational uses of International Water Courses (UN, General Assembly, 1997). These laws are based on restricting the territorial sovereignty of any riparian state to the part of an international freshwater system that is located on its territory, and the riparian State has to respect the right of the other riparian states to utilize the system.

In addition, they approach the problem through the theory of community interest, and the theory of limited sovereignty to reflect the interdependent character of freshwater systems. In view of these theories, two provisions are to be considered. These are the doctrines of equitable utilization implying fairness and reasonable use and the rule of causing no harm. Therefore, riparian states should recognize the limitation imposed by the hydrological cycle (i.e. planned amount of water withdrawal from a freshwater system does not exceed the amount it receives through the hydrological cycle), and the water should be capable of regeneration to the hydrological cycle, i.e. not polluted, (Bremer, 2013).

Syria and Iraq claim that Turkey is having water more than it needs, and they would like to have more water to secure the water demand for their uses. Turkey claims that this is not correct because out of $180 \mathrm{BCM}$ of the annual runoff, only $110 \mathrm{BCM}$ of water is usable and 25.9 BCM can be made available. These figures are based on considering technological, topographical and geological reasons and this makes this resource unavailable sometimes (Tomanbay; 2000 Yuksel; 2015 and Oei and Siehlow, 2016). When allocation of water per capita is considered (Table 2), it should be noted that these figures will change due to population growth rates (Table 3 ) and effect of climate change.

Historic rights for the use of water of the water of the River Euphrates were claimed by Syria and Iraq. The Turkish response was rejecting these claims where according to Helsinki rules; Articles I and V (ILA Helsinki, 1967) acquired rights can only be considered if it is based on equitable use for socioeconomic, geopolitical and hydrological factors, in addition to the avoidance of unnecessary waste in the utilization of waters of the basin. Furthermore, Turkey always accuses Syria and Iraq for using old irrigation techniques and wasteful water management procedures. Turkey suggested a three-stage plan for the technical talks of the three riparian countries to solve the water allocation problems (Centre for Strategic Research, 1996).

Allocations and determining the demands for each country are to be based on: 1) assessment of available water resources 2) conducting inventory studies of available land resources and 3) improving irrigation practices to determine their economic viability. This plan was based on two premises. These are to consider the Tigris and 
Euphrates Rivers as one transboundary water course and secondly is that water requirements are to be based on scientific studies of the needs of that country. Iraq and Syria rejected this plan where they considered it as being vague and gives advantages to Turkey and fringes on the sovereignty of the riparian states. In addition, Turkey considers the two rivers form one basin and deficiency of water in the Euphrates can be avoided by transferring water from the Tigris to the Euphrates via Tharthar canal. Iraq rejects this idea and considers the two rivers in geographically separate basins. In any case, this idea of a single basin is not valid any more after the construction of Ilisu Dam and the effect of drought due to climate change, which has been experienced recently.

Syria and Iraq accuse Turkey of ignoring the "causing no harm" doctrine defined in article X of the Helsinki Rules (ILA Helsinki, 1967), and article 16 of the Berlin Rules (ILA Berlin, 2004) in addition to article 7 of Part II of the UN convention on the law of the None Navigational uses of International Water Courses (UN General Assembly, 1997). This claim is based on the fact that Turkey is reducing the share of other riparian countries by implementing the extensive GAP project. This is damaging the agricultural practices both in Iraq and Syria as well as municipal water and health sectors. Therefore, the project has negative influences on the people and the environment where the quality of water is deteriorating. It is noteworthy to mention that Iraq is the most negatively affected country due to impounding of dams both in Turkey and Syria as well as water quality deterioration.

Finally, it should be stated that Syria and Iraq with the occupation of ISIS parts of these countries, the water issue is not considered as a priority now in view of the present situation.

\section{Discussion}

Countries in the ME suffer from the water shortage problem. This has caused tension and friction and sometimes escalated leading to war between countries in the region. The Tigris and Euphrates Rivers are considered as a very valuable source of water for the riparian countries within the basins of these rivers. Four main countries (Turkey, Syria, Iran and Iraq) utilize the water of Tigris and Euphrates basins and have never reached an agreement to share the waters of these rivers and their tributaries. These countries never reached to an agreement to share the water of these rivers where all of them claim that water is scares and water is over exploited (Smakhtin et.al., 2004; Aydin and Ereker, 2009; UN, 2013) or extremely highly stressed (Aydin and Ereker, 2009; Reig et.al., 2013). Water Dependency Ratio index shows that Turkey has $1.0 \%$ dependence followed by Iran $(6.56 \%)$, then Iraq $(53.45 \%)$ and finally Syria (72.36\%), Figure 13 (ChartsBin, 2018).

Article 6 (1) from the United Nation International Law Commission UN/ILC law reveals that any user of water has exactly the same priority, and this mean that all have equal weight. Using this concept, MacQuarrie (2004) analyzed the existing data for the basins of Euphrates and Tigris. The results of the analyses showed that in terms of water needs, Iraq recorded as the lowest between the three countries 
(1.94). However, slightly lower than Syria by small portion. Therefore, Syria is considered as second (2.0) and Turkey (2.06) is the third. The results revealed that the differences were insignificant that each riparian country had approximately same share from Euphrates waters. According to the fact that equal ranking was used in the analyses, MacQuarrie (2004) thinks that this method is not unrealistic because it is an effective analysis tool for some countries. While it is useless for other countries. Then, MacQuarrie (2004) introduced three main factors. The first is priority need, and the second was the Water Security factor, and the third is the environmental factor. As an example of the first factor, MacQuarrie (2004) argued that Syria would exceed their social demand, as Turkey's ambitions for use the water resources for generating the energy would overcome its desire for provide water for irrigation. The results of the water security factor which based on take this factor into account depending on the analysis from the previous work showed that all riparian countries have equal ranking. As far as the results of the environmental factor (which was added to the hydrological category) are concerned, he found that as a result of polluted the water of Euphrates and Tigris from the effluent which is come from agricultural lands, Turkey starts to lose its superior position, and this against Article 7 and the principle of 'no harm'. The final conclusion on the application of the United Nation International Law Commission UN/ILC regarded the concept of equitable and reasonable utilize as a manner to manage and allocated an international (or transboundary) watercourse system, this principal inapplicable in the situation of Tigris-Euphrates.

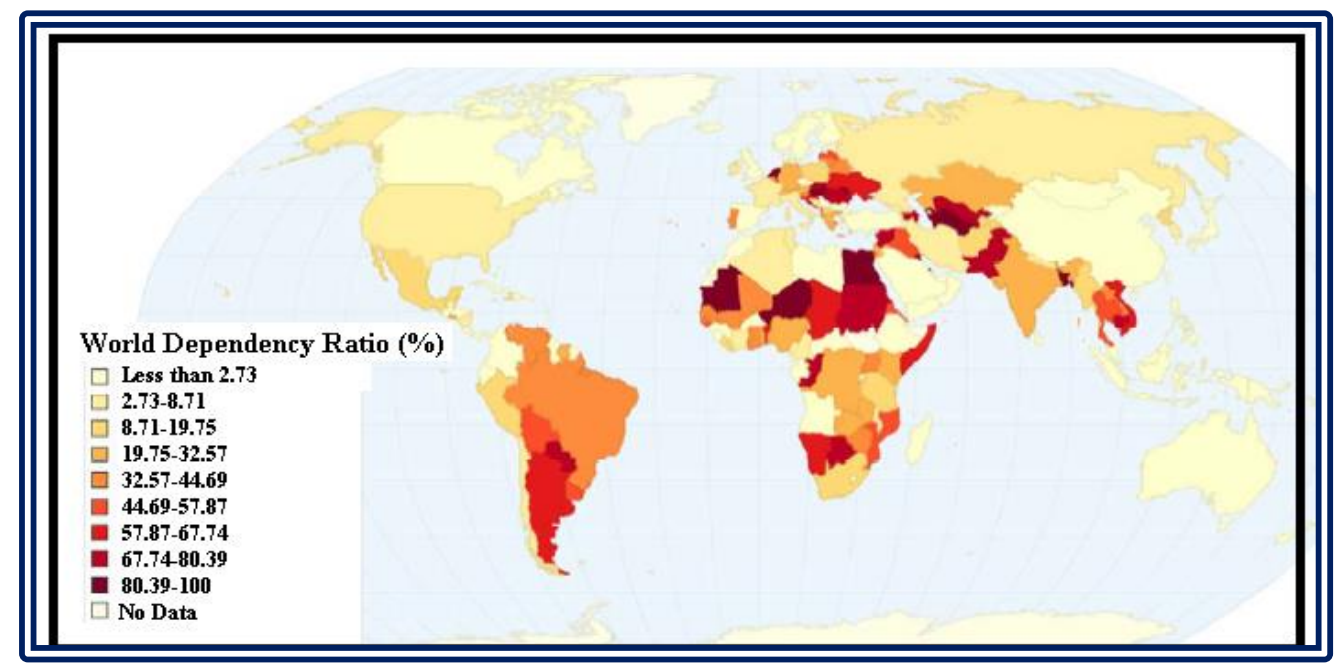

Figure 13: World Dependency Ratio (\%) (modified after ChartsBin, 2018). 
This is due to the following reasons:

- The information exchange and data sharing were very low or does not exist.

- National interests are set the utilization priorities. However, the political issues. Specifically, security concerns where they are dominated over the others issue such as economic and social priorities. The framework of water policies fails to cover other aspects like water, environmental, human and ecological security.

- The suggested framework is reasonable to achieve the cooperation between the involved countries. However, they have no motivation to make it applicable. Especially, Turkey supposed to get losses as Turkey is represent the upstream land. Turkey will not be punished for lack of commitment UN/ILC law because there is no penalty for not meeting it.

In the absence of inclusive agreements and low cooperation, regarding attains the fair sharing for the water resources, individual countries took unilateral steps and implemented projects that led to deterioration the water quality of the whole basin and minimize its local and agricultural benefits. The outcomes of previous negotiations were revealed a few frameworks for basin sharing. However, most of these frameworks stilled without documented agreements. It should be mentioned however, that Turkey exerted some efforts to cooperate. These efforts were primarily concentrated on developing and improving southeastern Turkey (GAP project) where it reduces the dependence on importing oil by seeking for economic development through invest its water abundance (Berardinucci, 2010).

It is noteworthy to mention that there are also political factors and military events that are involved in this conflict (Berardinucci, 2010). Example of these political factors is the problem between Turkey and Syria because of Hatay Province. France granted Turkey the permission to take control on this province in 1939. In addition, Syria's supports to the PKK (Berardinucci, 2010). As an example of military events is the conflict that happened in 1975 over the Tabqa Dam, when both Iraqi and Syrian regimes sent military forces to their shared border. In the same contest, Syria granted the PKK part from the Syrian lands, so that they act as a proxy so that they could attack the Turkish locations. Specifically, the strategical hydrological projects. Without any militarily responsibility on Syria (Berardinucci, 2010). Of course, one should also bear in mind that the eight years' war between Iraq and Iran was because of the sharing of the Shatt Al-Arab watercourse.

It is evident that Turkey's position is strong in comparison with Iraq and Syria as mentioned above that Turkey represent the upstream lands for Tigris and Euphrates Rivers. Due to this fact, as the regional hegemon and the upper riparian, the cooperation is the last thing that Turkey wants. The only factor that makes Turkey accept to negotiate with Syria and Iraq is to avoid any negative criticism from UN or EU and US. Otherwise, Turkish government not serious to cooperate with them. Furthermore, there is no harm by further meetings and discussions. Under the current weak status of Syria and Iraq, it is evident that Turkey is taking advantage and will keep controlling the waters of the Euphrates and Tigris Rivers, and Iran will do the same for the tributaries of the Tigris and Shatt Al-Arab Rivers; Turkey and Iran try to force their plans on Iraq and Syria regardless the consequences. In 
addition, both Turkey and Iran have the advantage of their geographic position being the upper riparian countries and having relatively the strongest economic and political power in the region which will authorize them to secure any water quantities they desire.

Due to the fact that Syria and Iraq are very much involved in security issues now, Turkey and Iran will remain the riparian hegemons for a long time due to their power and dominant river positions. Water shortage problem is not of prime importance for Syria and Iraq till they solve the ISIS problem but sooner or later, they will try to get their water requirements. To resolve this conflict, a strong and influential mediator is required to bring all parties to the discussion table. Such mediator can be USA, EU or World Bank that can bring the riparian countries to the negotiation table. To give incentives to upper riparian countries to cooperate, other matters can be included in the negotiations such as supplying Turkey with gas and oil from Syria and Iraq for reduced prices. Another important step is required to be implemented by Syria and Iraq is setting a long-term strategic plan for the management of their water resources. Such plan is to be implemented irrespective of the changes in the external or internal politics and should be based on "Resources Dependence Theory". This theory assumes that the good human resources, finance and information as well as good international relations exist (Pfeffer, 1987; Pfeffer and Salancik, 1978; Hillman et.al., 2009; Harkins and Forster-Holt, 2014).

\subsection{National Problems Supply and Demand}

Despite the differences in numbers given by various sources, there is an overall agreement that there is a gap between supply and demand (Al-Ansari and Knutsson, 2011; UN, 2010; World Bank, 2006). The overall estimate of water required is 75 to 81BCM (World Bank, 2006). Irrigation consumptive use reached 39 BCM in 1991 and in 2003/4 it was 22 BCM equivalent to 44 BCM of water derived, assuming $50 \%$ irrigation efficiency. Real efficiency might be $25-35 \%$ (World Bank, 2006). The agricultural land cropped is about 1.9 million ha in recent years out of 3.5 million ha. If all this area is cropped then the water requirement is 50BCM assuming good irrigation efficiency.

The demand from the sanitation sector is about $5 \mathrm{BCM}$ and due to the fact the infrastructure system is out of service, losses have increased. It should be mentioned however, that the demand of the industrial sector decreased. Hydropower use including the evaporation from reservoirs reaches 10BCM/annum. Restoring the marshes requires $16 \mathrm{BCM}$ and demand for in- stream flow reaches $3 \mathrm{BCM} / \mathrm{annum}$. UN (2010) and Stockholm International Water Institute (SIWI, 2009) estimates indicate that available water in Iraq reaches $75 \mathrm{BCM}\left(2,400 \mathrm{~m}^{3}\right.$ per person per year which is more than neighboring countries with the exception of Turkey) (Figure 14). 


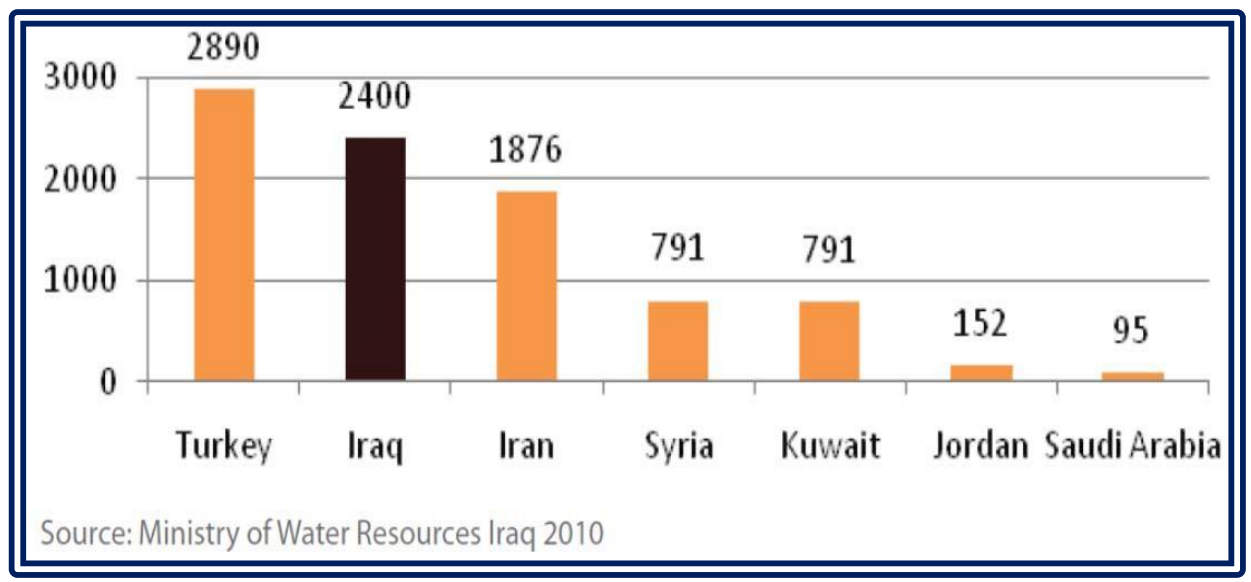

Figure 14: Water allocation in some MENA countries.

The overall water demand excluding restoring the marshes is about $73 \mathrm{BCM}$ and the available water is about 59-75 BCM. If the situation remains as it is the Iraqi water supplies will drop to 43 BCM by 2015 and to 17.61 in 2025 (UN, 2010) and the demand is 66.85 BCM (IAU, 2011) or 77BCM (Investors Iraq, 2009).

It should be noted however that the quality of water deteriorates from north to south along both the Tigris and Euphrates Rivers where it approaches a salinity of about $2000 \mathrm{mg} / \mathrm{l}$ in Basra (IMMPW, 2011). According to the World Bank (2006), the Iraqi water deficit in 2030 will reach $25.55 \mathrm{BCM}(37 \%)$ where the expected supply is 44 BCM only. Recent reports state that the Tigris and Euphrates rivers will be completely dry by 2040 (UN, 2010).

The supply of fresh potable water is essential to life, socioeconomic development, and political stability in the region. It was reported that one cubic meter of water can provide drinking water for one person for one year or the same quantity can produce only one $\mathrm{kg}$ of food grain when used for irrigation in a dry climate (Perry and Bucknall, 2009). The need for a rationalized holistic management of this most vital natural resource is paramount in order to attain a sustainable society. Since the largest consumer of water across the region is agriculture which accounts for $66 \%$ of demand, (Hiniker, 1999) and therefore the water shortage problem cannot be objectively analyzed nor adequately addressed without a thorough consideration of agriculture in the region (Sadik and Barghouti, 1994). For example, an approximate 10 percent transfer of water away from agriculture would produce a 40 percent increase in domestic water supply for Jordan (Sadik and Barghouti, 1994). Postel (1992) argues that rather than diverting precious water to agriculture this water could be saved by importing the food/grain. However, this is not the case in many Middle Eastern countries which have unrealistic aspirations of food self- sufficiency and in it would require a most fundamental change in national outlook (Charrier and Curtin, 2007). Sadik and Barghouti (1994) emphasized that the extent of the problem is so severe that "the future challenges in meeting the growing demands for water are beyond the capabilities of individual countries". Mitigating supply 
shortfalls could be achieved re- allocation of current agricultural supplies (Rogers and Lydon, 1994).

\section{Distribution Network}

Water usage in Iraq is about 350 liters/capita/day (IMMPW, 2011). Safe water supplies used to reach $100 \%$ and $54 \%$ of the urban and rural areas in 1991 . The situation deteriorated in both quality and quantity afterwards and $33 \%$ of the population do not have access to safe water and sanitation (Al-Ansari and Knutsson, 2011; IMMPW, 2011). Current estimates indicate that water supply to urban areas is $73 \%$ and in rural areas $40-45 \%$ of requirements. Water services are limited to a few hours per day and it is of poor quality. Multiple Indicator Cluster Survey (MICS) (2007) indicated that $79 \%$ of the population has access to drinking water $(92 \%$ in urban and $57 \%$ in rural areas). It was also stated that those having access to drinking water it takes about 21 minutes in urban areas (42 minutes in rural areas) to get to the source to bring water for $17 \%$ of all households. The same survey showed that $21 \%$ have no access to drinking water, and $16 \%$ have daily problems while $7 \%$ have weekly problems, $15 \%$ have less than weekly problems and only $41 \%$ have a reliable source. According to IMMPW (2011) domestic water shortage is 1.7 $\mathrm{MCM} /$ day but if the percentage per capita is decreased, there will be excess water (Table 5).

The demand is about 11 million cubic meters per day while the supply is half that amount (IMMPW, 2011). The Iraqi government hopes to ensure water supplies to $91 \%$ of the population by 2015 (UN, 2010). The scenarios given by IMMPW (2011) are based on lower ongoing consumption level (Table 5). The efficiency of the distribution network is very poor (32\%) (World Bank, 2006) and it is deteriorating with time. For this reason, water allocation per capita has been decreasing with time since 1980 (World Bank, 2013). These figures are considered very high compared to developed countries where it is about 10\% (Stephen and Brooks, 1994, Sharma, 2008). There is no international unified recipe to reduce water losses that can be applied or used. Several different methods can be used to reduce the losses. This depends on several factors; the most important is the technical conditions, and economic potential of the Water Authority, in addition to the desirable size of the reduction in losses. This problem of overcoming the water losses is the most important problem facing all countries without exception.

The strategy for reducing water losses depends directly on the management techniques used in the water sector. Before thinking about finding new water sources or establishing new pumping stations or drilling of new wells to meet the growing water needs, we must think how we can draw on all the capabilities and potential to reduce water losses. This will provide significant quantities of water that already exist within the network to the public. It does not cost a lot of either effort or funds or require extra extraction, processing, distribution and transport. To reduce the losses, we have to secure the economic base, technical competence administrative structures. Therefore, there are many of the administrative, technical 
solutions and economic measures that can be adapted to solve the problem. Al-Ansari et.al. (2013c) suggested several measures to decrease water losses in the water supply networks in Jordan. These measures can well be applied in Iraq. These measures can be summarized as follows:

\section{A. Administrative measures:}

These measures are as important as technical measures to reduce water losses. A secure economic, well qualified and efficient administrative and technical staff can greatly improve the administration of the water authority. This can be achieved by:

1. Setting a special law and regulations for the water authority. This will improve the action of the authority.

2. Restructuring the water authority. Although the water authority enjoys the independence on financial and administrative levels, but its budget is subject to the procedures and provisions that apply to any ministry or government department. The water authority should be restructured on the basis of actual financial and administrative independence, without the intervention of governmental entity, and therefore will allocate the money necessary to overcome the water losses and can have a good selection process to get highly qualified staff.

3. Granting other water departments of the Water Authority the required autonomy in the implementation of water projects and make decisions that work to reduce water losses.

4. Improving the internal administrative staff by selecting highly qualified and trained personnel.

5. Financial incentives should be used to encourage staff to increase productivity. Intensive training programs should be implemented for the rehabilitation of the staff as well as to training them using international experts and try to learn from experiences of developed countries.

6. Reconsidering consumers contracts so that they hold the responsibility of excessive unjustified water wasting and be subject to the issue of accountability and trial for illegal water use. Each consumer should have a file. In this file full information about the consumer (e.g. monthly consumption rate, number of family members, annual income, un-served area, and type of water use) and the documentation of the public network on the ground. Under charts and maps mounted with locations and type and size of pipes, fittings and knowing conduct of the pipeline and that part buried in the ground to avoid long time search through the site for waterproofing, in order to speed in finding water losses in the cases of faults for maintenance and repair and that will reduce water losses. 


\section{B. Technical Measures:}

1. New technologies should be adopted in finding covered (under surface of ground) seepages or leakages.

2. The life span of the water supply network should be considered.

3. Human capacity building program is to be adopted for workers in the maintenance of public networks on scientific grounds, through the provision of qualified technical personnel.

4. Providing suitable methods and materials for maintenance. Maintenance groups should work round the clock to repair leaks and monitor the distribution network.

5. Periodic maintenance of the water counters at home should be carried out and protecting these counters from adverse weather (e.g. major waves of snow).

6. Adopting the idea of pumping water to water central tanks, and then to the public network, rather than direct pumping to the network which requires high pressure. High pressure reduces the accuracy of the counters, and potential damage to the network. In addition, it will avoid the destruction of counters and leakage of weak sites in the public network.

7. Discontinuous pumping of water to the public network should be avoided because it helps to form a rusty layer in the metallic parts of the water counters and the pipes of the network.

8. Water meters should be installed in accessible locations so that water authority personnel can monitor them and pinpoint any illegal acts to bypass these counters.

\section{Economic Measures:}

1. The water authority should adopt water demand management, which includes direct and indirect actions to monitor water use that affects the behavior of the consumer. This includes financial incentives, and public awareness. Such programs are considered as of low-cost projects, but they are effective in reducing water losses.

2. Public awareness programs should be adopted and should address all the public sectors. Internal and external monitoring teams should be established to monitor performance. Water quality and economic distribution methods should be adopted. These teams should monitor all systems of accounting, financial conditions, legal and the economic situation of the authority and check monthly and annual reports. They should set highly effective economic and financial indicators to measure the performance level of the water authority.

3. Water prices should be set on the basis of the overall cost. It is assumed that the revenues from the water should cover the cost of production. Restructuring of water rates on the basis of total cost of production will reduce the losses, in addition to the reduction of unjustified water consumption.

4. Privatization of some of the duties of the water authority will raise the performance in the water sector. As an example, the monitoring and maintenance operations could be given to the private sector. 
Table 5: Scenarios of domestic water availability and demand (source of data: IMMPW 2011).

\begin{tabular}{|c|c|c|c|c|}
\hline $\begin{array}{c}\text { Water Usage } \\
\text { (liters/capita/day) }\end{array}$ & $\begin{array}{c}\text { Population } \\
\text { (millions) }\end{array}$ & $\begin{array}{c}\text { Water demand/Day } \\
\text { (million cubic } \\
\text { meters) }\end{array}$ & $\begin{array}{c}\text { Water supply/Day } \\
\text { (million cubic } \\
\text { meters) }\end{array}$ & $\begin{array}{c}\text { Balance } \\
\text { (million cubic } \\
\text { meters/Day) }\end{array}$ \\
\hline 350 & 24 & 8.5 & 6.8 & -1.7 \\
\hline 250 & 24 & 6 & 6.8 & 0.8 \\
\hline 200 & 24 & 3.6 & 6.8 & 3.2 \\
\hline
\end{tabular}

The Construction, housing, services and Education Sector (CHSE) (2010) indicated that 245 water supply stations in addition to 2128 water units are in operation with a total water capacity of 7.2 million cubic meters per day. The actual required quantity is 9.8 million cubic meters per day required by about 22 million inhabitants. The water deficit is 2.6 million cubic meters per day $(23 \%)$ and the served inhabitants are only $77 \%$ of the total.

CHSE (2010) report summarized the obstacles facing this sector as:

1. Low allocated budge in the investment plan.

2. Some citizens are using the land earmarked for water projects.

3. Lack of cooperation with various municipals at the governorates in allocating the required land for water projects.

4. Difficulties in transporting of chlorine due to unsafe environment.

5. Lack of cooperation of between the water authorities and the municipal in the districts at different governorates regarding the allocation of land for new water projects.

1. Electricity cuts causing difficulties in the operation of the projects.

2. Decrease of water levels in rivers and low rainfall.

3. Water losses and pollution caused by illegal water use.

4. Increase of construction materials.

5. Complex routine to import the required materials.

6. Low allocations in the operational budget to buy the required quantities of oil.

7. Lack of engineers and technical staff.

8. Intervention of councils in the governorates in water authorities' work.

The allocated budget for several years is considerably low (Table 6) and the expenditure is low as well. This indicates that the progress of the projects is low. The overall number of projects is 245 and there are 2128 water units. These projects and units are run by a staff of 17,125 (see details in table 7). It seems that the actual production is $83 \%$ of the available energy while this in turn forms $88 \%$ of the designed energy (CHSE, 2010). Future projects for the period 2010-2014 were set by the Iraqi government as follow:

1. Executing Resafa water project in two stages with a capacity of $910,000 \mathrm{~m}^{3} /$ day.

2. Announcing the remainder three remaining projects of Resafa water which is supposed to produce $3,165,000 \mathrm{~m}^{3} /$ day. 
3. Establishing new water purification projects for areas remotely located relative to the existing water projects.

4. Establishing small water purification units for areas that suffer from water scarcity.

5. Renewing the water supply networks and establishing new networks for new constructed housing areas and improving the water distribution.

6. Creating 10 new ground reservoirs and the expanding the existing currently operating reservoirs.

7. Construction of new labs and expanding the existing labs.

Table 6: Budget allocated for the period 2004-2008 in Iraqi Dinars ID.

\begin{tabular}{|c|c|c|c|c|c|c|c|c|c|c|}
\hline Allocations & \multicolumn{2}{|c|}{2004} & \multicolumn{2}{|c|}{2005} & \multicolumn{2}{|c|}{2006} & 2007 & \multicolumn{3}{|c|}{2008} \\
\hline & $\begin{array}{c}\text { Region } \\
\text { Development }\end{array}$ & Investment & $\begin{array}{c}\text { Region } \\
\text { Development }\end{array}$ & Investment & $\begin{array}{c}\text { Region } \\
\text { Development }\end{array}$ & Investment & $\begin{array}{c}\text { Region } \\
\text { Development }\end{array}$ & Investment & $\begin{array}{c}\text { Region } \\
\text { Development }\end{array}$ & Investment \\
\hline Allocation & 66 & 0 & 45 & 0 & 105 & 0 & 105 & 45 & 88.9 & 43.252 \\
\hline Spent & 66.063 & 0 & 7.162 & 0 & 32 & 0 & 32 & 24 & 88.9 & 22.8 \\
\hline $\begin{array}{l}\% \text { disbursed } \\
\text { to allocated }\end{array}$ & 70 & 0 & 16 & 0 & 31 & 0 & 31 & 53 & 100 & 66 \\
\hline Total \% & \multicolumn{2}{|c|}{70} & \multicolumn{2}{|c|}{16} & \multicolumn{2}{|c|}{68} & 37.33 & \multicolumn{3}{|c|}{73.33} \\
\hline
\end{tabular}

Table 7: Staff running water projects in all governorates.

\begin{tabular}{|l|c|c|}
\hline \multicolumn{1}{|c|}{ Type of staff } & Males & Females \\
\hline Managers & 15 & 0 \\
\hline Highly skilled & 411 & 405 \\
\hline Technical staff & 1561 & 558 \\
\hline Supervisors & 5,496 & 420 \\
\hline Skilled and semi-skilled & 6,829 & 1,520 \\
\hline Total & 14,222 & 2,903 \\
\hline Overall total & \multicolumn{2}{|c|}{17,125} \\
\hline
\end{tabular}

Projects to be executed require more money allocations where the existing allocations (Table 6) are considerably low for such projects. Budget allocated in 2013 was 1,479,165,000 US Dollar for sanitation and water supply systems, which makes $2.76 \%$ of the overall Iraqi budget. The above total projects in all the governorates are 92 with an approximate cost of 3,630,000,000 US Dollars. The ultimate goal of the Iraqi government is to increase the water allocations to be 450, 360 and 250 L/day/capita in big cities, small towns and villages respectively. In addition to the allocation of the required budget, there are other required items to be prepared. Such items includes maintaining the electrical power required for the projects, maintaining the required fuel to run the projects, human power required are to be appointed, availability of water in the Tigris and Euphrates for the water projects and construction of central projects (Strategic) for water supply. 


\subsection{Sanitation}

About $92 \%$ of the population of Iraq is living in households using improved sanitation and $82 \%$ of this category use flush toilets connected to sewage systems or septic tanks or latrines, Figure 15 (MICS, 2006). Improved sanitation is $98 \%$ and $82 \%$ in urban and rural areas respectively. Only $48 \%$ have their toilets connected to pipe sewer systems in metropolitan areas, $57 \%$ have septic tanks in urban areas and $36 \%$ flush their toilets to latrines which is very common in rural areas. In reality, most of the of the sewage treatment plants and septic systems do not function properly and as a result there is an overflow of the effluent into the environment (UNICEF, 2003).

Only 14 cities out of 252 urban centers have a wastewater treatment plant (World Bank, 2006). Wastewater treatment capacity reaches 350,000 cubic meters per day and this serves $8 \%$ of the population. Most if not all the sewage and sewerage systems require replacement, rehabilitation and upgrading. It should be mentioned however that $70 \%$ of the sewage water is discharged untreated directly to rivers (World Bank, 2006). Damaged waste-water systems and drinking water networks are causing mix of water and as a result many people are infected by sewage related diseases (World Bank, 2006; MICS, 2006; UNICEF, 2003; Relief web, 2003).

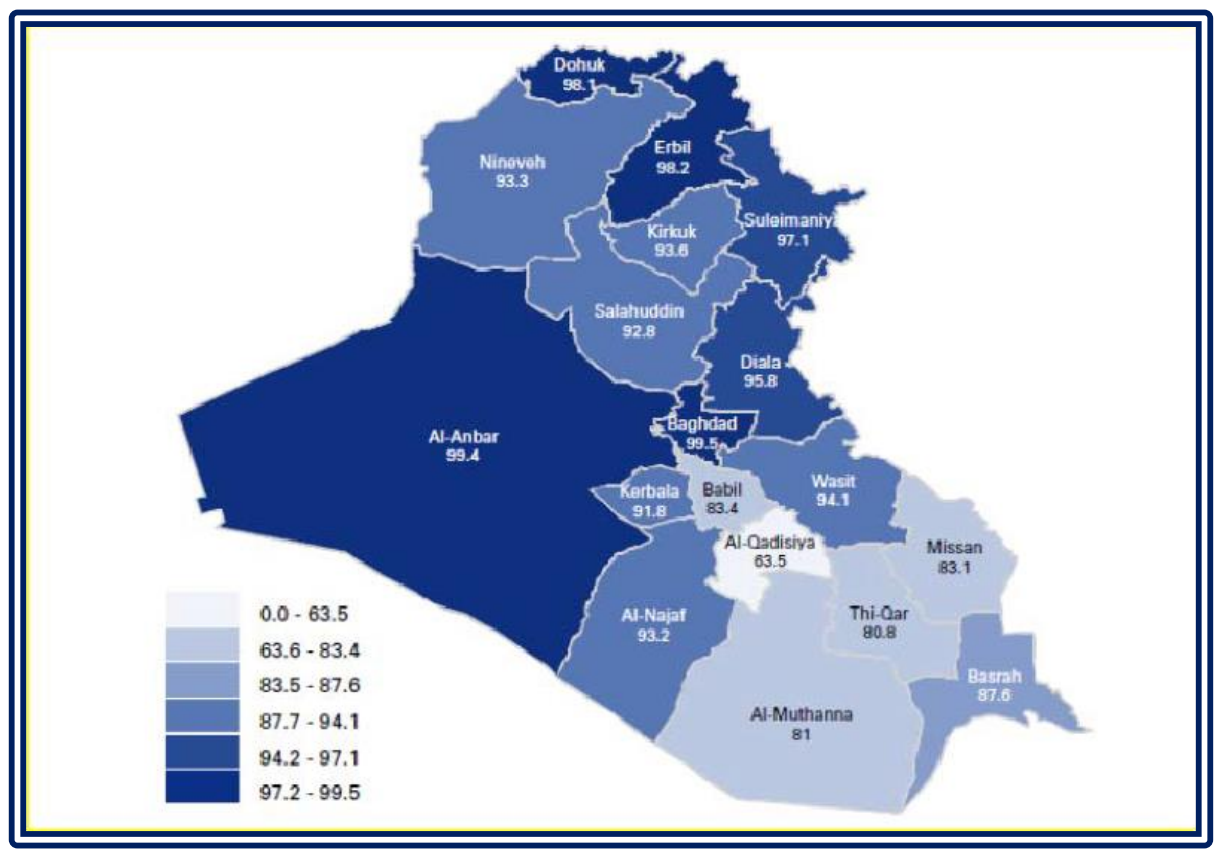

Figure 15: Percentage of household using sanitary means of excreta disposal, by governorate, Iraq, 2005 (source: MICS, 2006). 
According to CHSE (2010) survey conducted in 2005, the sanitation system serves $25.7 \%$ of the population only, $51.2 \%$ of the population using septic tanks and $23.1 \%$ they lack services. The survey also showed that there are 14 and 24 central and small waste-water treatment plants respectively (WWTP). About 31.6\% of the WWTP were operating and $31.6 \%$ were partially operating while the remainder $36.8 \%$ was not working. The designed capacity of these plants is $1,038,018 \mathrm{~m}^{3} /$ day $(97.1 \%$ central WWTP) and the actual capacities were $317,449 \mathrm{~m}^{3} /$ day $(99.5 \%$ central WWTP). The number of heavy WWTP is 194 and the number of pumping station totals to 369 . The length of the pipes connected to these plants is $84,529.413 \mathrm{~km}$, while the number of main holes is 57,610.

Furthermore, it was noticed that $75 \%$ of these plants suffers from flooding in certain areas. It was also stated that these plants and the connected piping system are very old (about 20 years) and for this reason there are large leaks and damages within the system. These projects serve only $26 \%$ of the population up to 2009 . The main obstacles facing this sector are:

1. Low allocated budget.

2. Long age of the system.

3. Lateral expansion of housing.

4. Lack of equipment.

5. Lack of labor.

6. Electricity cuts.

7. The delay in the arrival of mechanical and electrical equipment and pipes.

8. Lack of fuel.

9. Stealing the main holes covers.

10. The use of main holes to put explosive materials and for this reason some were destructed by the government after detecting the presence of the explosive.

11. Delay in the acquisition of the project sites.

12. Inaccuracy designs of some WWTP.

13. The lack of an integrated study of the projects.

14. Adoption of traditional methods and designs for WWTP without any updating.

The number of staff working in these sectors reaches 7,366 of which 506, 1473, 1116 and 4269 are engineers, technicians, administrative and labors (14\% females). The allocated budget for all the governorates excluding Baghdad are listed in Table 8. 
Table 8: Budget allocation for the sanitary sector in Iraq excluding Baghdad in Iraqi Dinars ID.

\begin{tabular}{|l|c|c|c|c|}
\hline Year & $\begin{array}{c}\text { Number of } \\
\text { projects }\end{array}$ & Annual allocation & Expenditure & $\begin{array}{c}\text { \% disbursed from } \\
\text { allocated }\end{array}$ \\
\hline 2004 & 92 & 54,750 & 38,024 & 69.5 \\
\hline 2005 & 14 & 690,650 & 44,385 & 64.3 \\
\hline 2006 & 16 & 56,000 & 18,226 & 32.6 \\
\hline 2007 & 15 & 133,000 & 133,000 & 100 \\
\hline 2008 & 27 & 440,267 & 440,267 & 100 \\
\hline Total & $\mathbf{1 6 4}$ & $\mathbf{7 5 3 0 8 3}$ & $\mathbf{6 7 3 , 9 0 2}$ & $\mathbf{8 9 . 5}$ \\
\hline
\end{tabular}

The suggested projects to be implemented are 48 and the estimated cost is 3,705,000,000 US Dollars. In addition, 10 projects are to be implemented in Baghdad. It was suggested that the requirements (apart from the budget) to implement these projects are:

1. Improving the environmental conditions and reducing pollution through expanding the capacity of WWTP that matches the population growth rate in the cities.

2. Conducting preliminary studies and evaluating consultancy studies of the WWTP and its pipes network including rainwater collection systems.

3. Continuous analysis of samples in the labs.

4. Establishing new units to use the gases generated from WWTP to generate electricity and establishing fertilizers factories to use the solid waste generated from WWTP.

5. Rehabilitation of old systems using new technologies and increasing the capacity of WWTP.

6. Maintenance and cleaning the pipes of old systems.

7. Using the treated waste-water for agricultural purposes.

\subsection{Water Quality}

Water quality of the Tigris and Euphrates is poor due to the return flows from irrigation projects. Inside Iraq, most of the irrigation returns flow is directed to the third drain river which drains to the Gulf. Some of the Tigris flood flows are diverted to Tharthar Lake which is highly saline, and then it is redirected for use in the river system with the salt washed from the lake. The expansion of irrigation in Turkey and Syria will cause a further deterioration in the water quality. In addition, direct discharge of raw sewage into the rivers and industrial effluents are causing more damage (UNICEF, 2003). It was also noticed that over 500,000 cubic meters of raw sewage are discharged into rivers each day, and the rapid increase in water salinity poses an urgent challenge.

TDS values of the Tigris water at the Turkish Iraqi border is $280-275 \mathrm{mg} / \mathrm{l}$ and it reaches more than $1800 \mathrm{mg} / \mathrm{l}$ in Basra (IMMPW, 2011). The TDS of Euphrates 
water at the Iraqi-Syrian border is $600 \mathrm{mg} / \mathrm{l}$ and increases to more than $1,300 \mathrm{mg} / \mathrm{l}$ downstream at Samawa (IMMPW, 2011, World Bank, 2006). The situation might be worse on the tributaries where TDS values in the Diyala River reaches 3,705 $\mathrm{mg} / \mathrm{l}$ (Jawaheri and Alsahmari, 2009).

The quality of drinking water does not meet WHO standards or Iraqi national water quality standards (IAU, 2011). Leakage, in both drinking water distribution and sewerage systems causes high contamination. In view of this situation large number of the population are suffering from various diseases (UN, 2010; A Climate for Change, 2012; MICS, 2007).

\subsection{Desertification}

Declining water flow of the Tigris and Euphrates Rivers, the repeated frequency of drought (Ali et.al, 2013), water quality degradation and increasing soil salinity mean that large areas of Iraq are facing serious problems of desertification. It is believed that at least $45 \%$ of the area of Iraq has been substantially affected by desertification (Raphaeli, 2009). In addition, during the Gulf wars, huge number of palm trees were destroyed which originally were acting as natural barriers against the expansion of desertification. In view of the above, a large number of farmers and fishermen left their land and villages were deserted. The expansion of desert areas led to frequent sand or dust storms. Between 2007 and 2009, 40\% of cropland area experienced reduced crop coverage and 20,000 rural inhabitants left their homes, Figure 16 (IAU, 2011). 


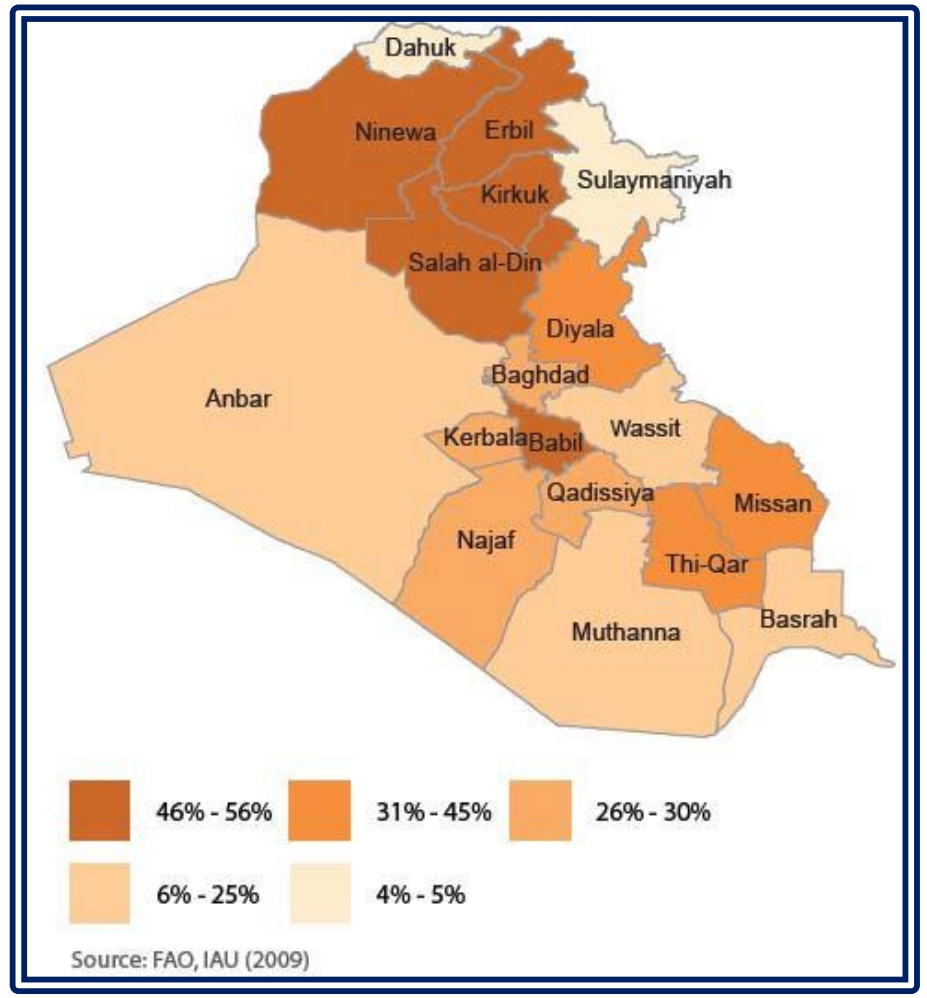

Figure 16: Affected cropland/percentage of cropland (source: IAU, 2011).

Iraq experienced salinity 3800 years ago (The Encyclopedia of Earth, 2008). In 1970 about $50 \%$ of the areas in central and south Iraq were degraded due to waterlogging and salinity. This forced the government to undertake a land rehabilitation program and a total of 700,000 ha were reclaimed. Later the situation deteriorated where recent estimates indicate that $4 \%$ of irrigated areas are severely saline, $50 \%$ are of medium salinity and $20 \%$ are slightly saline (The Encyclopedia of Earth, 2008).

\subsection{Marshes}

The Iraqi marsh lands, which are known as the Garden of Eden, cover an area about $15,000-20,000$ sq. $\mathrm{km}$ in the lower part of the Mesopotamian basin where the Tigris and Euphrates Rivers flow (Figure 17). The marshes lie on a gently sloping plan which causes the two rivers to meander and split into branches forming the marshes and lakes. The marshes had developed after a series of transgressions and regressions of the Gulf sea water. The marshes lie on the thick fluvial sediments carried by the rivers in the area (Al-Ansari, et.al, 2012).

The area has played a prominent part in the history of mankind and was inhabited since the dawn of civilization by the Sumerians who occupied the area before 6000 BP. The area was considered among the largest wetlands in the world and the greatest in western Asia where it supports a diverse range of flora and fauna and 
human populations of more than 500,000 persons and is a major stopping point for migratory birds (Al-Ansari, et.al, 2012; UN, 2010). It has been estimated that $60 \%$ of the fish consumed in Iraq comes from the marshes. In addition, oil reserves have been discovered in and near the marshlands.

The Saddam regime began to drain the marsh lands so that troops could be moved into that area and use the water to block the advances of Iranian troops and perhaps to get rid of the marsh dwellers due to the fact they participated in reprisals against him in 1991(Al-Ansari, et.al, 2012; A Climate for Change, 2012). To enable the army to move inside the marshes, the central government started to execute five major drainage projects to prevent water from the Tigris and Euphrates Rivers from reaching the marshes. Later, the army launched a major attack against marsh dwellers using artillery, mortar and ground attacks. The area was highly contaminated by army munitions and poison gas (Al- Ansari, et.al, 2012).

Accordingly, two third of the marshes were not receiving water inputs in 1993 and by 2000 less than 10\% remained (Figure 17). The consequences were that most of the marsh dwellers left their homes and some animals and plants are extinct now. The government at that time, to change the entire environment of the marshlands, implemented many agricultural projects in the dried areas of the marshlands. The total areas invested in these projects are $1920 \mathrm{~km}^{2}$ distributed over three governorates which are Thi-Qar, Maissan and Basrah (Al-Ansari, et.al, 2012).

After the fall of the Saddam regime in 2003, the Iraqi government, with the help of other countries and international organizations, started the process of restoration and rehabilitation of the Iraqi marshes. There are number of difficulties encountered in the process such as land use changes, climatic variations and changes in soil and water salinity as well as ecological fragmentation where many species were affected as well as the marsh dwellers themselves.

It is believed that $70-75 \%$ of the original areas of the marshes can be restored (AlAnsari, et.al, 2012). The exact areas are 1800, 1800 and $2425 \mathrm{~km}^{2}$ for Al Hammar, Al Hawiza and the Central marshes. This implies that 12,886 MCM water should be available to achieve this goal keeping the water quality as it is (Al-Ansari, et.al, 2012). If the water quality can be improved then $18863 \mathrm{MCM}$ of water is required. The World Bank (2006) estimated that 10-16 BCM/year is required to restore the marshes. This requires plenty of effort and international cooperation to overcome the existing obstacles. 


\section{How to Resolve the Conflict?}

There are differences in the economy, political and military situations of the riparian countries within the Tigris and Euphrates basins. Recently, Syria has been relatively the weakest countries within the basins due to the ongoing war and security situation. The next weakest country is Iraq. This is due to the outcome of the two Gulf wars and the ongoing war on terrorism. Both countries also are the lowest riparian countries within the Tigris and Euphrates basins. For this reason, Iraq will be the most affected country relative to others. In case the situation remains as it is, all future predictions suggest that all riparian countries will be under water shortage stress (Maddocks et al., 2015). Therefore, quick measures are to be taken to overcome the tension and to resolve any conflict between the riparian countries.

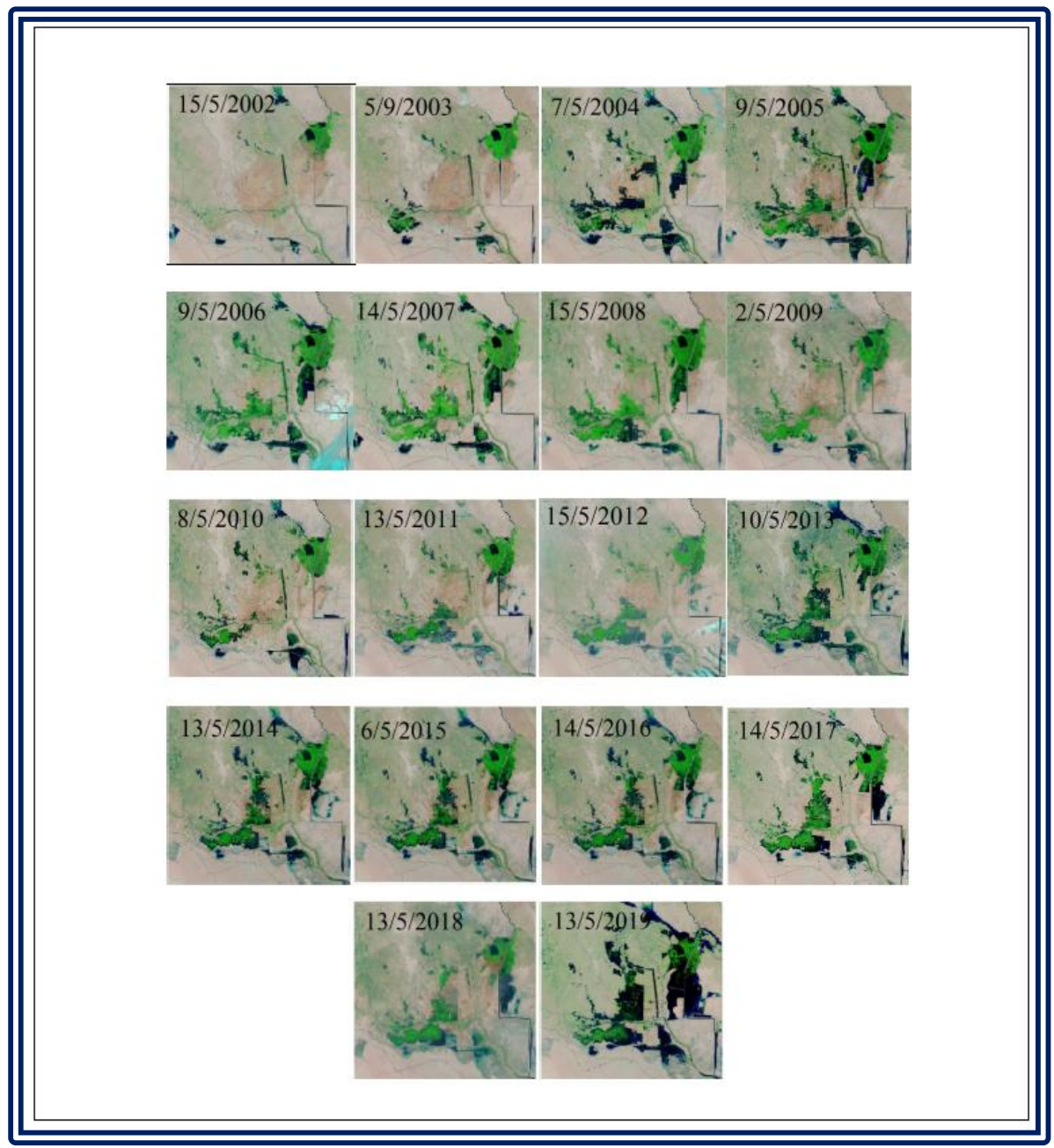

Figure 17: Changes of the area covered by the marshes for the period 2002 to 2019 according to the availability of water. 
Bilateral talks and / or agreements dominated past efforts to resolve the conflict on water rights, which are not sufficient to begin discussions for a regional solution. Negotiations and discussion about water rights were going on with Turkey for more than 30 years and no agreement was signed. As far as Iran is concerned, the first Gulf war was about the water rights within Shat Al-Arab. The discussions and negotiations with both countries should be concerning different matters. It should include security and military, economic, trade, tourism and water issues. If this is not considered, there will be no incentives for Turkey and Iran to discuss the water problem seriously.

Therefore, such negotiations and discussions require a third party to intervene to bring all riparian countries together because they failed to initiate successful triplicate negotiations. Since water issues usually are being eclipsed by more politically charged concerns; then, it is very important to use additional incentives to bring all the parties together (Akanda et al, 2007).

Since Turkey is the riparian hegemon, it should be enticed to negotiate. Two main issues seem to attract the Turkish Government. Finishing the GAP project is the first. This can be done through possible funding agencies like the World Bank or European Union. To do so, Turkey will be asked to sign agreements with downstream riparian counties before releasing any fund. In addition, Iraq is importing plenty of things from Turkey and there are number of Turkish companies working in Iraq. It is noteworthy to mention that Turkey is very worried from Kurdish rebels located in Iraq. Taking this in consideration, then Turkey will seriously act to reach an agreement with Iraq.

The enticement factors for both Iraq and Syria are development assistance, by financial and technical support and increased water efficiency, which will help in developing their agricultural plans, including more innovative advanced projects. As far as joining the European Union which requires improving the human right issue which can be done by involving the Kurds in a cooperative water utilization effort (Akanda et al, 2007). To reach a final solution and sign an agreement between riparian countries this requires an external mediator that can highlight and frame the issues in such a way that each country believes that it is gaining by joining the discussion and will lose something by avoiding the discussions.

To achieve this goal, possible mediators can be:

- World Bank: The World Bank has very good technical expertise that can ameliorate the inefficient, water wasting practices of the countries involved. The World Bank can also attract riparian countries by using its financial incentives to reach a resolution so that it can provide loans to these countries. Finally, The World Bank has very good reputation as a mediator in water issues disputes.

- USA and EU: USA and EU possess political, technical, economic powers as well as being international powerful forces and this can be very useful as mediators. All riparian countries would like to get technical and financial support as well as expertise from USA and EU. In addition, Turkey is connected by different treaties with USA (e.g. NATO). As far as EU is concerned, Turkey is trying to be a member within the EU and is also connected with defense agreements. 
- United Nation: The United Nation has all the required information about the needs and requirements of all riparian countries through its agencies like UNDP, UNEP and FAO. Such information will help in discussions. UN acted as a mediator in different occasions all over the World. Finally, it can use the Security Council if required to enforce agreements.

All the above can be applied to Iraq and Iran as well. In addition to the above, Iraq should set prudent scientific strategic plan to conserve its water resources. AlAnsari (2016) set the outlines of such a plan as follow:

\section{A. Strategic Water Management Vision}

- All official concerned sectors must contribute to planning and designing the "Integrated National Water Master Plan" over long term. The outcomes of this plan should be revealed by the work of the Ministry of Water Resources, Ministry of Municipality and Public Work, Ministry of Agriculture, Water Resources, staff at Universities, private sector, NGO's and representatives of regional and International organizations concerned.

- The hydro infrastructure such as pumping stations, water treatment and hydro power plants should be subjected to a full rehabilitation.

- Encourage the most social sectors to enroll in awareness programs because it is a vital factor to make people to appreciate the seriousness of water issue. In addition, training program for farmers about utilization of new suitable irrigation techniques.

- Defining institutional agenda, including employment and training.

- Supply and demand should be taken into consideration. In this context, seeking for alternative water resources (water harvesting and treated wastewater) beside the conventional methods.

- Promote the private sector to be qualified as an investor in the water sector.

- The coordination between the ministries is quite significant. This will reduce the efforts and save time and money. More decentralization, including budget in irrigation, water supply and sanitation sectors are to be practiced.

- The use of non-conventional water resources for agricultural purposes is of prime importance.

\section{B. Regional cooperation and coordination}

- Determine the technical and institutional requirements to build a solid cooperation.

- Collaboration for smooth exchange for transboundary resources. Exert possible efforts for the riparian countries (Turkey, Syria, Iraq and Iran) to attain a reasonable agreement on water quotas.

- United Nation organizations such as UNEP, UNDP, UNESCO, etc., and the International organizations like FAO, WMO, etc. and other research institutions should be requested to share their capabilities in finding solutions for this issue.

- Build communication network with other bodies which they have a good background in water management to get advices in water issues. Specifically, the 
institutions, organizations and companies in developed countries.

\section{Irrigation and Agriculture}

- The conventional irrigation techniques should be abandoned in order to stop to waste the water. On the other hands, adapted new irrigation techniques, which they are more compatible for the local conditions of soil, water availability and quality, crops ... etc. Apply more efficient methods such as drip irrigation for orchards by using salty water and sprinkler irrigation for grains, and both of them are more conserving than surface irrigation.

- Shifting the conveying system from open channels to closed conduits to increase efficiency of the conveying and minimize the losses. Many advantages could be obtained from closed conduits such as decrease the evaporation and infiltration losses and preventing the direct contact with a saline water table.

- Minimize the soil salinity through improve drainage systems of cultivated lands that will provide better soil leaching. Also, installation a new drainage technique provides an effective solution like use the perforated pipe drainage system in collecting and treating drainage water. Avoiding releases of drainage water to the rivers directly. The path of drainage water should be designed to discharge into the main outfall drain in the areas lying outside the service zone of this drainage project.

- The utilization of chemical fertilizers and pesticides should be reduced. The overuse of these materials can cause the deterioration of water quality when the irrigation water release again into the rivers.

- Install modern treatment methods for drainage and sewage water, and reuse it in restoring water bodies, for instance, the marshes.

- Institutions should reflect decentralization, autonomy and farmer empowerment.

- Encourage the investors to take a part in the agricultural sector.

- $\quad$ Set up awareness program to promote the farmers`awareness regards using the suitable techniques in irrigation (drip irrigation and sprinkler irrigation).

\section{Water Supply and Sanitation}

- Improving the efficiency of drinking water distribution networks specially diversion and supply down to the point of use, which is most cost effective.

- Regular maintenance for the pipes of sewerage networks to prevent any leakages that might occur and lead to pollute the surrounding environment.

- Implement new efficient projects to reduce water losses and protect the environment from pollution.

- Improving services, e.g. using Information communication Technology (ICT).

- Expand the sewage network to cover the areas that not serviced with sewage collection services and connect the newly installed sewage networks to the wastewater treatment plants to avoid the pollution of groundwater from the leakage from old septic tanks.

- Install new sewage treatment plants to satisfy the increased consumption of the domestic sector. Membrane bioreactor technology can be used in these new 
treatment plants to reuse the treated water.

\section{E. Research and Development}

- Prepare and provide the required information for researchers and decision makers by establishing a comprehensive data base which includes reliable climatological, hydrological, geological, environmental and soil data.

- Motivate the researchers to conduct research on developing and creating new technologies in water resources and agriculture which more suitable for Iraqi environment.

- Administrate new methods to satisfy our needs from water and stop our depending on conventional methods. We believe that water harvesting techniques can be very effective and are relative cheap cost wise.

- Raise the level of technicians, engineers and decision makers for understanding the recent utilized technologies through carrying out sessions and training programs.

- Execute pioneer projects, which increase the quantity of water resources, development and productivity, reducing water consumption.

- Placing the structures and outlines of the public awareness programs in terms of water utilization and agricultural activities.

- Asking the universities and institutes to develop their syllabuses to insert special courses in arid region hydrology.

- Awarding of prizes for innovations, pioneer research and smart ideas in water resources and their management.

- Exert more efforts to utilize from the groundwater. This source still not exhausted. Therefore, it should be administered wisely and keep it away from the potential contaminant.

\section{F. Other Techniques that can be used}

There are number of techniques that can be used to save water. These are:

\section{F-1. Climate control with Water Recycling in Greenhouses}

Freshwater is a declining resource in a large part of the world: in the Gulf countries over $90 \%$ of the freshwater consumption is supplied by seawater desalination plants powered by fossil fuel. In arid countries lacking oil reserves, freshwater is imported at great expense (El-Kady and El-Shibini, 2001).

The agricultural sector is by far the largest consumer of freshwater and in very dry climates as much as $95 \%$ of the available freshwater is used for irrigation (Kuylenstierna et.al.,2009). Even though irrigation is vital for sustaining food production in these regions, traditional irrigation techniques on open fields are generally associated with high water consumption and low, and often insecure, crop yield (FAO, 2013). Introducing more water efficient irrigation techniques is therefore a necessary step to expand food production or liberate freshwater to other sectors.

Greenhouse cultivation is water efficient and enables the farmers to produce highvalue crop, even outside growing season (Sharan et.al., 2005). Although 
greenhouses are generally associated with cultivation in cold climates, they may also be used for cultivation protection in warm hot arid regions, using appropriate air-cooling systems.

The greenhouse concept presented here is a novel system for irrigation water re-use and air cooling, which provides a low-cost, low-tech water efficient solution for year-round cultivation of high-value crops is semi-arid to arid countries.

\subsection{System Outline}

The greenhouse climate becomes very hot and humid, even during days with little sunshine. To protect the plants, commercial greenhouses are equipped with ventilation windows integrated in the roof construction (FAO, 2013), or even air conditioners.

In a greenhouse with a sealed bottom, the applied irrigation water will mainly evaporate from the soil or transpire from the plant leaves in the process known as evapotranspiration. Less than $1 \%$ is accumulated in plants as biomass increase.

The vapour formed by the evapotranspiration mixes with the air inside the greenhouse, and as the air is released through the ventilation windows, the irrigated water is lost from the greenhouse as well.

In the system proposed here, the hot and humid air is not primarily vented to the ambient but led into an external pipe system buried in the ground outside the greenhouse. As the air is cooled while flowing through the pipes, vapour precipitates as freshwater. The formed water runs downward along the pipe, and into a subsurface water storage, from where it is pumped back into the greenhouse and used for irrigation. The cooled air is returned from the pipes to the greenhouse (Lindblom, 2012); see Figure 18. 


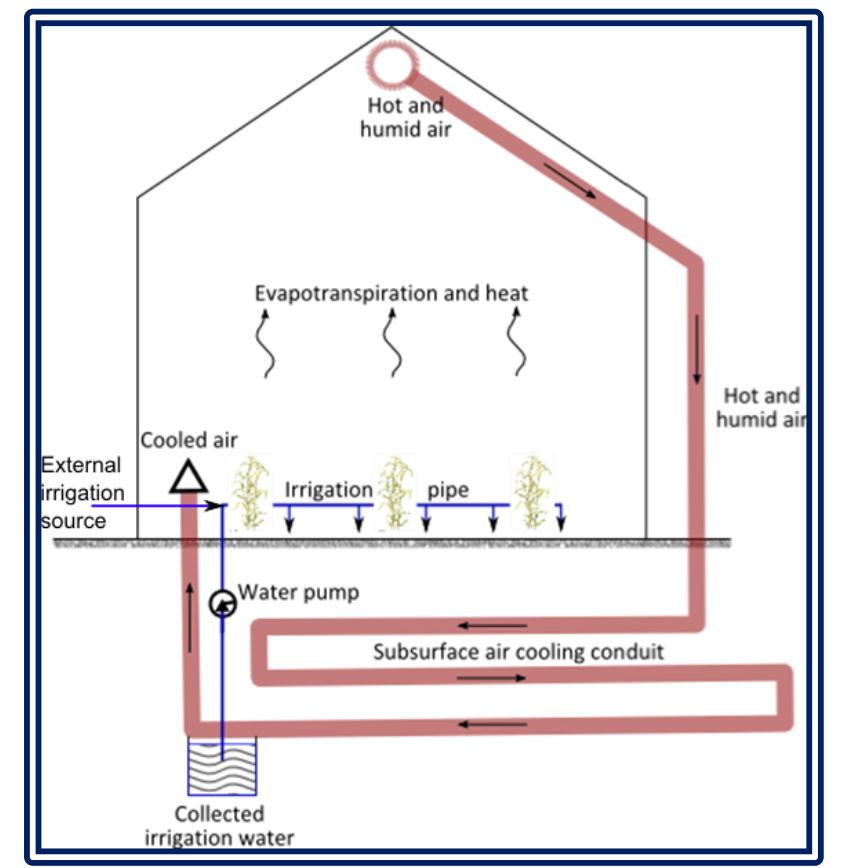

Figure 18: System outline of the water reuse irrigation system.

Hot and humid air is taken from the top of the greenhouse, through a cooler subsurface conduit, and back into the greenhouse. The vapour condensed inside the conduit is collected and used for irrigation.

As an example, consider a greenhouse with dimensions $\mathrm{W} * \mathrm{~L} * \mathrm{H}=10 \mathrm{~m} * 50 \mathrm{~m} * 4 \mathrm{~m}$. During the day, the air close to the ceiling becomes $50^{\circ} \mathrm{C}$ and is fully saturated with water vapour. A regular greenhouse ventilates at least 2 volumes per hour. In the greenhouse with above dimensions, that means that a total air flux of $4,000 \mathrm{~m}^{3} / \mathrm{h}$, containing a total freshwater flux of $344 \mathrm{l} / \mathrm{h}$, is ventilated.

Instead of ventilating the hot and humid air, some of the freshwater can be recycled using the cooled ground and groundwater. By cooling the air flux in the ground from $50^{\circ} \mathrm{C}$ and $100 \% \mathrm{RH}$ to $30^{\circ} \mathrm{C}$ and $100 \% \mathrm{RH}, 235$ litres/hour of freshwater condenses and can be collected, corresponding to $68 \%$ of the total ventilation loss. The irrigation water requirement is thereby reduced to $32 \%$ of the total irrigation requirement of the greenhouse crops.

\subsection{Future Work}

The main challenge in designing this system concerns finding a suitable material and outline for the underground air cooling and dehumidification system. Different solutions for the above will be brought forward, analysed, and compared in future studies, involving investigations of outline of pipes and storages, methods for nighttime ground cooling, and materials used for air flow conduit, e.g. gravel filled pipes, possibilities for groundwater extraction for underground air cooling, etc. 
To finalize the construction details of the pilot greenhouse facility a theoretical model of the most suitable design will be developed that includes mass and energy balances in both the greenhouse and underground cooling system.

A pilot greenhouse will be constructed in accordance with results from the theoretical study. The focus should initially be on providing data for validating the simulation model and assessing the accuracy of the measurements. To facilitate the theoretical simulations, this study should exclude crops in the greenhouse (Chaibi, 2003 and 2011). The soil must nevertheless be irrigated, so that evaporation rates are kept high. Further testing after validation will involve cultivation of selected plants and optimization of the system.

\section{F.2. Rainwater Harvesting Technique to Overcome Water Shortage Introduction.}

The main source of irrigation water in Iraq are the Tigris and Euphrates Rivers, in addition to their main tributaries. The headwaters of these rivers are from Turkey and Syria. The construction of different water storage structures on theses main rivers and tributaries, especially GAP project in Turkey, has caused water shortages in Iraq. That affected the irrigated and planted area in Iraq, causing a significant reduction in agricultural product. That leads to water reaching to critical levels.

The nature and topographies of north part of Iraq and the significant annual rainfall depth, which varies from 735 to 350 (Awchi and Jasim, 2017), enable to study and evaluate the possibility and yields of rainwater harvesting technique. This technique can reduce the shortages' effects. Figure 19, (Awchi and Jasim 2017), shows the average annual rainfall depth for different regions of Iraq for the period 1977-2010. 


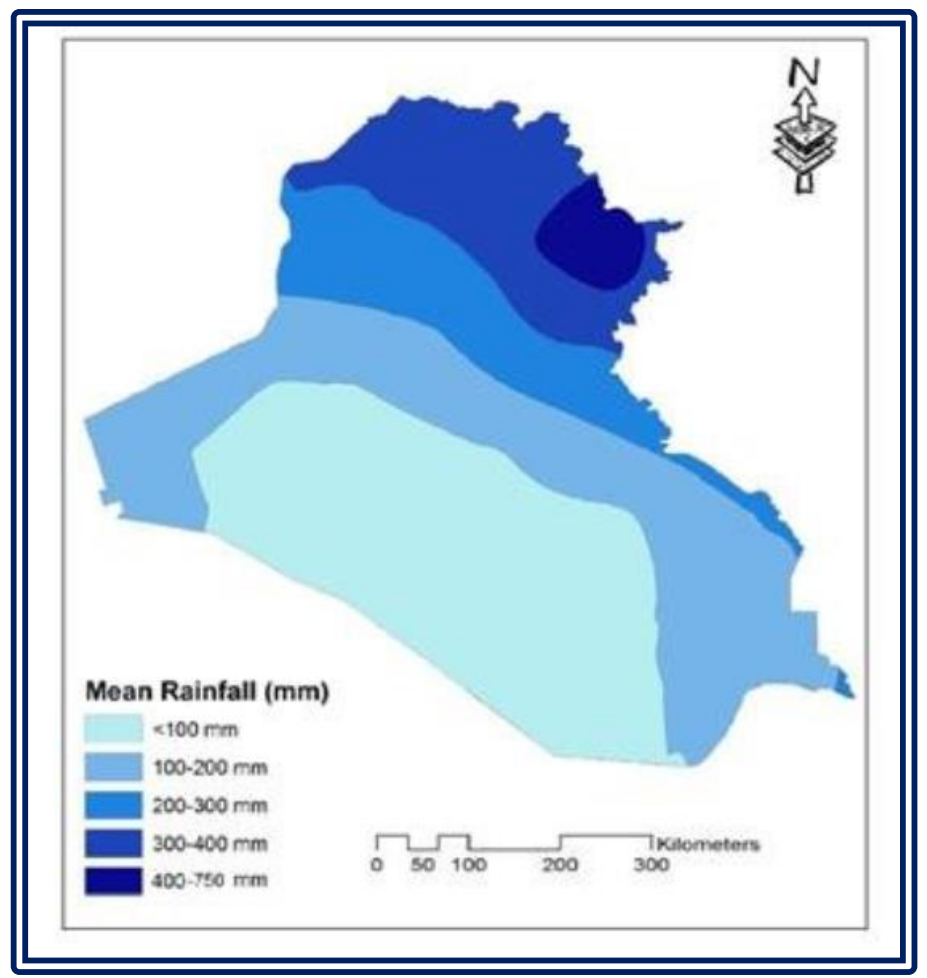

\section{Figure 19: Spatial distribution of annual rainfall in Iraq for the period 1970-2010 (Awchi and Jasim, 2017).}

Although the rainfall depth in this region (northern Iraq) is relatively significant, but it is only distributed through the wet season from October to May, while the other period of the year is dry and no rainfall depth. During the dry period, the main sources of irrigation water are Tigris and Euphrates Rivers. Furthermore, during the wet season, some plants like wheat and barley depend on rainfall as a source of irrigation water, but the non-uniform distribution of the rainfall and the long periods between the storms might affect the plant yields efficiency. Therefore, a supplementary irrigation water is essential to obtain optimal yields. Water harvesting technique can be considered as an efficient tool to store runoff water yields from heavy rainstorm with high intensity, to use later during stopping rain period in wet season and also during dry season.

The idea of water harvesting technique is to collect the rainwater as a runoff from a part of land and to use it later in another part (Owies et al., 2012) for different purposes. Also, this technique can ensure a good plant production on areas having low rainfall depth, less than the required amount to fulfil the plant demand. As an example of this case, for a region having annual rain depth of $150 \mathrm{~mm}$, which is not enough to satisfy plant demand, but if water was harvested from half of the catchment to irrigate the other half, then the rainfall depth will be $300 \mathrm{~mm}$, that satisfies the plant demands (Owies et al., 2012). 


\section{Classification of rain-water harvesting systems}

The runoff water harvesting systems can be classified in to two main types based on the size of the catchments (Oweis et al., 2001):

1. Micro catchment runoff water harvesting.

In this type of water harvesting technique, the runoff water is collected from small catchment, usually less than $1000 \mathrm{~m}^{2}$, and stored in the root zone soil profile. Then the stored water will be used directly by the plants and different crops.

2. Macro catchment runoff water harvesting.

This type is collect water from medium to large catchments, the mountain areas and large basins are considered as the source areas. Water flows through the stream or wadi, then stored in surface or subsurface storages to be used later for different purposes.

In general, all water harvesting systems consist of the following parts (Owies et al. , 2012):

A. Runoff Area: This area represents a part of the catchment which is considered to collect the rainfall-runoff water then use it to irrigate the rest part of the area.

B. Storage Space: A reservoir, pound or tank, which is used to store harvested water, to be used later to satisfy the system purpose/s.

C. Aim: This is represents the user of the harvested water, for agricultural use is the crops, while for domestic, the users may be people or animals.

The oldest water harvesting system might have been built 9,000 years ago on Edom Mountains in southern Jordan (Prinz, 1996), the purpose of that structure is to supply drinking water for people and animals in that region. In Ur city, in Iraq, a water harvesting system had been built about 6,500 years ago (Owies et al., 2012), The system aim was to supply water for domestic and agricultural use.

\section{Studies of water harvesting in Iraq.}

Different previous studies had been presented for rainwater harvesting technique in Iraq. Rahi and Abudi (2005) presented a study to evaluate the potential of rainwater that can be harvested and distributed later in different regions of Iraq. Different techniques had been presented and evaluated.

Hachum and Mohammad (2007) applied the Linear Optimization Technique to determine the optimal reservoir sizing of rain-water harvesting technique for the purpose of supplementary irrigation. The study was applied on an area that had an average annual rainfall depth of $150 \mathrm{~mm}$. The results indicated that the harvesting area should be about three quarters of the total area, and the reservoir storage volume should about $110 \mathrm{~m}^{3} /$ ha of the considered area.

Zakaria et al. 2012, propose a macro rain-water harvesting (large catchment area), to be applied at East Sinjar Mountain in Iraq. They applied Watershed Modeling System (WMS) for four selected basins. The results indicated that the water yields can be used for supplementary irrigation in the studied areas.

Zakaria et al. 2013 applied the macro rain-water harvesting technique in the Kurdistan region in northern Iraq. Both the soil conservation method (SCS-CN) and Watershed Modelling System (WMS) were applied to assess runoff volume at 
Sulaymaniyah province area for the period 2002-2012. The results indicated that the annual harvested water could reach to about $10.8 \mathrm{MCM}$.

Hameed, H, (2013) presented a study to find the suitable zone for rain-water harvesting in Erbil province in northern Iraq. He used Geographical Information System (GIS) and Multi Criteria Evaluation (MCE) as a decision support tool. About $36 \%$ of the studied area indicated a suitability for water harvesting, while $14 \%$ has moderate suitability and $33 \%$ very low suitability. Results showed that macro catchment is the suitable technique for the studied area.

Al-Ansari et al., (2013) applied Watershed Modelling System (WMS) and Linear Optimization (LP) technique to maximize the irrigated area, which could be supplied by supplementary irrigation water from selected runoff water storage reservoirs in Sinjar area northern Iraq. The proposed model was efficient for large scale studied of rainwater harvesting technique with different parameters and constraints. The model was operated for two cases of operation, each reservoir works separately and the connected reservoirs (located on same valley) work as series.

Alwan et al., (2019) applied Soil and Water Assessment Tool (SWAT) model to estimate the runoff volume and feasibility of construction water harvesting dams in $\mathrm{Al}$ Anbar province (western part of Iraq) for agricultural purposes. The studied area has a catchment ranging between $120 \mathrm{~km}^{2}$ to $675 \mathrm{~km}^{2}$. The results indicated that the total annual runoff yield could be store in proposed dams is about 13MCM.

Abdullah et al. (2020) presented a study to evaluate the water harvesting technique in Western Desert, Jazeera Desert and Eastern Valleys in Iraq. The results indicated that the water yields were significant on the studied zones and that water harvesting could be employed effectively.

Most of the previous studies are based on theoretical analysis and evaluation of water harvesting systems. Field work and more detailed assessments should be researched to ensure the feasibility of application this technique.

Acknowledgment: The author would like to thank Dr Jenny Lindblom and Dr Mohammad Ezz-Aldeen of Lulea University of Technology for supplying some material for this work. Mr Nasrat Adamo gratefully reviewed some of the parts of this work. 


\section{References}

[1] Abbas, N., Al-Ansari, N., Wasimi, S. and Al-Rawabdeh, A.M. (2019). Flow variation of the major tributaries of Tigris River due to climate change. Engineering, 11(8), pp.437-442.

[2] Abbas, N., Wasimi, S.A. and Al-Ansari, N. (2017). Impacts of Climate Change on Water Resources of Greater Zab and Lesser Zab Basins, Iraq, Using Soil and Water Assessment Tool Model. International Journal of Environmental, Chemical, Ecological, Geological and Geophysical Engineering, 11(10), pp.823-829.

[3] Abbas, N., Wasimi, S.A. and Al-Ansari, N. (2020). Impacts of Climate Change on Water Resources of Fitzroy River and Tigris River Basins and Identification of Adaptation Measures. PhD thesis, University of Central Queensland, Australia.

[4] Abbas, N., Wasimi, S.A., Al-Ansari, N. and Nasrin Baby, S. (2018). Recent trends and long-range forecasts of water resources of northeast Iraq and climate change adaptation measures. Water, 10(11), p.1562.

[5] Abbas N., Wasimi S., Al-Ansari N. and Nasrin, S. (2018). Recent trends and long-range forecasts of water resources of northeast Iraq and climate change adaptation measures, J. Water, special issue Water Resources Management Strategy under Globe Change, V. 10 (1562), 2-19. doi:10.3390/w10111562

[6] Addullah, A. A. (2012). Shared Rivers between Iraq and Iran and its effect on Agricultural lands and Food Security, Tikrit University J., 20, 1, pp.356-388.

[7] Abdullah, A. D. (2016). Modelling Approaches to understand Salinity Variation in Highly Dynamic Tidal River. The case of the Shatt Al-Arab River, $\mathrm{PhD}$ thesis, Delft University of Technology and of the Academic Board of the UNESCO-IHE, Delft, the Netherlands.

[8] Abdullah, M., Al-Ansari, N. and Laue, J. (2020). Water Harvesting in Iraq: Status and Opportunities. Journal of Earth Sciences and Geotechnical Engineering, 10, (1), pp.199-217.

[9] Abumoghli, I. (2015). Water Scarcity in the Arab World. EcoME AND NORTH AFRICA, August 2, 2015. http://www.ecoME and North Africa.org/water-arab/ Last accessed August 10, 2016.

[10] Akanda, A., Freeman, S. and Placht, M. (2007). The Tigris-Euphrates River Basin: Mediating a Path Towards Regional Water Stability. Al Nakhlah, the Fletcher School Journal for Issues Related to Southwest Asia and Islamic Civilization, Spring, p. 1-12. http://www.kenn.at/Fresh-

Water/tigris\%20euphrates\%20river\%20basinmediating $\% 20 \mathrm{a} \% 20$ path $\% 20$ towards $\% 20$ regional $\% 20$ water\%20stability.pdf Last accessed January 18, 2018.

[11] Al-Ansari, N. (1998). Water Resources in the Arab countries: problems and possible solutions, UNESCO International Conference on World Water Resources at the Beginning of the 21st Century 3-6 June, Paris, 1998, pp.367376. 
[12] Al-Ansari, N.A. (2016). Hydropolitics of the Tigris and Euphrates Basins, Engineering, 8, 3, pp.140-172.

[13] Al-Ansari, N.A. (2013). Management of Water Resources in Iraq: Perspectives and Prognoses, J. Engineering, V.5, 8, pp.667-68.

[14] Al-Ansari, N. A. and Toma, A. (1985). Suspended Sediment waves in the River Tigris at Sari station for the year 1982, Inter. Symp, on Erosion, Debris flow and Disaster Prevention Keynote, Japan, pp.157-162.

[15] Al-Ansari, N. A. and Ali, J. L. (1986). Suspended load and solute discharge in River Tigris within Baghdad, J. Water Res., V. 5, pp.35-50.

[16] Al-Ansari, N. A., Assad, N., Walling, D. E. and Hussan, S. A. (1988). The suspended sediment discharges of River Euphrates at Haditha, Iraq, Geografisca Annaler, 70 A, 3, pp.203-213.

[17] Al-Ansari, N.A. and Knutsson, S. (2011). Possibilities of restoring the Iraqi Marshes known as the Garden of Eden, Water and Climate Change in the ME AND NORTH AFRICA-Region, International Conference, Germany, 28-29 April, 2011.

[18] Al-Ansari, N.A., Knutsson, S. and Ali, A. (2012). Restoring the Garden of Eden, Iraq. Journal of Earth Sciences and Geotechnical Engineering, Vol.2, No.1, pp.53-88

[19] Al-Ansari, N.A., Abdellatif, M., Zakaria, S., Mustafa, Y. and Knutsson, S. (2014a). Future Prospects for Macro Rainwater Harvesting (RWH) technique in north east Iraq, J. Water Resource and Protection, 6, 5,pp.403-420.

[20] Al-Ansari, N.A., Abdellatif, M., Ezeelden, M., Ali, S. and Knutsson, S. (2014b). Climate Change and Future Long-Term Trends of Rainfall at Northeastern Part of Iraq, J. Civil Engineering and Architecture, 8, 6,pp.790-805.

[21] Al-Ansari, N.A., Knutsson, S. and Almuqdadi, K. (2014c). Engineering solution for Radioactive Waste in IRAQ, J. Advance Science and Engineering Research, V. 4, No.1, pp.18-36.

[22] Al-Ansari, N.A., Abdellatif, M., Ezeelden, M.,Ali, S. and Knutsson, S. (2014d). Climate Change and Future Long-Term Trends of Rainfall at North-East Part of Iraq, J. Civil Engineering and Architecture, V.8, 66,790-805.

[23] Al-Ansari, N.A., Abdellatif, M., Ali, S. and Knutsson, S. (2014e). Long Term Effect of Climate Change on Rainfall in Northwest Iraq, Central European Journal of Engineering, V.4, No.3, pp.250-263.

[24] Al-Ansari, N., Mohammad, E.M., Knutsson, S. and Zakaria, S. (2013). Water Harvesting and Reservoir Optimization in Selected Areas of South Sinjar Mountain, Iraq, Journal of Hydrologic Engineering, ASCE, 18 (12), pp.16071616.

[25] Al Ansary, K. (2015). Wheat-Importing Iraq Plans to Be Net Grain Exporter by 2017. Blooming Business, 10th June, 2015.

http://www.bloomberg.com/news/articles/2015-06-10/iraq-to-become-wheatexporter-within-2-years-trade-ministry Last accessed March 8, 2018.

[26] Ali, A.H. (2018). Water Crisis in Iraq: Challenges and Solutions, Al-Bayan Center for Planning and Studies, Baghdad, Iraq. 
[27] Allan, T. (2001). The ME Water Question, I.B. Tauris Publishers, London.

[28] Alnajaf News Net (2009). The GAP project and its negative implications on Iraq,http://www.alnajafnews.net/najafnews/news.php?action=fullnews\&id=3 1503, Last accessed February 16, 2018.

[29] Al-Shahrabaly, Q. (2008). River Discharges for Tigris and Euphrates Gauging Stations. Ministry of Water Resources, Baghdad (in Arabic).

[30] Alsowdani, M. (2005). GAP project and its economic negative implications on Syria and Iraq. Aletehad News, http://www.alitthad.com/paper.php?name=News\&file=print\&sid=19030 Last accessed June 20, 2016

[31] Altinbilek, D. (2004). Development and Management of the Euphrates-Tigris Basin, Water Resources Development, 20, 1, pp.15-33.

[32] Alyaseri, S. (2009). GAP project: Dangerous consequences on life in Iraq, Official site of Iraqi Council for Peace and Unity, http://www.marafea.org/paper.php?source=akbar\&mlf=copy\&sid=11556

[33] Alwan, K., Ali Al-Kubaisi, M. and Al-Ansari, N. (2019). Validity of Existing Rain-Water Harvesting Dams within Part of Western Desert, Iraq. Engineering, 11, pp.806-818

[34] Awchi, T. and Jasim, A. (2017). Rainfall Data Analysis and Study of Meteorological Draught in Iraq for the Perio.

[35] Aydin, M. and Ereker, F. (2009). Water Scarcity and Political Wrangling: Security in the Euphrates and Tigris Basin, In Brauch et al. eds., Facing Global Environmental Change: Environmental, Human, Energy, Food, Health and Water Security Concepts, Springer, Berlin.

[36] Bagis, A. (1989). GAP, Southeastern Anatolia Project: The Creadle of Civilization Regenerated (Istanbul Interbank, 1989).

[37] Bari, Z. (1997). Syrian -Iraq disputes over the Euphrates waters. International Studies, SAGA Journals, 16,2, pp.227-244.

[38] Barr J., Grego S., Hassan E., Niasse M., Rast W. and Talafré, J. (2012). Regional challenges, global impacts, in Managing Water under Uncertainty and Risk. UN World Water Development Report 4, Chapter 7.

[39] Bazzaz, F. (1993). Global climatic changes and its consequences for water availability in the Arab World, in Roger, R. and Lydon, P. (Ed.), Water in the Arab Word: Perspectives and Prognoses, Harvard University, pp.243-252.

[40] Beaumont, P. (1995). Agricultural and environmental changes in the upper Euphrates catchment of Turkey and Syria and their political and economic implications. Applied Geography, Volume 16, Issue 2, April 1996, pp.137-157.

[41] Berardinucci, J. (2010). The Impact of Power on Water Rights: A Study of the Jordan and Tigris-Euphrates Basins, School of International Service. American University, Washington DC, Bachelor of Art report. http://aladinrc.wrlc.org/bitstream/handle/1961/9171/Berardinucci,\%20Jessica \%20-\%20Spring\%20'10\%20(P).pdf?sequence=1 Last accessed March 14, 2018. 
[42] Beschorner, N. (2008). Water and Instability in the ME. Adelphi Paper 273.Available at: https://www.tandfonline.com/toc/tadl19/32/273.

Last accessed March 14, 2018.

[43] Bilen, O. (2000). Turkey and Water Issues in the ME (2nd edition), Ankara, Republic of Turkey.

[44] Biswas, A.K. (1991). Water for Sustainable Development in the Twenty- First Century: A Global Perspective, GeoJournal 24,4, pp.341-345.

[45] Biswas, A.K. (1993). Management of International Waters: Problems and Perspectives, international Journal of Water Resources Development, 9, 2, pp.167-188.

[46] Biswas, A.K., ed. (1994). International Waters of the ME- From Euphrates, Tigris to Nile. Bombay, India, Oxford.

[47] Bremer N. (2015). Dams on Euphrates and Tigris: Impacts and Regulation through International Law. Justus-Liebig -Unevrsität Gießen. Available at: https://www.researchgate.net/publication/284279506_Dams_on_Euphrates_a nd_Tigris_Impact_and_Regulation_Through_International_Law Lasted accessed March 16, 2018.

[48] Centre for Strategic Research (1996). Water Issues between Turkey, Syria and Iraq. Turkish ministry of foreign affairs, June-August 1996. Available at: http://sam.gov.tr/water-issues-between-turkey-syria-and-iraq.

Last accessed March 18, 2018.

[49] Charrier, B. and Curtin F. (2007). A vital paradigm shift to maintain habitability in the ME: the integrated management of international watercourses. In Water for peace in the ME and Southern Africa. Geneva: Green Cross International, 11-1.

[50] Chenoweth, J. Hadjinicolaou, P., Bruggeman,A., Lelieveld, J., Levin, Z., Lange, M.A., Xoplaki, E. and Hadjikakou, M. (2011). Impact of climate change on the water resources of the eastern Mediterranean and ME region: Modeled 21st century changes and implications, Water Resources Research, Vol. 47, 6, pp.1-18.

[51] Cherfane, C.C. and Kim, S. E. (2012). Arab region and Western Asia, UNESCWA, in Managing Water under Uncertainty and Risk, UN World Water Development Report 4, Chapter 33.

[52] Chaibi, M.T. (2011). Greenhouse with Integrated Solar Desalination for Arid Regions. Lambert Academic Publishing.

[53] Chaibi, M.T. (2003). Greenhouse systems with integrated water desalination for arid areas based on solar energy, $\mathrm{PhD}$ thesis. Swedish University of Agricultural Sciences.

[54] Cockburn, P. (2009). As Iraq runs dry, a plague of snakes is unleashed. The Independent, http://www.independent.co.uk/environment/nature/as-iraq-runsdry-a-plague-of-snakes-is-unleashed-1705315.html Main page, Depletion of the Euphrates flow. http://www .alrroya .com/node/10899. 
[55] CEB (Consulting Engineering Bureau) (2011a). Tigris and Euphrates sampling, Final Report, College of Engineering, University of Baghdad, Iraq.

[56] CEB (Consulting Engineering Bureau) (2011b). Lakes Testing Study, College of Engineering, University of Baghdad, Baghdad.

[57] Charts Bin (2018). Total Renewable Water Resources Dependency Ratio by Country. Available at: http://chartsbin.com/view/1471. Last accessed March 17, 2018.

[58] Drake, C. (2007). Water Resource Conflicts in the ME, J. Geography, 96,1, pp.4-12.

[59] Daoudy, M. (2009). Asymmetric Power: Negotiating Water in the Euphrates and Tigris, J. International Negotiation, 14, pp.359-389.

[60] Dinar Advice Guru (2014). Iraq-Iran Talks on Borders, Shatt al- Arab, Iraqbusiness news, March 4, 2014.

Link: http://www.iraq-businessnews.com/2014/03/04/iraq-iran-talks-onborders-shatt-al-arab/ Last accessed March 19, 2018.

[61] Elhance, A. P. (1999). Hydropolitics in The Third World: Conflict and Cooperation in International River Basins, United States Institute of Peace, Washington DC, USA.

[62] El-Kady, M and El-Shibini, F. (2001). Desalination in Egypt and the future application in supplementary irrigation, Desalination 136(1), pp.63-72.

[63] El Raey, M. (2010). Impact of sea level rise on the Arab Region. University of Alexandria. Arab Academy of Science, Technology and Maritime.

[64] ESCWA (Economic and Social Commission for Western Asia) (2013). Inventory of Shared Water Resources in Western Asia, Salim Dabbous Printing Co., Beirut, Lebanon, 626p.

[65] FAO (Food and Agricultural Organization) (2003). Towards sustainable agricultural development in Iraq: The Transition from Relief, Rehabilitation and Reconstruction to Development. 222 pp. Available at http://www.fao.org/docrep/006/y9870e/y9870e00.htm Last accessed in February, 2018.

[66] Fadel, K., Sayegh, Y., Abou Ibrahim, A., Jamali, D. and El-Fadel, K. (2002). The Euphrates-Tigris Basin: A Case study in Surface Water Conflicts Resolution. J. Natural Resources, Life Science Education, 31, 99-110. https://www.agronomy.org/files/jnrlse/issues/2002/e01-13.pdf

[67] FAO (Food and Agriculture Organization) (2008a). AQUASTAT global water information system, Turkey. Available at: http://www.fao.org/nr/water/aquastat/countries_regions/TUR/

[68] FAO (Food and Agriculture Organization) (2008b). AQUASTAT global water information system, Syria. Available at: http://www.fao.org/nr/water/aquastat/countries_regions/SYR/SYRCP_eng.pdf

[69] FAO (Food and Agriculture Organization) (2008c). AQUASTAT global water information system, Iran. Available at: http://www.fao.org/nr/water/aquastat/countries_regions/IRN/ 
[70] FAO (Food and Agriculture Organization) (2008d). AQUASTAT global water information system, Iraq. Available at: http://www.fao.org/nr/water/aquastat/countries_regions/IRQ/

[71] FAO (Food and Agricultural Organization) (2009a). Turkey, Water Report 34. http://www.fao.org/nr/water/aquastat/countries_regions/TUR/ Last accessed February, 2018.

[72] FAO (Food and Agricultural Organization) (2009b). Syria, Water Report 34. http://www.fao.org/nr/water/aquastat/countries_regions/SYR/ Last accessed February, 2018.

[73] FAO (Food and Agricultural Organization) (2009c). Iraq, Water Report 34. http://www.fao.org/nr/water/aquastat/countries_regions/IRQ/ Last accessed February, 2018.

[74] FAO (2013). Good Agricultural Practices for greenhouse vegetable crops: Principles for Mediterranean climate areas. FAO Plant and Production Paper 217. Food and Agriculture Organization of the United Nations, Rome, 2013. http://www.fao.org/docrep/018/i3284e/i3284e.pdf

[75] GAP (2006). South-eastern Anatolia Project: latest situation, http://www.gap.gov.tr/English/Genel/sdurum.pdf

[76] Gleick, P. (1996). Basic Requirements for Human Activities: Meeting Basic Needs, Water International, 21, pp.83-92.

[77] Gleick, P. (2014). Water, Drought, Climate Change, and Conflict in Syria, Weather, Climate and society J., 6, 3, pp.331 -340

[78] Gruen, G. E. (2000). Turkish Waters: Source of Regional Conflict of Catalyst for Peace?. Water, Air, and Soil Pollution 123, pp.565-579.

[79] Guerin, K. (2003). Property Rights and Environmental Policy: A New Zealand Perspective, New Zealand Treasury Working Paper 03/02, Wellington.

[80] Friedman, T. (2013). Without Water, Revolution, SUNDAYREVIEW, May 18, 2013. http://www.nytimes.com/2013/05/19/opinion/sunday/friedmanwithout-water-revolution.html?_r=0 Last accessed March 9, 2018.

[81] Hachum, Y. A. and Mohammad E. M. (2007). Optimal Reservoir Sizing for Small Scale Water Harvesting System Optimal Reservoir Sizing for Small Scale Water Harvesting System at Al-Hader in Northren Iraq, Al-Rafidain Engineering Journal (AREJ), 15, (3), pp.83-97.

[82] Hamdy, A. (2013). Water Crisis and Food Security in the Arab World: The Future Challenges, accessed in 23 August. http://gwpmed.org/files/IWRMLibya/Atef\%20Hamdy\%20AWC.pdf Last accessed March 11, 2018.

[83] Hameed, M., Ahmadalipour, A., Moradkhani, H. (2018). Apprehensive Drought Characteristics over Iraq: Results of a Multidecadal Spatiotemporal Assessment, J. Geosciences, 8, 58, pp.1-16.

[84] Hameed, H. M. (2013). Water harvesting in Erbil Governorate, Kurdistan region, Iraq Detection of suitable sites using Geographic Information System and Remote Sensing. Master Thesis, Department of Physical Geography and Ecosystems Science Lund University, Sweden. 
[85] Hatfield, J.L. and Prueger, J.H. (2015). Temperature extremes: Effect on plant growth and development. Weather and climate extremes, 10, pp.4-10.

[86] Hillel, D. (1994). Rivers of Eden: The Strungle for Water and the Quest for Peace in the ME. Oxford University Press and Madzini and Wolf, N.Y.

[87] Hillman, A. J., Withers, M. C. and Collins, B. J. (2009). Resource Dependence Theory: A Review, Journal of Management 35, 6, pp.1404-27.

[88] Hiniker, M. (1999). Sustainable Solutions to Water Conflicts in the Jordan Valley. Cambridge Review of International Affairs, 12, 2, pp.255-273.

[89] Harkins, J. and Forster-Holt, N. (2014). Resource Dependence and the Exits of Young Firms, Entrepreneurship Research Journal, 2014, 4, 4, pp.323-349.

[90] ILA, Helsinki (1967). The Helsinki Rules, of the Uses of Waters of International Rivers. Report of the ILA Committee on the use of waters of International Rivers London. Available at: http://www.thehinducentre.com/multimedia/archive/03021/The_Helsinki_Ru les_3021443a.pdf . Last visited March 18, 2018.

[91] IPCC (Intergovernmental Panel on Climate Change) (2007a). Climate change 2007: climate change impacts, adaptation and vulnerability. Cambridge University Press, Geneva.

[92] IPCC (2014). Climate Change 2014 The Physical Science Basis: contribution of Working Group I to the fifth assessment report of the Intergovernmental Panel on Climate Change, Cambridge University Press.

[93] Iraqi Ministry of Water Resources (2015). Climate change analysis in North of Iraq, viewed on 20 April 2015, https://www.developmentaid.org/\#!/donors/view/34731/republic-of-iraqministry-of-water-resources.

[94] Iraqi Ministry of Municipalities and Public Work (IMMPW) (2011). Water Demand and Supply in Iraq: Vision, Approach and Efforts, GD for Water. http://www.mmpw.gov.iq/

[95] Issa, I. E., Al-Ansari, N. Sherwany, G. and Knutsson, S. (2014). Expected Future of Water Resources within Tigris-Euphrates Rivers Basin, Iraq. Journal of Water Resource and Protection, vol. 6, pp.421-432.

[96] Janabi, H. (2013). Climate Change Impact on Iraqi Water and Agriculture Sectors. Viewed 18 December 2014. http://iraqieconomists.net/en/2013/04/05/climate-change-impact-on-iraqiwater-and-agriculture-sectors/>

[97] Jones, M. (1995). Critical factors in transnational river disputes: An analytical framework for understanding the India- Bangladesh water scarcity dispute over the Ganges River, Unpublished Master Thesis. The Miami University at Oxford, Ohio, Department of Geography.

[98] Jones, D. (2009). Iraq reaches water, energy and trade agreements with Turkey, Voice of America on reliefweb 19th September, 2009. https://reliefweb.int/report/iraq/iraq-reaches-water-energy-and-tradeagreements-turkey. Last Accessed March 16, 2018 
[99] Lowi, R.M. (1995). Water and Power: The Politics of a Scarce Resource in the Jordan River basin. Cambridge University Press, Cambridge, UK.

[100] Kamel, A., Sulaiman, S. and Mustaffa, S. (2013). Study of the Effects of Water Level Depression in Euphrates River on the Water Quality, J. Civil Engineering and Architecture, V.7, 2, pp.238-247.

[101] Kamona, H. (2003). The effect of Turkish water policy on Iraq. AlSabah Iraqi news net, 17/05/2003, Baghdad, Iraq.

[102] Keenan, T., and Cleugh, H. (2011). Climate science update: a report to the 2011 Garnaut Review. Centre for Australian Weather and Climate Research, Canberra.

[103] Kibaroglu, A. (2008). The Role of Epistemic Communities in Offering New Cooperation Frameworks in the Euphrates-Tigris Rivers System. J. of International Affairs 61, 2, pp.183-198.

[104] Kibaroglu, A. and Scheumman, W. (2011). Euphrates-Tigris Rivers System: Political Rapprochement and Transboundary Water Cooperation, in A. Kibaroglu et al. (eds.), Turkey's Water Policy, DOI 10.1007/978-3-64219636-2_16, \# Springer-Verlag Berlin Heidelberg.

[105] Kolars, J. (1994). Problems of International River Management: The case of the Euphrates, in Biswas A.(Ed.), International Waters of the ME from Euphrates-Tigris to Nile, Chapter 3, pp.44-94, Water Management Series 2, Oxford University Press, Bombay.

[106] Kuylenstierna, J., Björklund, G. and Najlis, P. (2009). Sustainable water future with global implications: everyone's responsibility, in Natural resources forum, Vol. 21, Wiley Online Library, pp.181-190.

[107] Lindblom, J. (2012). Condensation irrigation - A Combined System for Desalination and Irrigation, $\mathrm{PhD}$ thesis. Luleå University of Technology.

[108] Lough, J. M. and Hobday, A. J. (2011). Observed climate change in Australian marine and freshwater environments. Marine and Freshwater Research, Vol. 62, No.9, pp.984-999.

[109] MacQuarrie, P. (2004). Water Security in the ME, Growing Conflict over Development in the Euphrates-Tigris Basin. M. Phil thesis, Trinity College, Dublin, Ireland.

[110] Maddocks, A., Young, R.S. and Reig, P. (2015). Ranking the World's Most Water-Stressed Countries in 2040, World Resources Institute. Available at:http://www.wri.org/blog/2015/08/ranking-world\%E2\%80\%99s-mostwater-stressed-countries-2040 Last accessed February, 2018.

[111] Majeed, Y. (1993). The central Regions: Problems and Perspectives, in Roger, R. and Lydon, P. (Ed.), Water in the Arab Word: Perspectives and Prognoses, Harvard University, pp.101-120

[112] Martin, L. and Kerids, D. (2003). The Future of Turkish Foreign Policy, Cambridge, Massachusetts. MIT press, 354p.

[113] Medany, M. (2008). Impact of climate change on Arab countries. Journal of Europe, Vol. 22, No. 22, pp. 8. 
[114] Morris, M. E. (1992). Poisoned wells: The politics of water in the ME, ME Insight, 8 , 2, pp.35-39.

[115] Najibi, N. and Devineni, N. (2018). Recent trends in the frequency and duration of global floods. Earth Syst. Dynam., 9, pp.757-783.

[116] Najibi, N., Devineni N., and Lu, M. (2017). Hydroclimate drivers and atmospheric teleconnections of long duration floods: An application to large reservoirs in the Missouri River Basin. Advances in water resources, 100, pp.153-167.

[117] NASA (2009). Drought in Iraq. NASA Earth Observatory. Available at: https://earthobservatory.nasa.gov/NaturalHazards/view.php?id=38914 Last accessed March13, 2018.

[118] National Defense Magazine (2009). Turkish Israeli partnership in GAP Southeastern Anatolian Project, Official site of the Lebanese Army, http://www.lebarmy.gov.lb/ article.asp?ln =ar\&id=2901. Last accessed February 15, 2018.

[119] New York Times (2013). Without Water, Revolution, May 18, 2013. http://www.nytimes.com/2013/05/19/opinion/sunday/friedman-withoutwater-revolution.html?_r=0 Last accessed March 18, 2018.

[120] Oei, P. and Siehlow, M. (2016). Modelling Water Management Optimal for the Tigris-Euphrates River sheds. International Journal of Environmental Science, 1 , 40-150. http://www.iaras.org/iaras/filedownloads/ijes/2016/008-0022.pdf

[121] ONWAR.com. (2017). Iran-Iraq War 1980-1990, ONWAR. Com /conflicts./Link last accessed on 20th March 2018 https://www.onwar.com/aced/chrono/c1900s/yr80/firaniraq1980.htm

[122] Osman, Y., Al-Ansari, N.A. and Abdellatif, M. (2017a). Climate Change Model as a Decision Support Tool for Water Resources Management: A case Study of Greater Zab River. J. Water and Climate Change, 8, 8, pp.1-14.

[123] Osman Y., Abdellatif, M., Al-Ansari, N.A., Knutsson, S. and Aljawad S.B. (2017b). Climate Change and Future Precipitation in Arid Environment of ME: Case study of Iraq, J. Environmental Hydrology, 25, paper 3, pp.1-18.

[124] Oweis, T., Prinz, D. and Hachum, A. (2012). Rainwater harvesting for agriculture in the dry areas, CRC Press/Balkema, Taylor \& Francis Group, London, UK, p.262.

[125] Oweis, T., Prinz, D. and Hachum, A. (2001). Water Harvesting: Indigenous Knowledge for the Future of the Drier Environments, ICARDA, Aleppo, Syria.

[126] Pfeffer, J. (1987). A resource dependence perspective on interorganizational relations, in Mizruchi, M. S. and Schwartz, M., Intercorporate Relations: The Structural Analysis of Business. Cambridge University Press, Cambridge UK, pp.25-55.

[127] Pfeffer, J. and Salancik, G. R. (1978). The external control of organizations: A resource dependence perspective. New York: Harper \& Row. 
[128] Prinz, D. (1994). Water Harvesting and Sustainable Agriculture in Arid and Semi-arid Regions. In: Lacirignola, C. and A. Hamdy (eds). Proceedings, CIHEAM Conference Land and Water Resources Management in the Mediterranean Region 04 - 08. September, 1994, Valencano (Bari), Vol. III, pp.745-762.

[129] Rahi, K. A. and Abudi, Z. N. (2005). Rainwater Harvesting Techniques Applied to Some Iraqi Zones. Journal of Engineering and Development, 9, (2), pp.82-90.

[130] Ravindranath, A., Devineni, N. and Kolesar, P. (2016). An environmental perspective on the water management policies of the Upper Delaware River Basin, Water Policy, 18, 6, pp.1399-1419.

[131] Reed, C. (2005). Paradise Lost? What should--or can--be done about "the environmental crime of the century"? Harvard Magazine, January-February (2005). http://harvardmagazine.com/2005/01/paradise-lost.html Last accessed March 9, 2018.

[132] Reig, P., Maddocks, A. and Gassert, F. (2013). World's 36 Most WaterStressed Countries, World Resources Institute.

http://www.wri.org/blog/2013/12/world\%E2\%80\%99s-36-most-waterstressed-countries Last accessed March 8, 2018.

[133] Robertson, C. (2009). Iraq Suffers as the Euphrates River Dwindles, The New-York Times.

http://topics.nytimes.com/topics/reference/timestopics/people/r/campbell_rob ertson/index.html?inline=nyt-per Last accessed January 20, 2018.

[134] Roger, P. and Lydon, P. (eds.). (1995). Water in the Arab World, Massachusetts, USA: Harvard University Press. University Press.

[135] Sadik, A.K. and Barghouti, S. (1995). The water problems of the Arab world: Management of scarce water resources. In P. Rogers and P. Lydon (eds.), Water in the Arab World. Massachusetts, USA: Harvard University Press, pp.4-37.

[136] Schaap, W. and Steenbergen, F. van. (2002). Ideas for Water Awareness Campaigns. Stockholm, Published by Global Water Partnership (GWP), Stockholm, Sweden

[137] Schmandt, J. and Kibaroglu, A. (2016). Sustainability of Engineered Rivers in Arid Lands. Policy Research Project Recent Submissions, Report 190. University of Texas Libraries.

https://repositories.lib.utexas.edu/handle/2152/16482 Last accessed March $15,2018$.

[138] Shahin, M. (2007). Water Resources and Hydrometorology of the Arab Region, Springer. The Netherlands, Dordrecht. ISBN-13 978-1-4020-4577-6

[139] Shams, S. (2006). Water conflict between Iraq and Turkey. ME News, http://www.mokarabat.com/m1091.htm

[140] Sharan, G., Jethava, K. and Shamante, A. (2005). Greenhouse Cultivation in a hot arid area. http://www.iimahd.ernet.in/publications/data/2005-01-06gsharan.pdf 
[141] Sissakian, V., Al-Ansari, N. and Knutsson, S. (2013). Sand and dust storm events in Iraq. Journal of Natural Science, 5(10), pp.1084-1094.

[142] Smakhtin, V., Revenga, C. and Döll, P. (2004). Taking into Account Environmental Water Requirements, Comprehensive Assessment Research Report 2, Comprehensive Assessment of Water Management in Agriculture. https://core.ac.uk/download/pdf/6405183.pdf Last accessed March 18, 2018.

[143] Stokes, E. (2016). The Drought That Preceded Syria's Civil War Was Likely the Worst in 900 Years. TIPPING POINT, March 3, 2016. Available at: https://news.vice.com/article/the-drought-that-preceded-syrias-civil-war-waslikely-the-worst-in-900-years. Last accessed March 13, 2018.

[144] Taylor and Francis Group (2003). The ME and North Africa, 49th Edition, Taylor and Francis, London. Available at: https://books.google.se/books?id=4CfBKvsiWeQC\&pg=PR3\&lpg=PR3\&dq $=$ taylor/francis+group.+2002.+the+middle+east+and+north+africa+2003.\&so urce=bl\&ots=Sg2I1qCBjN\&sig=vdePDEki0bnvzFlZ6pOu8MBWXJw\&hl=e n\&sa=X\&ved=0ahUKEwjNm4_GxbbZAhUG_KQKHW2jBtQQ6AEIKTAA $\# \mathrm{v}=$ onepage \&q=taylor\%2Ffrancis\%20group.\%202002.\%20the\%20middle\% 20east\%20and\%20north\%20africa\%202003.\&f=false Last accessed February, 2018.

[145] Texas Water Development Board (2010). Developing a Water Conservation Public Awareness Program: A Guide for Utilities. http://www.wateriq.org/texas-water/doc/Public_Awareness_UtilityGuide.pdf Last accessed March 12, 2018.

[146] Tomanbay, M. (2000). Turkey's Water Potential and the Southeast Anatolia Project, Chapter 6 of "Water Balance in the East Mediterranean", Brooks and Ozay (ed.). International Development Research Center, Ottawa, USA.

[147] Turan, I. (2004). Water and Turkish Foreign Policy, in Lenore, M.G. and Keridis, D., eds., The future of Turkish foreign policy. Cambridge, MA; MIT Press, 2004, pp.191-208.

[148] Turkish Ministry of Foreign Affairs (2012). Water Issues between Turkey, Syria and Iraq. Department of Transboundary Waters. http://sam.gov.tr/wpcontent/uploads/2012/01/WATER-ISSUES-BETWEEN-TURKEY-SYRIAAND-IRAQ.pdf. Last accessed January 12, 2018

[149] Unver, I. (1997). Southeastern Anatolia Project (GAP). International Journal of Water Resources Development, Vol. 13, No. 4, pp.453-484.

[150] UN Iraq, (2013). United Nations economic and social commission for western Asia. Bundesanstalt für Geowissenschaften und Rohstoffe. Inventory of Shared Water Resources in Western Asia, Beirut.

[151] United Nations (UN) (1976). Resources and Needs: Assessment of the World Water Situation, UN Water Conference, E/CONF:70/CPBI, New York, July 2, 1976, 10. 
[152] United Nations (UN) (1997). Convention on the Law of the NonNavigational Uses of International Watercourses, United Nations General Assembly, New York, A/RES/51/229, July 8, 1997.

[153] United Nations (UN) (2003). International Rivers and Lakes, A Newsletter prepared jointly by the Department for Economic and Social Affairs, United Nations, New York and the Economic Commission for Latin America and the Caribbean. Santiago, Chile, No. 39.

[154] United Nations (UN) (2010). Water Resources Management White Paper, United Nations Assistance Mission for Iraq, United Nations Country Team in Iraq, 20 p. http://iq.one.un.org/documents/100/white\%20paper-eng_Small.pdf Last accessed February 25, 2018.

[155] UN (2013). United Nations World Water Development Report 4. Volume 1: Managing Water under Uncertainty and Risk.

https://sustainabledevelopment.un.org/content/documents/404water.pdf Accessed March 18, 2018.

[156] United Nations and World Bank (2003). Joint Iraq Needs Assessment Working paper. October 2003.

http://siteresources.worldbank.org/IRFFI/Resources/Joint+Needs+Assessmen t.pdf. Accessed February 20, 2018.

[157] United Nations General Assembly (1997). Convention on the Law of the Non-Navigational Uses of International Watercourses, Official Records of the General Assembly, Fifty-first Session, Supplement No. 49 (A/51/49). Available at:

http://legal.un.org/ilc/texts/instruments/english/conventions/8_3_1997.pdf Lasted accessed March 18, 2018.

[158] UNDP (United Nations Development Program) (2011). Drought Impact Assessment, Recovery and Mitigation Framework and Regional Project Design in Kurdistan Region (KR), p.79. Available at: http://www.undp.org/content/dam/rbas/report/Drought.pdf last accessed February, 2018.

[159] UNEP (United Nations Environmental Program) (2003). Desk Study on the environment of Iraq. Switzerland, p.96.

[160] UN-ESCWA and BGR (2013). Inventory of Shared Water Resources in Western Asia, United Nations Economic and Social Commission for Western Asia and BundesanstaltfürGeowissenschaften und Rohstoffe, Beirut.

[161] US Department of State (1978). International Boundary Study: Iraq-Iran Boundary, Office of the Geographer, BIR. Available at:

http://www.parstimes.com/history/iran_iraq_boundary.pdf

Last accessed March 16, 2018.

[162] USAID (2017). Climate change risk profile, Iraq. Viewed 10/09/2020, https://www.climatelinks.org/sites/default/files/asset/document/2017Mar3_G EMS_Climate\%20Risk\%20Profile_Iraq_FINAL.pdf 
[163] Varela-Ortega, C. and Sagardoy, J.A. (2003). Analysis of Irrigation Water Policies in Syria: Current Developments and Future Options. Syrian agriculture at the crossroads. Fiorillo C. and Vercueil J.(eds.), FAO Agricultural Policy and Economic Development Series No. 8, DOI . 10.13140/2.1.4594.8485

[164] Venter, A. (2008). The Oldest Threat: Water in the ME, ME Policy, 6, 1, pp.126-136.

[165] Voss, K.A., Famiglietti, J.S., Lo, M.H., Linage, C., Rodell, M. and Swenson, S. (2013). Groundwater depletion in the ME from GRACE with implications for transboundary water management in the Tigris-EuphratesWestern Iran region. Water Resources Research, Vol.49, 2, pp.904-914.

[166] Wallas, C. (1998). Iran, Iraq still fail to bridge waterway dispute. Loss Angeles Times, August 1998. http://articles.latimes.com/1988-0819/news/mn-739_1_shatt-al-arab. Last accessed March 19, 2018.

[167] Waterbury, J. (1993). Transboundary water and the challenge of international cooperation in the ME, in Roger, R. and Lydon, P.(Ed.). Water in the Arab Word: Perspectives and Prognoses, Harvard University, pp.39-64.

[168] White, G.F. (1976). Introduction: World Trends and Needs. Natural Resources Journal, 16, 4, pp.737-741.

[169] Wikipedia (2017a). List of Dams and Reservoirs in Turkey / Southeastern Anatolia. Last edited on 18th Last Edited on June 18, 2017 https://en.wikipedia.org/wiki/List_of_dams_and_reservoirs_in_Turkey.

[170] Wikipedia (2017b). List of Dams and Reservoirs in Syria. Last edited on 9th June 2017. https://en.wikipedia.org/wiki/Category:Dams_in_Syria

[171] Wikipedia (2017c). List of dams and reservoirs in Iran. Last edited on 7th July 2017.

https://en.wikipedia.org/wiki/List_of_dams_and_reservoirs_in_Iran

[172] Wikipedia (2018). List of countries by future population (United Nations, medium fertility variant).

https://en.wikipedia.org/wiki/List_of_countries_by_future_population_(Unite d_Nations,_medium_fertility_variant)

[173] Wolf, A. T. and Newton, J. (2008). Case Study of Transboundary Dispute Resolution: the Tigris-Euphrates basin. Appendix: $\mathrm{C}$ of the book on Transboundary Dispute Resolution by the same authors. Oregon State University; Institute of water and watersheds 2008. Available at: https://www.researchgate.net/publication/237780392_Case_Study_Transbou ndary_Dispute_Resolution_the_Tigris-Euphrates_basin. Last accessed March 16, 2018.

[174] World Bank (2006). Iraq: Country Water Resources. Assistance Strategy: Addressing Major Threats to People's Livelihoods. Report No. 36297-IQ, p.97. 
[175] World Bank (2011). Damage and needs. Assessment of affected governorates viewed 5/09/2020.

http://documents1.worldbank.org/curated/en/600181520000498420/pdf/1236

31-REVISED-Iraq-Reconstruction-and-Investment-Part-2-Damage-and-

Needs-Assessment-of-Affected-Governorates.pdf

[176] Worldmeters (2018). Iran population. Available at

http://www.worldometers.info/world-population/iran-population/

[177] Worldmeters (2018). Iraq population. Available at

http://www.worldometers.info/world-population/iraq-population/

[178] Worldmeters (2018). Syria population. Available at

http://www.worldometers.info/world-population/syria-population/

[179] Worldmeters (2018). Turkey population. Available at

http://www.worldometers.info/world-population/turkey-population/

[180] Yuksel, I. (2012). South-Eastern Anatolia Project (GAP) factor and Energy Management in Turkey. Renewable Energy J., 39, pp.17-23.

[181] Zakaria, S., Al-Ansari, N. and Knutsson, S. (2013). Historical and future climatic change scenarios for temperature and rainfall for Iraq. Journal of Civil Engineering and Architecture, Vol. 7, pp.1574-1594.

[182] Zakaria, S., Mustafa, Y., Mohammed, D., Ali, S., Al-Ansari, N. and Knutsson, S. (2013). Estimation of annual harvested runoff at Sulaymaniyah Governorate, Kurdistan region of Iraq. Natural Science, 5, pp.1272-1283.

[183] Zakaria, S., Al-Ansari, N., Ezz-Aldeen, M. and Knutsson, S. (2012). Rainwater Harvesting At Eastern Sinjar Mountain, Iraq. Geoscience Research, 3 (2), pp.100-108.

[184] Zawahri, N. A. (2006). Stabilizing Iraq's Water Supply: What the Euphrates and Tigris Rivers Can Learn from the Indus. Third World Quarterly 27, 6, pp.1041-2058. 